\title{
Lower Gretaceous, Jurassic(?), and \\ Triassic Ostracoda From the \\ Atlantic Coastal Region
}

GEOLOGICAL SURVEY PROFESSIONAL PAPER 795

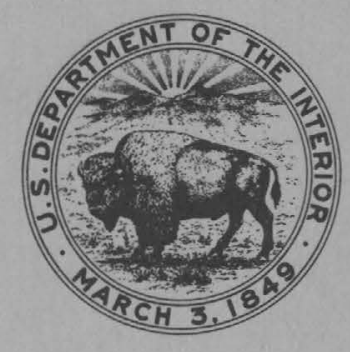





\section{Lower Cretaceous, Jurassic(?), and \\ Triassic Ostracoda From the Atlantic Coastal Region}

By FREDERICK M. SWAIN and PHILIP M. BROWN

GEOLOGICAL SURVEY PROFESSIONAL PAPER 795

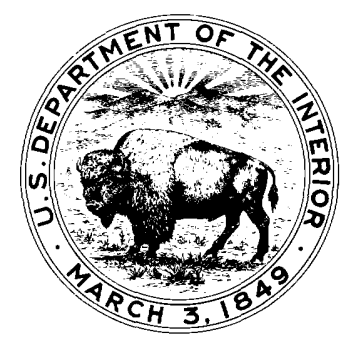

UNited STATES GOVERNMENT PRINTING OFFICE, WASHINGTON : 1972 


\section{UNITED STATES DEPARTMENT OF THE INTERIOR}

ROGERS C. B. MORTON, Secretary

\section{GEOLOGICAL SURVEY}

V. E. McKelvey, Director

Library of Congress catalog-card No. 72-600289

For sale by the Superintendent of Documents, U.S. Government Printing Office

Washington, D.C. 20402

Stock Number 2401-00250 


\section{CONTENTS}

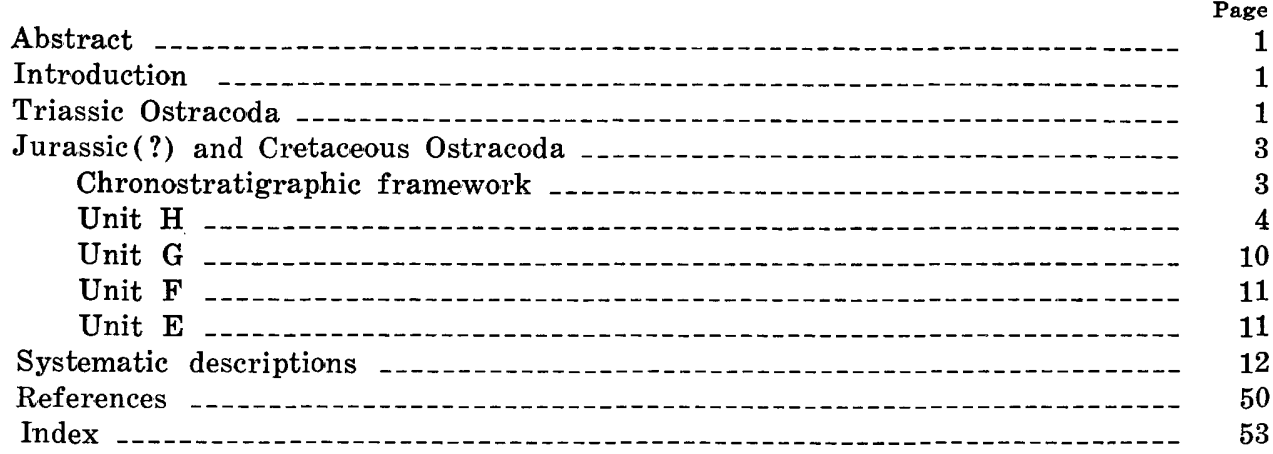

\section{ILLUSTRATIONS}

[Plates 1-9 follow index; plate 10 in pocket]

Plate 1. Darwinula, Darwinula? Cytherella, Paracypris, Potamocypris?, and Cypridea.

2. Darwinula? and Darwinula.

3. Cypridea, Monoceratina? Pseudobythocythere? Dolocytheridea, Dolocytheridea?, and Asciocythere?.

4. Asciocythere? and Asciocythere.

5. Asciocythere and Ovocytheridea?.

6. Fossocytheridea, Schuleridea, and Schuleridea?.

7. Schuleridea? Paraschuleridea, and Fabanella.

8. Metacytheropteron? Otocythere, Eocytheropteron, Eucytherura?, Juvenix, Hutsonia, and Hutsonia?.

9. Hutsonia, Protocythere, Protocythere? Cythereis, Klieana?, Taxodiella, Mandelstamia?, and Isocythereis?.

10. Correlation chart for the subsurface chronostratigraphic units of Jurassic(?) through Cretaceous age in the middle Atlantic States.

FigURe 1. Location map

2. Cypridea (C.) dequeenensis Swain and Brown

3. Darwinula rogersii (Jones)

4. Darwinula subquadrata Swain and Brown, n. sp

5. Darwinula? sp. 1

6. Darwinula? sp. 2 - Darwinula?

7. Darwinula? sp. 3 - Darwinula?

8. Darwinula? sp. 4

9. Monoceratina? sp _._.

10. Pseudobythocythere? sp -

11. Dolocytheridea? bosquetoidea Swain and Brown, n. sp

12. Asciocythere macropunctata Swain

13. Asciocythere? rugosa Swain and Brown, n. sp

14. Schuleridea hatterasensis Swain _- Sch

15. Schuleridea? sp 
FIGURE 16. Paraschuleridea postumbonata Swain and Brown, n. sp

17. Fabanella lanceolata (Swain)

18. Fabanella leguminoidea (Swain)

19. Fabanella sp _.....................

20. Metacytheropteron? bicostatum Swain and Brown, n. sp

21. Otocythere sp

22. Eucytherura? sp _.......

23. Juvenix sp -

24. Hutsonia blandoidea Swain and Brown, n. sp

25. Hutsonia collinsensis collinsensis Swain and Brown, n. sp., n. subsp

26. Hutsonia collinsensis attenuata Swain and Brown, n. subsp

27. Hutsonia collinsensis micropunctata Swain and Brown, n. subsp

28. Protocythere? sp

29. Klieana? sp

30. Cythereis cf. C. dentonensis Alexander

31. Isocythereis? $\mathrm{sp}$

32. Taxodiella sp

\section{TABLES}

TABLE 1. Stratigraphic distribution of the Mesozoic Ostracoda obtained from wells and described herein -----.--

2. Well number, location, date drilled, elevation, depth, and stratigraphic data for the 46 wells from which the Ostracoda were obtained 


\title{
LOWER CRETACEOUS, JURASSIC(?), AND TRIASSIC OSTRACODA
}

\section{FROM THE ATLANTIC COASTAL REGION}

\author{
By Frederick M. Swain and Philip M. Brown
}

\section{ABSTRACT}

This paper describes, lists the subsurface occurrence, and gives the stratigraphic distribution of 15 new species and subspecies, 24 taxa in open nomenclature, and 32 previously described, referable, or affinitive species of Ostracoda recovered from 46 recently drilled wells located in the Atlantic Coastal Plain of the United States. The Ostracoda occur chiefly in one or more of four letter-designated chronostratigraphic units that have been mapped in the subsurface. One chronostratigraphic unit (Unit $\mathrm{H}$ ) is Jurassic? and Cretaceous in age; two chronostratigraphic units (Unit G and Unit F) are Early Cretaceous in age; and one chronostratigraphic unit (Unit E) is Late Cretaceous in age. Also, this paper describes six species of Ostracoda, one of which is new, obtained from lacustrine shales of Late Triassic age at two exposures in east-central North Carolina. In all, 77 taxa of ostracodes are recorded in the collection described herein.

The following new species, new subspecies, and taxa in open nomenclature were recovered from chronostratigraphic units mapped in the subsurface: Cytherella spp. 1 and 2, Cypridea (C.) sp., Cypridea (C.) menevoides n. sp., Potamocypris? sp., Paracypris sp., Monoceratina? sp., Pseudobythocythere? sp., Dolocytheridea oertlii n. sp., Dolocytheridea? bosquetoidea n. sp., Asciocythere? rugosa n. sp., Asciocythere elongata n. sp., Ovocytheridea? sp., Schuleridea anterofossulata n. sp., Schuleridea? sp., Paraschuleridea twifordensis n. sp., Paraschuleridea postumbonata n. sp., Paraschuleridea curta n. sp., Fabanella sp., Metacytheropteron? bicostatum n. sp., Otocythere sp., Juvenix sp., Hutsonia collinsensis collinsensis n. sp., n. subsp., Hutsonia collinsensis attenuata n. subsp., Hutsonia collinsensis micropunctata n. subsp., Hutsonia collinsensis subsp., Hutsonia blandoidea n. sp., Hutsonia? sp., Protocythere? sp. 1, Protocythere? sp. 2, Klieana? sp., Cythereis sp., Isocythereis? sp., Eucytherura? sp., Mandelstamia? sp., and Taxodiella sp.

The following new species or taxa in open nomenclature were recovered from lacustrine shales of Triassic age that crop out in east-central North Carolina: Darwinula subquadrata n. sp., and Darwinula? spp. 1-4.

\section{INTRODUCTION}

Recently, a program of subsurface mapping was completed in that part of the Atlantic Coastal Plain which extends from Long Island, N.Y. through North Carolina. The purpose of the program was to establish and map permeability-distribution networks within the sedimentary mass. These networks will be used in evaluating the nature and potential of regional ground-water supplies. Paleontologic data, chiefly the occurrence and distribution of Ostracoda recovered from cores and cuttings, were used to help map nine Mesozoic and eight Cenozoic chronostratigraphic units in the subsurface. Various species of Ostracoda, many of which are new, were recognized to characterize each of the units.

In addition to listing the occurrence of some Ostracoda of Mesozoic age described previously, this report describes 15 new species and subspecies that occur chiefly in one or more of four of the chronostratigraphic units that have been mapped. These four chronostratigraphic units include one unit of Jurassic (?) and Cretaceous age, two units of Early Cretaceous age, and one unit of Late Cretaceous age. The Ostracoda were obtained from a group of 46 wells (fig. 1 and table 2). Most of the wells were drilled in connection with petroleum exploration. Also, this report describes six species of Ostracoda, one of which is new, that were obtained from the exposed Cumnock Formation (Newark Group) in the Deep River basin near Gulf, Chatham County, N.C., and, from undifferentiated sedimentary rocks of Late Triassic age in the Durham basin at an outcrop near Carpenter, Wake County, N.C. In all, 77 taxa are recorded in the collections described herein.

Stage names used in this report are from other sources.

\section{TRIASSIC OSTRACODA}

Collections of Upper Triassic fresh-water Ostracoda were obtained from two localities in east-central 


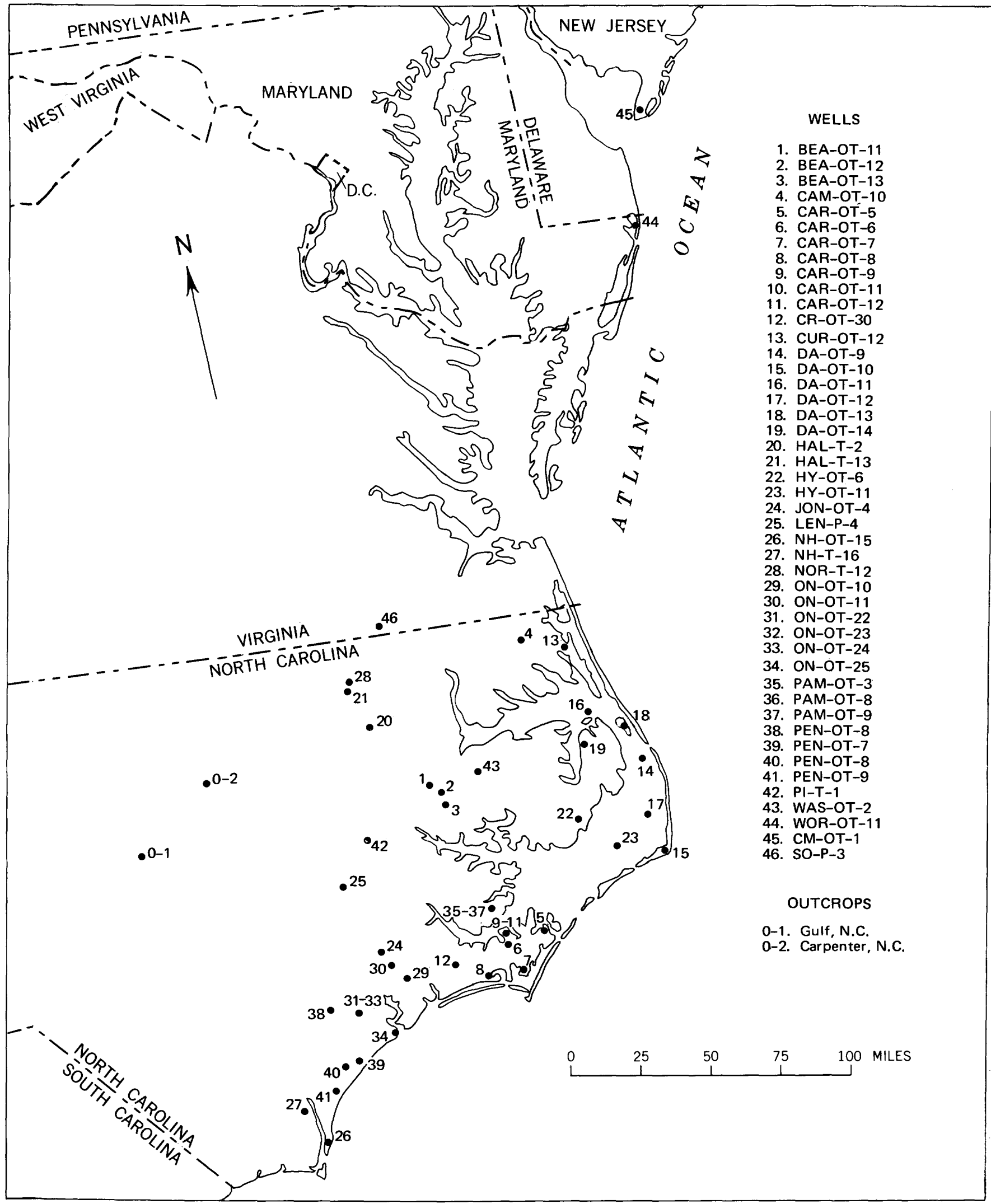

Figure 1.-Location map for the wells and outcrops from which the Mesozoic Ostracoda described herein were obtained. 
North Carolina; near Gulf in Chatham County and near Carpenter in Wake County.

Near Gulf, the Ostracoda were obtained from black shales in the Cumnock Formation (Newark Group) exposed in a highway borrow pit located just south of Bethany Baptist Church and east of the Town of Gulf water-treatment plant (fig. 1). The ostracode-bearing black shales are most prevalent in a drainage ditch that has developed on the floor of the pit.

Near Carpenter, the Ostracoda were obtained from red shales in undifferentiated deposits of Late Triassic age exposed in the main mine pit of the Triangle Brick Co. located several miles north of Carpenter, N.C., on State Highway 55 (fig. 1). The ostracode-bearing red shales and less commonly, red and mottled green shales, occur at several horizons in the pit. They appear to be most prevalent on the south side of the pit and in the lower third of the exposed section.

At both localities the Ostracoda are associated with numerous specimens of the conchostracan Howellites berryi Bock, 1953, and with abundant remains of plants and fish. Despite the fact that thousands of Ostracoda were obtained at each of the two localities, separation of specimens suitable for study was difficult. The shells are extremely fragile and are closely packed. Many were crushed during compaction of the shales. However, six species of Ostracoda were separated from the shales and are described herein.

The species of Darwinula described in this paper are similar to forms from the Late Permian (Ufmian and Tatarian Stages) of Russia and from the Early Triassic (Kashevarova, 1958). None of the strongly convex inequivalved fresh-water ostracodes of the Pennsylvanian and Permian deposits of West Virginia and Pennsylvania are represented in the present collection (for example, Gutschickia Scott, 1944; Whipplella Holland, 1934; Hilboldtina Scott and Summerson, 1943; and Pruvostina Scott and Summerson, 1943). Neither are ostracodes typical of fresh-water Jurassic deposits, such as Cypridea (C.) Bosquet, 1852, Bisulcocypris Pinto and Sanguinetti, 1958, and "Bairdiocypris" Kegel, 1932, present in the collection.

No definite correlation of the Triassic ostracode collection can be made with other known assemblages. The association of the ostracodes with the conchostracan Howellites berryi Bock, 1953, which is considered to be Late Triassic, is the basis for assignment of the present assemblage to that age.
Triassic Ostracoda or species having open nomen-

clature described herein are as follows:

Darivinula subquadrata Swain and Brown, n. sp.

Darwinula? spp. 1-4

Darwinula rogersii (Jones, 1862)

\section{JURASSIC(?) AND CRETACEOUS OSTRACODA}

\section{CHRONOSTRATIGRAPHIC FRAMEWORK}

A recently completed mapping program presented in a companion report by Brown, Miller, and Swain (1972) provides a chronostratigraphic framework that can be used to describe distribution of the Ostracoda obtained from wells and described herein. By means of 36 stratigraphic cross sections, that report presents a detailed analysis of the lithology encountered in the wells from which Ostracoda were recovered. Also, it designates type reference sections in the subsurface for each of the chronostratigraphic units in which the Ostracoda occur. For practical reasons, that report, which presents the chief results of the mapping program, should be used as a companion report in conjunction with this report. Throughout this report and especially in discussion of the occurrence of various species of Ostracoda, reference is made to a specific well located on a cross section shown on a plate in the companion report (for example, NC-DA-OT-12, section $Z^{\prime \prime}$ $Z^{\prime \prime \prime}$, pl. 51). Such reference negates the need to duplicate well sections in this report and, at the same time, provides access to a detailed analysis of the lithologic framework within which the Ostracoda described herein occur.

The Upper Jurassic(?) and Lower Cretaceous Ostracoda of the middle Atlantic States occur entirely in the subsurface. Several ostracode zones and biofacies can be recognized. The faunas represented include those that show a relation to the following:

1. Upper Jurassic (Kimmeridgian and PortlandianPurbeckian) beds represented in the Schuler Formation (Cotton Valley Group) of the La Casita Stage (Sabinasian) in the Gulf region.

2. Lower Cretaceous (Neocomian and lower Aptian) strata that are typical of the Durango and Nuevo León Stages (Coahuilan) in the Gulf region.

3. Lower Cretaceous (upper Aptian and lower Albian) strata that are typical of the Trinity Stage (Comanchean) in the Gulf region.

4. Lower Cretaceous (upper Albian and lower Cenomanian) strata that are typical of the Fredericksburg and Washita Stages (Comanchean) in the Gulf region. 
During the mapping program and within the Jurassic (?) through Cretaceous segment of the depositional sequence, it was recognized that the physical change reflected in rocks of the Atlantic region was out of phase with the physical change reflected in rocks of the Gulf region. Because Mesozoic chronostratigraphic boundaries, when extended from the Gulf region, often do not coincide with physical changes in rocks of the Atlantic region, we did not, for practical purposes, apply the Mesozoic stage terms of the Gulf region to the Atlantic sequence. Instead, we proposed and adopted an informal open-end classification for rocks of Mesozoic age in the subsurface of the Atlantic region. It consists of letter designations ( $I$ to $A$ ) for nine regional geologic sequences that range in age from Jurassic (?) through Late Cretaceous. These letterdesignated sequences constitute informal chronostratigraphic units of regional extent. They exhibit lithologies judged to be of the same age. In general, the boundaries of these units coincide with the boundaries of depositional sequences recognized in the subsurface in the Atlantic region.

The Jurassic(?) through Cretaceous segment of the chronostratigraphic framework established in the companion report, is reproduced as plate 10 in this report. The general relation that we recognize between the provincial stage terms of the Gulf region and the informal chronostratigraphic terms of the Atlantic region is shown on plate 10 .

The Ostracoda obtained from wells and described herein occur principally in one or more of four of the chronostratigraphic units mapped-Unit $H$, Unit G, Unit F, and Unit E. (See table 1 and $\mathrm{pl}$. 10.) Several of the species also occur occasionally in Unit D and Unit C. The stratigraphic distribution of Ostracoda from the subsurface collections described herein is shown in table 1. The location, total depth, and stratigraphic data for the wells from which the Ostracoda were recovered are given in table 2. The stratigraphic data given for each well include the depth to the top of Unit $\mathrm{H}$, Unit $\mathrm{G}$, Unit $\mathrm{F}$, and Unit $\mathrm{E}$ and the thickness of each unit, if these units were present in the well.

Following is a brief summary description of these four chronostratigraphic units, a listing of the new species recovered from each unit, and a listing of species described previously from beds now included in each unit.

\section{UNIT H}

The strata of Unit $\mathrm{H}$ are predominantly marine to marginal marine in eastern North Carolina; there the unit consists of a lower limy section, a middle clastic section, and an upper limy section. In
Virginia and northward into New Jersey, the strata of Unit $\mathrm{H}$ are chiefly nonmarine, except locally in areas adjacent to the present coast; in coastal areas, the unit consists of fine- to coarse-grained sand, commonly feldspathic, interbedded with varicolored shales which are chiefly red and brown.

The designated type reference section for Unit $\mathrm{H}$ is in a well (NC-HY-OT-11, table 2) located in Hyde County, N.C. The reference section is 1,120 feet thick (NC-HY-OT-11, section $Z^{\prime}-Z^{\prime \prime}$, pl. $50)$ and is the lithologic interval between the depths of 6,116 and 7,236 feet. In the subsurface Unit $H$ attains a maximum measured thickness of 2,072 feet in a well (MD-WOR-OT-11, table 2) in Worcester County, Md. (MD-WOR-OT-11, section $M-M^{\prime}$, pl. 35).

Unit $\mathrm{H}$ is judged to include rocks of late Sabinasian (?), Coahuilan, and early Comanchean Ages. It is correlative with the upper part of the La Casita (?) Stage, with the Durango Stage and the Nuevo León Stage, and with the lower part of the Trinity Stage and their typical strata in the Gulf region (pl. 10).

Both marine and nonmarine Ostracoda have been recovered from Unit $\mathrm{H}$. The Ostracoda occur chiefly in the upper and middle part of the unit and rarely in its lower part. Ostracode species recovered from Unit $\mathrm{H}$ are listed in table 1 . The new or open species and subspecies described herein are as follows:

Cypridea (C.) sp.

Cypridea (C.) menevoides Swain and Brown, n. sp.

Potamocypris? sp.

*Paracypris sp.

*Paraschuleridea twifordensis Swain and Brown, n. sp.

Paraschuleridea curta Swain and Brown, n. sp.

*Metacytheropteron? bicostatum Swain and Brown, n. sp. Otocythere sp.

Juvenix sp.

*Hutsonia collinsensis collinsensis Swain and Brown, n. sp., n. subsp.

*Hutsonia collinsensis attenuata Swain and Brown, n. subsp.

*Hutsonia collinsensis micropunctata Swain and Brown, n. subsp.

*Hutsonia collinsensis subsp.

*Hutsonia blandoidea Swain and Brown, n. sp.

Hutsonia sp.

Taxodiella sp.

Species marked with an asterisk also occur in one or more of the other chronostratigraphic units recognized in the middle Atlantic States. (See table 1.)

The genera Otocythere and Taxodiella have not been reported previously from the United States but have been reported from Asia or Europe.

Previously, Swain (1952) identified the following species from beds now included in Unit $\mathrm{H}$ : 
TABLE 1.-Stratigraphic distribution of the Mesozoic Ostracoda obtained from wells and described herein

\begin{tabular}{|c|c|c|c|c|c|c|c|}
\hline \multirow{2}{*}{ Species } & \multicolumn{6}{|c|}{$\begin{array}{l}\text { Occurrence in the } \\
\text { Middle Atlantic States }\end{array}$} & \multirow{2}{*}{ Occurrence elsewhere } \\
\hline & $\underset{\mathbf{H}}{\text { Unit }}$ & $\underset{G}{\text { Unit }}$ & $\underset{\mathbf{F}}{\text { Unit }}$ & $\underset{\mathbf{E}}{\text { Unit }}$ & $\underset{\mathrm{D}}{\text { Unit }}$ & $\underset{\mathrm{C}}{\text { Unit }}$ & \\
\hline Cytherella sp. 1 & ----- & ------ & $-\ldots-n$ & $\times$ & $\ldots \ldots$ & - & \\
\hline Cytherella ef. C. ovata (Roemer) & ----- & ----- & $x$ & $-\ldots-$ & $-\ldots-\ldots$ & $-\ldots-$ & Albian-Senonian, Europe. \\
\hline Cytherella sp. 2 & $-\cdots--$ & x & ----- & $--\cdots$ & ----- & ----- & \\
\hline Cypridea (C.) diminuta Vanderpool & ----- & $x$ & & $---\cdots$ & ----- & ----- & Trinitian, Arkansas. \\
\hline Cypridea (C.) wyomingensis Jones _- & $\times$ & $x$ & ------ & ----- & ----- & ---- & $\begin{array}{l}\text { Trinitian, Arkansas; Bear River Formation, } \\
\text { Wyoming; Upper Jurassic, Arkansas. }\end{array}$ \\
\hline Cypridea (C.) dequeenensis Swain and Brown & $x$ & $-\ldots--$ & ----- & ---- & ----- & ----- & Trinitian, Arkansas. \\
\hline Cypridea (C.) sp & $\times$ & $--\cdots--$ & ---- & ------ & ----- & ----- & \\
\hline Cypridea (C.) menevoides Swain and Brown n. sp & $x$ & $-\ldots-\ldots$ & -...-- & ------ & ----- & ----- & \\
\hline Potamucypris? sp & $x$ & $\ldots-\ldots$ & $-\ldots-n$ & ----- & ----- & ----- & \\
\hline Paracypris goodlandensis Howe and Laurencich & ----- & ----- & $x$ & $-\ldots-1$ & -...- & $-\cdots-$ & Lower part of Atkinson Formation, Georgia. \\
\hline Paracypris sp & $\times$ & $\times$ & ----- & $--\cdots-$ & ---- & $-\cdots--$ & \\
\hline Monoceratina? sp & ----- & $x$ & ---- & ----- & ----- & ----- & \\
\hline Pseudobythocythere? sp & ------ & $\times$ & ----- & ---- & ---- & ---- & \\
\hline Dolocytheridea? bosquetoidea Swain and Brown, n. sp - & ----- & $x$ & $\times$ & $\times$ & ----- & ----- & \\
\hline Dolocytheridea oertlii Swain and Brown, n. sp. & ----- & $x$ & $x$ & $x$ & ----- & ----- & \\
\hline Asciocythere triangularis Swain & ----- & $x$ & ---- & ----- & ---- & ----- & \\
\hline Asciocythere elongata Swain and Brown, n. sp & ----- & $x$ & $\times$ & $---n$ & ----- & ----- & \\
\hline Asciocythere? rugosa Swain and Brown, n. sp & ----- & $x$ & ----- & ----- & ----- & ----- & \\
\hline Asciocythere rotunda (Vanderpool) & ----- & $\times$ & $\times ?$ & ----- & ------ & ----- & Trinitian, Arkansas. \\
\hline Ascicocythere macropunctata Swain & ----- & ----- & $x$ & $x$ & $\times$ & $\times$ & \\
\hline Ovocytheridea? $\mathrm{sp}$ & ------ & $\times$ & 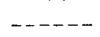 & $-\cdots$ & ----- & ------ & \\
\hline Fossocytheridea lenoirensis Swain and Brown & ----- & ----- & $x$ & -.--- & ----- & $\times ?$ & \\
\hline Perissocytheridea odomensis Swain and Brown & ------ & ------ & $x$ & ----- & $\times$ & ---- & \\
\hline Schuleridea anterofossulata Swain and Brown, n. sp --_-- & ----- & $\times$ & $-\ldots-$ & $-\ldots-\ldots$ & ----- & ----- & \\
\hline Schuleridea? sp & ------ & ------ & $-\cdots--$ & $\times$ & ------ & ----- & \\
\hline Schuleridea? lacustris Swain & $\times$ & $\times$ & ----- & $----\infty$ & ------ & ----- & \\
\hline Schuleridea hatterasensis Swain & $x$ & $x$ & ----- & $-\cdots--$ & $--\cdots$ & $-\ldots-n$ & \\
\hline Paraschuleridea twifordensis Swain and Brown, n. sp ---- & $\times$ & $x$ & ---- & ------ & ----- & ----- & \\
\hline Paraschuleridea postumbonata Swain and Brown, n. sp --- & ------ & $x$ & ----- & ---- & ----- & ----- & \\
\hline Paraschuleridea curta Swain and Brown, n. sp & x & $-\ldots--$ & ----- & ------ & ----- & ----- & \\
\hline Fabanella sp & ----- & $x$ & ----- & ----- & ------ & ----- & \\
\hline Fabanella tumidosa (Swain) & x & $x$ & $-\cdots-$ & ----- & ----- & $\ldots---$ & \\
\hline Fabanella lanceolata (Swain) & ------ & $\times$ & ----- & ------ & ----- & ------ & \\
\hline Fabanella leguminoidea (Swain) & ----- & x & ----- & ----- & ----- & ------ & \\
\hline Eucythere semiglypta Swain and Brown & $---\ldots$ & ----- & $\times$ & ------ & ----- & ----- & \\
\hline Metacytheropteron? bicostatum Swain and Brown, n. sp -- & $\times$ & ----- & $x$ & ------ & ----- & $-\infty--$ & \\
\hline Otocythere sp & $\times$ & $-\cdots--$ & $---\cdots$ & ----- & ---- & $----n$ & \\
\hline Orthonotacythere delicatula Swain and Brown & ----- & ----- & $\times$ & $x$ & $\times$ & ----- & \\
\hline Eocytheropteron tumoides (Swain) & $\ldots--\cdots$ & $x^{\prime}$ & ----- & ----- & ----- & ------ & \\
\hline Eocytheropteron venoides Swain and Brown & ----- & ------ & x & ----- & x & ------ & \\
\hline Eocytheropteron trinitiensis (Vanderpool) & $-\ldots-\ldots$ & $x$ & - - - - - & ----- & ----- & ----- & Trinitian, Arkansas. \\
\hline Eocytheropteron tumidum (Alexander) & 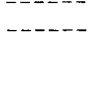 & ---- & $\times$ & ----- & ----- & ----- & $\begin{array}{l}\text { Lower part of Atkinson Formation, Florida; } \\
\text { Goodland and Kiamichi Formations, Texas } \\
\text { and Louisiana. }\end{array}$ \\
\hline Eucytherura sp - & $-\cdots-1$ & ------ & $x$ & ----- & ------ & ----- & \\
\hline Juvenix sp & $\times$ & ----- & ----- & ----- & ---- & ------ & \\
\hline Centrocythere annulopapillata Swain and Brown & ------ & $-\cdots-\cdots$ & $\times$ & $\times$ & ----- & ----- & $\begin{array}{l}\text { Lower part of Atkinson Formation, Florida } \\
\text { and Georgia. }\end{array}$ \\
\hline $\begin{array}{l}\text { Hutsonia collinsensis collinsensis Swain and Brown, n. sp., } \\
\text { n. subsp. }\end{array}$ & $x$ & $x$ & ---- & ----- & ----- & ----- & \\
\hline Hutsonia collinsensis attenuata Swain and Brown, n. subsp. & $x$ & $\times$ & ------ & ----- & ----- & ----- & \\
\hline $\begin{array}{l}\text { Hutsonia collinsensis micropunetata Swain and Brown, } n \text {. } \\
\text { subsp. }\end{array}$ & $x$ & $\times$ & ---- & ----- & $----\infty$ & ---- & \\
\hline Hutsonia collinsensis subsp & $x$ & $x$ & ----- & ----- & ----- & ------ & \\
\hline Hutsonia blandoidea Swain and Brown, n. sp & $x$ & $x$ & $-\cdots-\infty$ & ----- & ----- & $-\ldots-$ & \\
\hline Hutsonia sp & $\times$ & ---- & $-\ldots-$ & 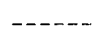 & ----- & ---- & \\
\hline Hutsonia? ef. H.? microrugosa Swain & $x$ & $\times$ & ----- & ----- & ----- & $-\infty---$ & \\
\hline Protocythere? sp. 1 & ----- & ----- & $\times$ & ----- & ----- & ----- & \\
\hline Protocythere sp. aff. $P$. inornata Kaye & ------ & $\times$ & ---- & ------ & $-\cdots--$ & ----- & \\
\hline Protocythere aff. P. aptensis Oertli & $\times$ & $x$ & $\times$ & ----- & ----- & ------ & \\
\hline Protocythere? sp. 2 & ----- & $x$ & ----- & ---- & $-\cdots--$ & ----- & \\
\hline Klieana? sp & ----- & $\times$ & ----- & ---- & ----- & ----- & \\
\hline Cythereis ef. $C$. dentonensis Alexander & ----- & ---- & $\times$ & ----- & $---\cdots$ & ---- & \\
\hline Cythereis sp & ---- & $\times$ & ----- & ----- & ----- & ----- & \\
\hline Cythereis sp. aff. C. lamplughi Kaye & ----- & $x$ & ------ & ----- & ----- & ----- & \\
\hline Cythereis praeornata Swain and Brown & $-\ldots-1$ & $x$ & ----- & ----1 & ----- & ----- & Trinitian, Arkansas and Texas. \\
\hline Isocythereis? sp & ----- & $x$ & 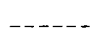 & ----- & ----- & ----- & \\
\hline Mandelstamia? sp & ------ & $x$ & ------ & ------ & ----- & $-\ldots-\ldots$ & \\
\hline Taxodiella sp - & $\times$ & ----- & ---- & ----- & ----- & $-\ldots--$ & \\
\hline $\begin{array}{l}\text { Hutsonia? sp., immature (introduced for comparison; not } \\
\text { found in study area). }\end{array}$ & ----- & $---\cdots$ & ----- & ---- & ----- & $-\cdots--$ & $\begin{array}{l}\text { Schuler Formation, Upper Jurassic, } \\
\text { Louisiana. }\end{array}$ \\
\hline
\end{tabular}


TABLE 2.-Well number, location, date drilled, elevation, depth, and

Cross-section well Name of Well
No.

Coordinate
location

Date drilled

(Letters refer to State, County, type of well, and project number. See Prof. Paper 796, p. 35)

Beaufort

$35^{\circ} 38^{\prime} 15^{\prime \prime} \quad 76^{\circ} 51^{\prime} 15^{\prime \prime}$

$35^{\circ} 35^{\prime} 45^{\prime \prime} \quad 76^{\circ} 48^{\prime} 10^{\prime \prime}$

$35^{\circ} 32^{\prime} 45^{\prime \prime} \quad 76^{\circ} 46^{\prime} 45^{\prime \prime}$

Aug. 1963

Aug. 1963

Aug. 1963

Zeno Ratcliff No. 1 .

Rodman No. 1.
E. F. Blair \& Assoc.
Weyerhauser No. 1 $36^{\circ} 24^{\prime} 40^{\prime \prime}$

Sept. 1965 _. 16

Elevation
of well

(feet above

sea level)
Total depth of well

\begin{tabular}{|c|c|c|c|c|c|c|}
\hline $\mathrm{NC}-\mathrm{CAM}-\mathrm{OT}-10$ & $\begin{array}{l}\text { E. F. Blair \& Assoc. } \\
\text { Weyerhauser No. } 1\end{array}$ & $36^{\circ} 24^{\prime} 40^{\prime \prime}$ & $76^{\circ} 10^{\prime} 30^{\prime \prime}$ & Sept. $1965 \quad \ldots-\ldots----$ & 16 & 3,741 \\
\hline & & & & & & Carteret \\
\hline NC-CAR-OT-5 _- & $\begin{array}{c}\text { Coastal Plains Oil Co., } \\
\text { Bayland No. }\end{array}$ & $34^{\circ} 53^{\prime} 55^{\prime \prime}$ & $76^{\circ} 22^{\prime} 00^{\prime \prime}$ & Oct. 1961 & 18 & 5.609 \\
\hline $\mathrm{NC}-\mathrm{CAR}-\mathrm{OT}-6 \quad-\ldots$ & $\begin{array}{l}\text { Coastal Plains Oil Co., } \\
\text { Yeatman No. } 1 .\end{array}$ & $34^{\circ} 54^{\prime} 30^{\prime \prime}$ & $76^{\circ} 37^{\prime} 30^{\prime \prime}$ & Sept. 1961 & 20 & 4,096 \\
\hline $\mathrm{NC}-\mathrm{CAR}-\mathrm{OT}-7 \quad \ldots$ & $\begin{array}{l}\text { Coastal Plains Oil Co., } \\
\text { Hunt!ey-Davis No. } 1 .\end{array}$ & $34^{\circ} 43^{\prime} 50^{\prime \prime}$ & $76^{\circ} 34^{\prime} 30^{\prime \prime}$ & Oct. 1961 & 20 & 4,945 \\
\hline $\mathrm{NC}-\mathrm{CAR}-\mathrm{OT}-8$ & $\begin{array}{l}\text { F. L. Karston } \\
\text { Laughton No. } 1 .\end{array}$ & $34^{\circ} 45^{\prime} 40^{\prime \prime}$ & $76^{\circ} 43^{\prime} 30^{\prime \prime}$ & May 1945 & 19 & 4,044 \\
\hline $\mathrm{NC}-\mathrm{CAR}-\mathrm{OT}-9$ & $\begin{array}{l}\text { Carolina Petroleum Co., } \\
\text { D. L. Phillips No. } 1 .\end{array}$ & $34^{\circ} 58^{\prime} 50^{\prime \prime}$ & $76^{\circ} 39^{\prime} 00^{\prime \prime}$ & Sept. 1947 --- & 12 & 3,964 \\
\hline $\mathrm{NC}-\mathrm{CAR}-\mathrm{OT}-11 \quad \ldots$ & Carolina Petroleum Co., & $34^{\circ} 57^{\prime} 05^{\prime \prime}$ & $76^{\circ} 38^{\prime} 30^{\prime \prime}$ & July 1946 _- & 16 & 4,069 \\
\hline \multirow[t]{2}{*}{$\mathrm{NC}-\mathrm{CAR}-\mathrm{OT}-12$} & $\begin{array}{l}\text { Carolina Petroleum Co., } \\
\text { John Wallace No. } 1 .\end{array}$ & $34^{\circ} 58^{\prime} 45^{\prime \prime}$ & $76^{\circ} 38^{\prime} 00^{\prime \prime}$ & Dec. 1946 _ & 13 & 4,024 \\
\hline & & & & & & Craven \\
\hline \multirow[t]{2}{*}{$\mathrm{NC}-\mathrm{CR}-\mathrm{OT}-30$} & $\begin{array}{l}\text { Carolina Petroleum Co., } \\
\text { Charles Bryan No. } 1 .\end{array}$ & $34^{\circ} 50^{\prime} 55^{\prime \prime}$ & $76^{\circ} 57^{\prime} 45^{\prime \prime}$ & Jan. $1947 \ldots$ & 41 & 2,435 \\
\hline & & & & & & Currituck \\
\hline \multirow[t]{2}{*}{$\mathrm{NC}-\mathrm{CUR}-\mathrm{OT}-12$} & $\begin{array}{l}\text { E. F. B'air \& Assoc., } \\
\text { Twiford No. } 1 .\end{array}$ & $36^{\circ} 18^{\prime} 10^{\prime \prime}$ & $75^{\circ} 55^{\prime} 30^{\prime \prime}$ & Oct. 1965 & 12 & 4,553 \\
\hline & & & & & & Dare \\
\hline NC-DA-OT-9 & $\begin{array}{l}\text { Standard Oil Co. of N. J. } \\
\text { N. C. Esso No. } 2 .\end{array}$ & $35^{\circ} 42^{\prime} 12^{\prime \prime}$ & $75^{\circ} 35^{\prime} 54^{\prime \prime}$ & March 1947 _. & 21 & 6,410 \\
\hline NC-DA-OT-10 & $\begin{array}{l}\text { Standard Oil Co. of N. J. } \\
\text { Hatteras Light No. }\end{array}$ & $35^{\circ} 15^{\prime} 00^{\prime \prime}$ & $75^{\circ} 31^{\prime} 45^{\prime \prime}$ & Feb.-July 1946 & 25 & 10,044 \\
\hline NC-DA-OT-11 & $\begin{array}{l}\text { Socony-Mobil Oil Co. } \\
\text { State of N. C. No }\end{array}$ & $35^{\circ} 59^{\prime} 55^{\prime \prime}$ & $75^{\circ} 52^{\prime} 00^{\prime \prime}$ & July 1965 & 24 & 5,269 \\
\hline $\mathrm{NC}-\mathrm{DA}-\mathrm{OT}-12$ & $\begin{array}{l}\text { Socony-Mobil Oil Co. } \\
\text { State of N. C. No. } 2 .\end{array}$ & $35^{\circ} 26^{\prime} 20^{\prime \prime}$ & $75^{\circ} 34^{\prime} 35^{\prime \prime}$ & July 1965 & 24 & 8,386 \\
\hline NC-DA-OT-13 & E. F. Blair \& Assoc. & $35^{\circ} 53^{\prime} 00^{\prime \prime}$ & $75^{\circ} 40^{\prime} 15^{\prime \prime}$ & Nov. 1965 & 13 & 6,295 \\
\hline $\mathrm{NC}-\mathrm{DA}-\mathrm{OT}-14$ & $\begin{array}{l}\text { E. F. Blair \& Assoc. } \\
\text { W. Va. Pulp \& Paper No. } 1 .\end{array}$ & $35^{\circ} 51^{\prime} 50^{\prime \prime}$ & $75^{\circ} 55^{\prime} 30^{\prime \prime}$ & Dec. 1965 & 11 & 5,147 \\
\hline
\end{tabular}

Halifax

\begin{tabular}{|c|c|c|c|c|c|c|}
\hline $\begin{array}{l}\text { NC-HAL-T-2 } \\
\text { NC-HAL-T-13 }\end{array}$ & $\begin{array}{l}\text { Town of Scot'and Neck } \\
\text { USGS test well No. 2, } \\
\text { Caledonia Prison Farm. }\end{array}$ & $\begin{array}{l}36^{\circ} 06^{\prime} 55^{\prime \prime} \\
36^{\circ} 18^{\prime} 35^{\prime \prime}\end{array}$ & $\begin{array}{l}77^{\circ} 22^{\prime} 35^{\prime \prime} \\
77^{\circ} 26^{\prime} 50^{\prime \prime}\end{array}$ & $\begin{array}{l}\text { March } 1962 \ldots- \\
1961\end{array}$ & $\begin{array}{r}93 \\
\pm 60\end{array}$ & $\begin{array}{l}338 \\
\mathbf{2 3 6}\end{array}$ \\
\hline & & & & & & Hyde \\
\hline $\mathrm{NC}-\mathrm{HY}-\mathrm{OT}-6 \quad \ldots$ & E. F. Blair \& Assoc. & $35^{\circ} 27^{\prime} 25^{\prime \prime}$ & $76^{\circ} 01^{\prime} 50^{\prime \prime}$ & Dec. $1965 \quad \ldots$ & 10 & 5,570 \\
\hline \multirow[t]{2}{*}{$\mathrm{NC}-\mathrm{HY}-\mathrm{OT}-11$} & $\begin{array}{l}\text { Octavius Ballance No. } 1 . \\
\text { Socony-Mobil Oil Co. } \\
\text { State of N. C. No. } 3 .\end{array}$ & $35^{\circ} 18^{\prime} 25^{\prime \prime}$ & $75^{\circ} 49^{\prime} 45^{\prime \prime}$ & Aug. 1965 & 24 & 7,314 \\
\hline & & & & & & Jones \\
\hline \multirow[t]{2}{*}{ NC-JON-OT-4 _- } & $\begin{array}{l}\text { P. Henderson, } \\
\text { Hoffman Forest. }\end{array}$ & $34^{\circ} 56^{\prime} 15^{\prime \prime}$ & $77^{\circ} 24^{\prime} 30^{\prime \prime}$ & June $1960 \ldots$ & \pm 50 & 1,218 \\
\hline & & & & & & Lenoir \\
\hline \multirow[t]{2}{*}{$\mathrm{NC}-\mathrm{LEN}-\mathrm{P}-4$} & DuPont No. 6 & $35^{\circ} 21^{\prime} 25^{\prime \prime}$ & $77^{\circ} 27^{\prime} 25^{\prime \prime}$ & $1955 \quad \ldots-\ldots \ldots \ldots$ & 53 & 823 \\
\hline & & & & & & New Hanover \\
\hline $\mathrm{NC}-\mathrm{NH}-\mathrm{OT}-15 \ldots$ & $\begin{array}{l}\text { N. C. Oil \& Gas Co. } \\
\text { Fort Fisher No. } 1 .\end{array}$ & $33^{\circ} 58^{\prime} 25^{\prime \prime}$ & $77^{\circ} 55^{\prime} 10^{\prime \prime}$ & Sept. $1966 \ldots$ & 9 & 1,558 \\
\hline NC-NH-T-16 & $\begin{array}{l}\text { Hercules Powder Co., No. } 1 \\
\text { observation well. }\end{array}$ & $34^{\circ} 18^{\prime} 15^{\prime \prime}$ & $77^{\circ} 58^{\prime} 30^{\prime \prime}$ & March 1967 & 5 & 1,080 \\
\hline
\end{tabular}


stratigraphic data for the 46 wells from which the Ostracoda were obtained

\begin{tabular}{|c|c|c|c|c|c|c|c|c|}
\hline \multicolumn{2}{|c|}{ Unit $\mathbf{H}$} & \multicolumn{2}{|c|}{ Unit $\mathbf{G}$} & \multicolumn{2}{|c|}{ Unit $\mathbf{F}$} & \multicolumn{2}{|c|}{ Unit $\mathrm{E}$} & \multirow[b]{2}{*}{$\begin{array}{l}\text { Reference cross sections and plates in companion } \\
\text { report by Brown, Miller, and Swain (1972) }\end{array}$} \\
\hline $\begin{array}{l}\text { Depth of } \\
\text { top below } \\
\text { land surface } \\
\text { (feet) }\end{array}$ & $\begin{array}{c}\text { Thickness } \\
(T) \text { or } \\
\text { thickness } \\
\text { penetrated } \\
(P) \\
\text { (feet) }\end{array}$ & $\begin{array}{l}\text { Depth of top } \\
\text { below land } \\
\text { surface } \\
\text { (feet) }\end{array}$ & $\begin{array}{l}\text { Thickness } \\
(T) \text { or } \\
\text { thickness } \\
\text { penetrated } \\
(P) \text { (feet) }\end{array}$ & $\begin{array}{l}\text { Depth of top } \\
\text { be ow land } \\
\text { surface } \\
\text { (feet) }\end{array}$ & $\begin{array}{l}\text { Thickness } \\
\text { (T) or } \\
\text { thickness } \\
\text { penetrated } \\
(P) \text { (feet) }\end{array}$ & $\begin{array}{l}\text { Depth of top } \\
\text { below land } \\
\text { surface } \\
\text { (feet) }\end{array}$ & $\begin{array}{c}\text { Thickness } \\
(T) \text { or } \\
\text { thickness } \\
\text { penetrated } \\
(P) \text { (feet) }\end{array}$ & \\
\hline
\end{tabular}

County, N.C.

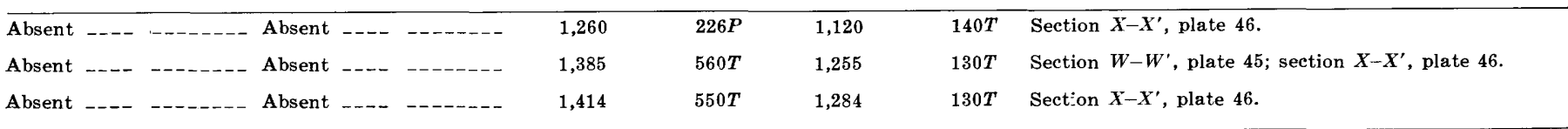

County, N.C.

\begin{tabular}{|c|c|c|c|c|c|c|c|c|}
\hline 2,602 & $212 T$ & 2,226 & $376 T$ & 1,324 & $902 T$ & 1,152 & $172 T$ & Section $W-W^{\prime}$, plate $45 ;$ section $J-J^{\prime}$, plate 32 \\
\hline \multicolumn{9}{|c|}{ County, N.C. } \\
\hline 5,034 & $518 T$ & 4,092 & $942 T$ & 3,334 & $758 T$ & 2,950 & $384 T$ & Section $E-E^{\prime}$, plate 27 ; section $\mathrm{Z}^{\prime}-\mathrm{Z}^{\prime}$, plate 50. \\
\hline 3,990 & $86 P$ & 3,295 & $695 T$ & 2,750 & $545 T$ & 2,450 & $300 T$ & Section $X-X^{\prime}$, plate 46 ; section $Z^{\prime}-Z^{\prime}$, plate 50. \\
\hline 4,600 & $338 T$ & 3,670 & $930 T$ & 3,195 & $475 T$ & 2,800 & $395 T$ & $\begin{array}{l}\text { Section } D-D^{\prime} \text {, plate } 26 \text {; section } X-X^{\prime} \text {, plate } 46 \text {; sec- } \\
\text { tion } Y-Y^{\prime} \text {, plate } 47 \text {; section } Z-Z^{\prime} \text {, plate } 49 \text {; sec- } \\
\text { tion } Z^{\prime}-Z^{\prime} \text {, plate } 50 \text {. }\end{array}$ \\
\hline 3,931 & $80 T$ & 3,214 & $717 T$ & 2,711 & $503 T$ & 2,421 & $290 T$ & Section $D-D^{\prime}$, plate 26 ; section $\mathrm{Z}-\mathrm{Z}^{\prime}$, plate 49 \\
\hline 3,701 & $232 T$ & 3,173 & $528 T$ & 2,593 & $580 T$ & 2,296 & $297 T$ & Section $X-X^{\prime}$, plate 46 \\
\hline 3,798 & $246 T$ & 3,249 & $\mathbf{5 4 9 T}$ & 2,642 & $607 T$ & 2,354 & $288 T$ & Section $X-X^{\prime}$, plate 46 ; section $Z^{\prime}-Z^{\prime}$, plate 50. \\
\hline 3,759 & $246 T$ & 3,209 & $550 T$ & 2,601 & $608 T$ & 2,317 & $284 T$ & Section $E-E^{\prime}$, plate 27 ; section $Y^{\prime}-Y^{\prime} '$, plate 48 . \\
\hline
\end{tabular}

County, N.C.

Absent _. - _.

County, N.C.

\begin{tabular}{|c|c|c|c|c|c|c|c|c|}
\hline 3,998 & $518 T$ & 3,023 & $975 T$ & 1,918 & $1,105 T$ & 1,713 & $205 T$ & $\begin{array}{l}\text { Section } J-J^{\prime}, \text { p'ate } 32 \text {; section } \mathrm{Z}^{\prime}{ }^{\prime}-\mathrm{Z}^{\prime} \prime^{\prime} \text {, plate } 51 \text {; } \\
\text { section } C C-C C^{\prime}, \text { plate } 55 \text {. }\end{array}$ \\
\hline \multicolumn{9}{|c|}{ County, N.C. } \\
\hline 6,249 & $140 P$ & 4,904 & $1,345 T$ & 3,859 & $1,045 T$ & 3,337 & $522 T$ & Section $\mathrm{Z}^{\prime}{ }^{\prime} \mathrm{Z}^{\prime}$, , plate 51 . \\
\hline 7,735 & $1,410 T$ & 6,100 & $1,635 T$ & 4,975 & $1,125 T$ & 4,365 & $610 T$ & $\begin{array}{l}\text { Section } G^{\prime}-G^{\prime}, \text { plate } 30 ; \text { section } Z^{\prime}-Z^{\prime}{ }^{\prime} \text {, plate } 50 \text {; } \\
\text { section } Z^{\prime}-Z^{\prime} \text {, plate } 5 \text {. }\end{array}$ \\
\hline 4,676 & $470 T$ & 3,586 & $1,090 T$ & 2,486 & $1,100 T$ & 2,216 & $270 T$ & Section $\mathrm{Z}^{\prime}-\mathrm{Z}^{\prime}{ }^{\prime}$, plate 51 \\
\hline 6,966 & $1,370 T$ & 5,246 & $1,720 T$ & 4,406 & $840 T$ & 3,864 & $542 T$ & Section $\mathrm{Z}^{\prime}{ }^{\prime}-\mathrm{Z}^{\prime}{ }^{\prime}$ ', plate 51. \\
\hline 5,532 & $734 T$ & 4,357 & $1,175 T$ & 3,286 & $1,071 T$ & 2,847 & $439 T$ & Section $F-F^{\prime}$, plate 28 ; section $Z^{\prime}{ }^{\prime}-Z^{\prime}{ }^{\prime}$ ', plate 51 . \\
\hline 4,699 & $420 T$ & 3,644 & $1,055 T$ & 2,547 & $1,097 T$ & 2,279 & $268 T$ & Section $F-F^{\prime}$, plate 28 \\
\hline
\end{tabular}

County, N.C.

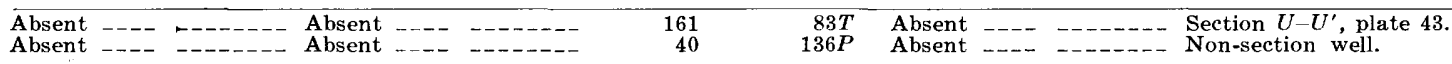

County, N.C.

\begin{tabular}{|c|c|c|c|c|c|c|c|c|}
\hline 4,910 & $650 P$ & 3,920 & $990 T$ & 3,125 & $795 T$ & 2,490 & $635 T$ & Section $G^{\prime}-G^{\prime}$ ', p-ate 30 . \\
\hline 6,116 & $1,120 T$ & 4,954 & $1,162 T$ & 3,996 & $958 T$ & 3,516 & $480 T$ & Section $G^{\prime}-G^{\prime}$, , plate $30 ;$ section $Z^{\prime}-Z^{\prime}$, plate 50 . \\
\hline
\end{tabular}

County, N.C.

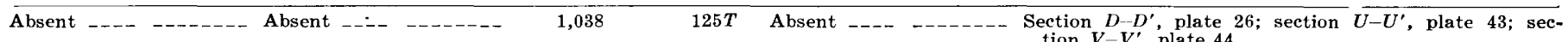
tion $V-V^{\prime}$, plate 44

County, N.C.

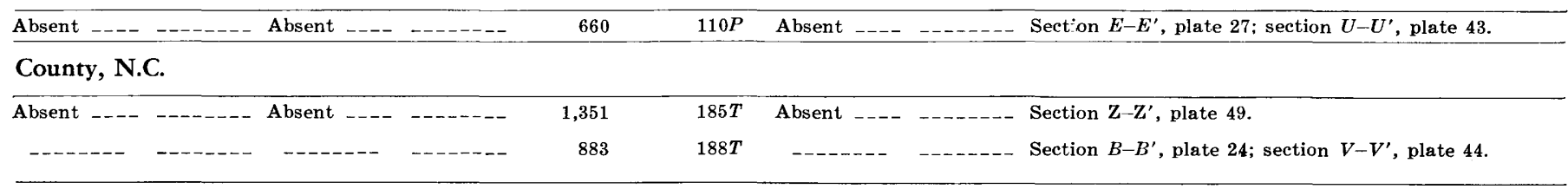


TABLE 2.-Well number, location, date drilled, elevation, depth, and stratigraphic

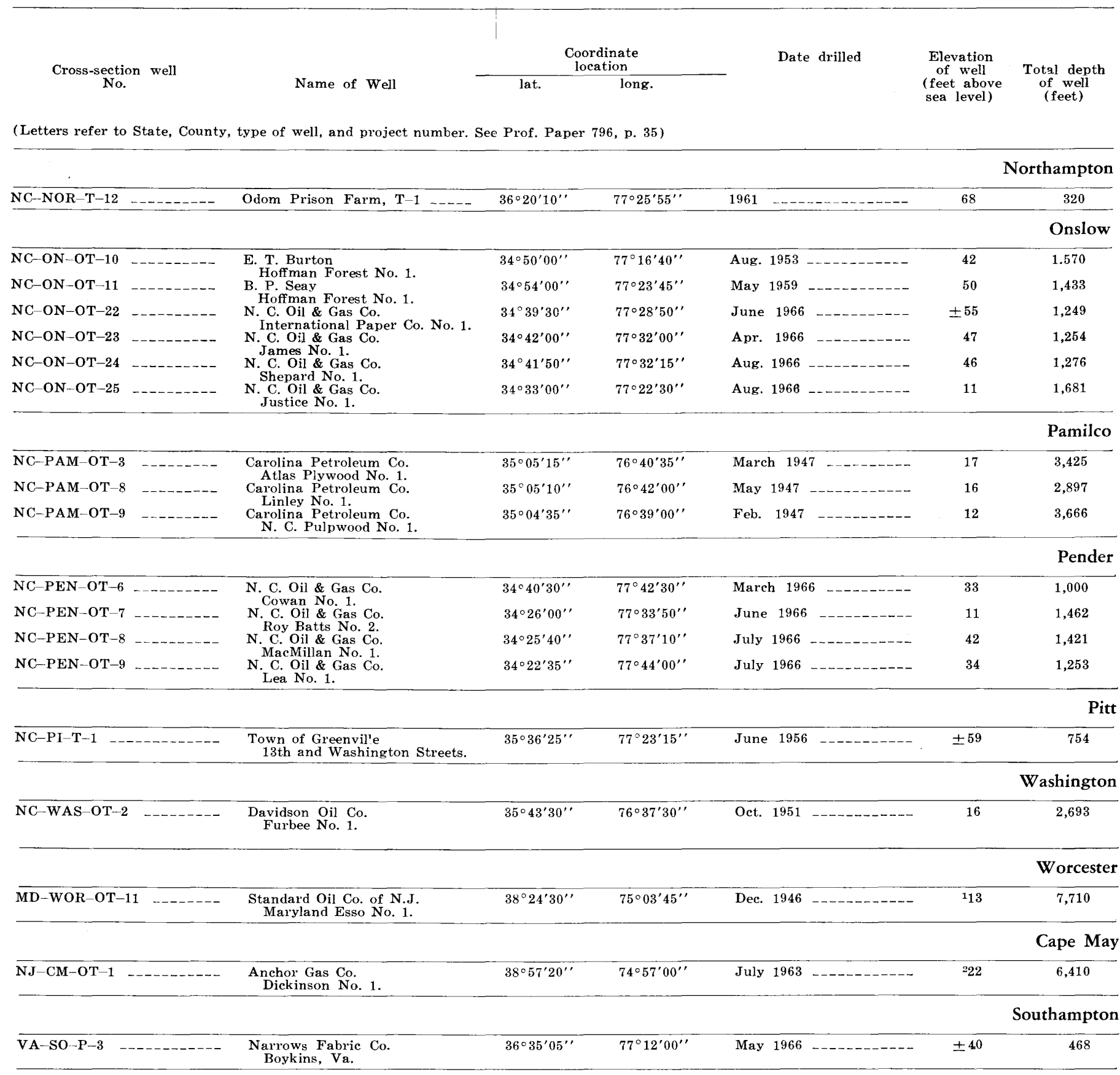

1 Measuring point is 4 feet above L.S.D.

2 Measuring point is 8 feet above L.S.D.

Schuleridea cf. S. acuminata Swartz and Swain, 1946

Schuleridea cf. S. pentagonalis Swartz and Swain, 1946

Gomphocythere ef. G. silvana Martin, 1940

Macrodentina obliqua Swain, 1952

Fabanella tumidosa (Swain, 1952)

Monoceratina sp. Because of the presence of Schuleridea cf. $S .\left.\right|_{\text {level. }} ^{* D}$ acuminata Swartz and Swain (9,075-9,085 $\left.\mathrm{ft}^{*}\right)$ and Schuleridea cf. S. pentagonalis Swartz and Swain (9,090-9,091 $\left.\mathrm{ft}^{*}\right)$ near the base of this unit in a well at Cape Hatteras, N.C. (NC-DA-OT-10, section $Z^{\prime}-Z^{\prime \prime}$, pl. 50), Swain (1952) suggested a

*Depth as given in published report, not converted to feet below sea 
data for the 46 wells from which the Ostracoda were obtained-Continued

\begin{tabular}{|c|c|c|c|c|c|c|c|c|}
\hline \multicolumn{2}{|c|}{ Unit $\mathbf{H}$} & \multicolumn{2}{|c|}{ Unit $G$} & \multicolumn{2}{|c|}{ Unit $\mathbf{F}$} & \multicolumn{2}{|c|}{ Unit $\mathrm{E}$} & \multirow[b]{2}{*}{$\begin{array}{l}\text { Reference cross sections and plates in companion } \\
\text { report by Brown, Miler, and Swain }(1972)\end{array}$} \\
\hline $\begin{array}{l}\text { Depth of } \\
\text { top below } \\
\text { land surface } \\
\text { (feet) }\end{array}$ & $\begin{array}{c}\text { Thickness } \\
\text { (T) or } \\
\text { thickness } \\
\text { penetrated } \\
(P) \\
\text { (feet) }\end{array}$ & $\begin{array}{c}\text { Depth of top } \\
\text { below land } \\
\text { surface } \\
\text { (feet) }\end{array}$ & $\begin{array}{l}\text { Thickness } \\
(T) \text { or } \\
\text { thickness } \\
\text { pentrated } \\
(P) \text { (feet) }\end{array}$ & $\begin{array}{l}\text { Depth of top } \\
\text { below land } \\
\text { surface } \\
\text { (feet) }\end{array}$ & $\begin{array}{l}\text { Thickness } \\
(T) \text { or } \\
\text { thickness } \\
\text { penetrated } \\
(P) \text { (feet) }\end{array}$ & $\begin{array}{l}\text { Depth of top } \\
\text { below land } \\
\text { surface } \\
\text { (feet) }\end{array}$ & $\begin{array}{l}\text { Thickness } \\
(T) \text { or } \\
\text { thickness } \\
\text { penetrated } \\
(P) \text { (feet) }\end{array}$ & \\
\hline
\end{tabular}

County, N.C.

\begin{tabular}{|c|c|c|c|c|c|c|c|c|}
\hline Absent ---- & $--\ldots-\cdots--$ & Absent & -------- & 68 & $144 T$ & Absent .... & $-\cdots------$ & Section $G-G^{\prime}$, plate 29 \\
\hline \multicolumn{9}{|c|}{ County, N.C. } \\
\hline Absent _-_-- & ------- & Absent & ------ & 1,326 & $194 T$ & Absent & ------- & Section $D-D^{\prime}$, plate 26. \\
\hline Absent ---- & -------- & Absent _.-- & -------- & 1,130 & $238 T$ & Absent --.- & ------ & Section $D-D^{\prime}$, plate 26. \\
\hline Absent ---- & $-\cdots-----$ & Absent ---- & -------- & 1,133 & $57 P$ & Absent _-_-- & -------- & Section $C-C^{\prime}$, plate 25 \\
\hline------- & $-\cdots---$ & -------- & ------- & 1,042 & $158 T$ & ------- & -------- & Section $V-V^{\prime}$, plate 44 \\
\hline Absent _---- & -------- & Absent _...- & -------- & 1,112 & $111 T$ & Absent ---- & ------ & Section $C-C^{\prime}$, plate 25 \\
\hline------ & ------- & -------- & ------- & 1,384 & $274 T$ & $-\cdots---\cdots$ & $------\cdots$ & $\begin{array}{l}\text { Section } E-E^{\prime} \text {, plate } 25 \text {; section } U-U^{\prime} \text {, plate } 43 \text {; sec- } \\
\quad \text { tion } \mathrm{Z}-\mathrm{Z}^{\prime} \text {, plate } 49 .\end{array}$ \\
\hline \multicolumn{9}{|c|}{ County, N.C. } \\
\hline Absent _.... & $\ldots-----$ & 2,981 & $424 T$ & 2,353 & $628 T$ & 2,103 & $250 T$ & Section $E-E^{\prime}$, plate 27 ; section $X-X^{\prime}$, plate 46. \\
\hline Absent ---- & ------- & Absent ---- & ------- & 2,238 & $643 P$ & 2,012 & $226 T$ & Non-section well. \\
\hline 3,564 & $84 T$ & 3,083 & $481 T$ & 2,461 & $622 T$ & 2,188 & $273 T$ & $\begin{array}{l}\text { Section } E-E^{\prime} \text {, plate } 27 \text {; section } X-X^{\prime} \text {, plate } 46 \text {; sec- } \\
\quad \text { tion } Y^{\prime}-Y^{\prime} \text {, plate } 48 .\end{array}$ \\
\hline
\end{tabular}

County, N.C.

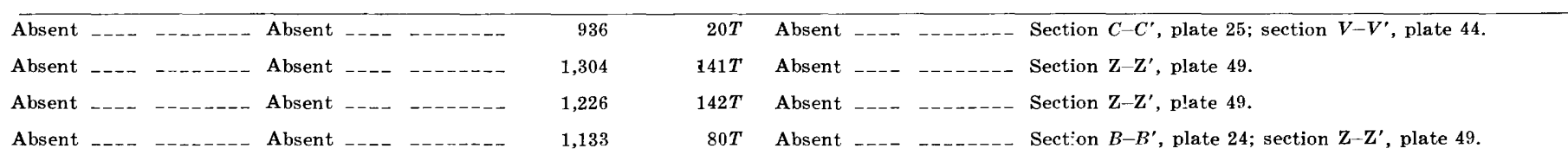

County, N.C.

\begin{tabular}{|c|c|c|c|c|c|c|c|}
\hline Absent --- - ------ & Absent ..... & $-\cdots----$ & 541 & $154 P$ & Absent -..-- & $-\cdots-\cdots$ & Section $U-U^{\prime}$, plate 43 \\
\hline Absent & $2,511 T$ & $162 T$ & 1,558 & $953 T$ & 1,351 & $207 T$ & $\begin{array}{l}\text { Section } F-F^{\prime}, \text { plate } 28 ; \text { section } G-G^{\prime}, \text { plate } 29 \text {; sec- } \\
\text { tion } G^{\prime}-G^{\prime},, \text { plate } 30 ; \text { section } W-W^{\prime}, \text { plate } 45 \text {; } \\
\text { section } Y^{\prime}-Y^{\prime}, \text { plate } 48 .\end{array}$ \\
\hline \multicolumn{8}{|l|}{ County, Md. } \\
\hline $2,072 T$ & 3,937 & $1,162 T$ & 2,725 & $1,212 T$ & 2,499 & $226 T$ & Section $M-M^{\prime}$, plate $35 ;$ section $R-R^{\prime}$, plate 40 \\
\hline $1,776 T$ & 3,544 & $998 T$ & 2,420 & $1,124 T$ & 2,230 & $190 T$ & $\begin{array}{l}\text { Section } O-O^{\prime} \text {, plate } 37 \text {; section } R-R^{\prime} \text {, plate } 40 \text {; sec- } \\
\text { tion } B B^{\prime}-B B^{\prime}, \text {, plate } 54 \text {. }\end{array}$ \\
\hline
\end{tabular}

County, Va.

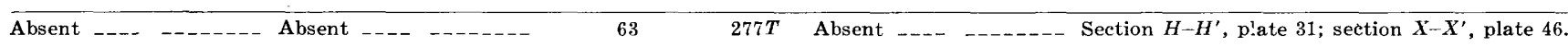

Jurassic (?) age for these beds, which are now included within Unit H. Swain's suggestion of a Jurassic(?) age for the beds containing these species was based on the resemblance of the Schulerideas to similar Ostracoda in the Schuler Formation of Sabinasian Age in the Gulf region. In the present collection described herein, the presence of Otocythere sp. also suggests that beds near the base of Unit $\mathrm{H}$ may be Jurassic (?) in age.

Because the strata of Unit $H$ appear to be correlative in part with the basal Cretaceous Hosston Formation of the Gulf region, which, according to Murray (1961), is mostly of Durango Age, a comparison of Ostracoda from the lower part of the Hosston Formation with the Ostracoda in the collections described herein is of interest. Recently, 
ostracodes from the lower part of the Hosston Formation were collected by E. G. Anderson, Louisiana Department of Conservation, from the Natural Gas No. 1 Napper well, Lincoln Parish, La. Anderson, who is preparing a paper for publication on the Hosston collection, kindly permitted one of the present writers (Swain) to study the Hosston species and to compare them with the species described in this paper. The following comparisons were made:

Dolocytheridea, two or more species of the Hosston Formation resemble D.? bosquetoidea Swain and Brown, n. sp., and D. oertlii Swain and Brown, n. sp., two species that occur in Unit F in North Carolina; however, the North Carolina species are believed to be specifically different from the Hosston Formation forms.

Eocytheropteron sp., unlike the Cretaceous species described in this paper.

Fabanella sp., a unique strongly convex form with flattened anterodorsal slopes, unlike the Cretaceous species from the middle Atlantic States.

Hutsonia sp., a form in which anteromedian lobe is weak or absent and anterior end is bluntly truncated as in H.truncata Swain, 1946, of the Dorcheat Member, Schuler Formation, Upper Jurassic of Louisiana; unlike species of Hutsonia from the middle Atlantic region but resembles Orthonotacythere blanda Kaye, 1963; from the Neocomian of England.

Schuleridea sp. aff. S. acuminata Swartz and Swain, 1946, a species resembling the forms from the lower part of Unit $\mathrm{H}$ in a well drilled at Cape Hatteras, N.C. (NC-DA-OT-10, section $Z^{\prime}-Z^{\prime \prime}$, pl. $50)$.

New genus(?), a subtriangular form something like Mesozoic forms previously assigned to Bairdiocypris; unlike any ostracodes in the collection from the middle Atlantic States.

New genus and species resembling Hutsonia Swain, 1946, or Orthonotacythere Alexander, 1933, somewhat like forms from the underlying Dorcheat Member of the Schuler Formation in the Napper well; unlike any ostracodes from the middle Atlantic States, but resembles Juvenix sp., which occurs in Unit $\mathrm{H}$ in a well in Cape May County, N.J. (NJCM-OT-1, section $O-O^{\prime}$, pl. 37).

With the exception of Schuleridea cf. S. acuminata Swartz and Swain, 1946, it appears that the Ostracoda of the lower part of the Hosston in the No. 1 Napper well bear little resemblance to Ostracoda from Durangoan equivalents in the middle Atlantic States. Both the Hosston Formation of the Gulf region and Unit $\mathrm{H}$ of the Atlantic region may contain beds that are Jurassic to Cretaceous in age.

\section{UNIT G}

In North Carolina the strata of Unit G are chiefly marine or marginal marine and consist predominantly of layers of red, green, and gray shale interbedded with subordinate layers of fine- to mediumgrained micaceous sand. Locally, thin beds of sandy bioclastic limestone or of molluscan limestone may make up as much as 20 percent of the unit. In Virginia and northward into New Jersey, the strata of Unit $G$ are chiefly nonmarine thick layers $(100 \mathrm{ft}$ or more) of massive red and brown shale and thin layers of fine- to medium-grained micaceous sand. Locally, minor amounts of bioclastic limestone or calcareous sand may be present in the section.

The designated type reference section for Unit $G$ is in a well (NC-CAR-OT-5, table 2) located in Carteret County, N.C. The reference section is 942 feet thick (NC-CAR-OT-5, section $Z^{\prime}-Z^{\prime \prime}$, pl. 50) and is the lithologic interval between the depths of 4,092 and 5,034 feet. In the subsurface, Unit G attains a maximum measured thickness of 1,720 feet in a well (NC-DA-OT-12, table 2) in Pamlico Sound, Dare County, N.C. (NC-DA-OT-12, section $Z^{\prime \prime}-Z^{\prime \prime \prime}$, pl. 51).

Unit $\mathrm{G}$ is judged to be correlative with upper and middle Trinity Stage and its typical strata in the Gulf region. Ostracode species recovered from Unit $\mathrm{G}$ are listed in table 1 . New or open species described herein are as follows:

Cytherella sp. 2

*Paracypris sp.

Monoceratina? sp.

Pseudobythocythere? sp.

*Dolocytheridea? bosquetoidea Swain and Brown, n. sp.

*Dolocytheridea oertlii Swain and Brown, n. sp.

* Asciocythere elongata Swain and Brown, n. sp.

Asciocythere? rugosa Swain and Brown, n. sp. Ovocytheridea? sp.

Schuleridea anterofossulata Swain and Brown, n. sp.

* Paraschuleridea twifordensis Swain and Brown, n. sp.

Paraschuleridea postumbonata Swain and Brown, n. sp. Fabanella sp.

*Hutsonia collinsensis collinsensis Swain and Brown, $\mathrm{r}$. sp., n. subsp.

*Hutsonia collinsensis attenuata Swain and Brown, $\mathrm{n}$. subsp.

*Hutsonia collinsensis micropunctata Swain and Brown, n. subsp.

*Hutsonia collinsensis subsp.

*Hutsonia blandoidea Swain and Brown, n. sp.

Protocythere? sp. 2

Klieana? sp.

Cythereis sp.

Isocythereis? sp.

Mandelstamia? sp.

Species marked with an asterisk also occur in one or 
more of the other chronostratigraphic units recognized in the middle Atlantic States. (See table 1.)

The genera Ovocytheridea?, Pseudobythocythere?, and Fabanella have not previously been reported from the United States.

Previously, Swain (1952) identified the following species as occurring in beds now included in Unit $\mathrm{G}$ :

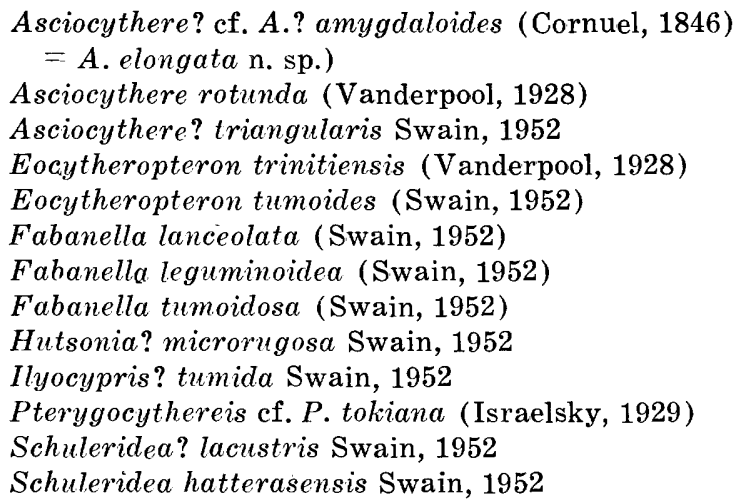

\section{UNIT F}

In North Carolina, the strata of Unit $\mathrm{F}$ are chiefly nonmarine in the inner and central segments of the coastal plain and are marine in its outer segment. In general, the strata are medium to thin bedded predominantly fine- to medium-grained sand interlayered with red and brown shale. Locally, the strata may consist of shell beds or thin beds of bioclastic and molluscan limestone. In Virginia and northward into Long Island, N.Y., the strata of Unit $\mathrm{F}$ are predominantly nonmarine and consist chiefly of coarse- to medium-grained sand interlayered with varicolored shales.

The designated type reference section for Unit $\mathrm{F}$ is in a well (NC-HAL-T-2; section $U-U^{\prime}$, pl. 43) in Halifax County, N.C. The reference section is 83 feet thick and is the lithologic interval between the depths of 161 and 244 feet. In the subsurface Unit $\mathrm{F}$ attains a maximum measured thickness of 1,267 feet in a well (MD-WOR-OT-10, section $M-M^{\prime}$, pl. 35) in Worcester County, $\mathrm{Md}$.

Unit $\mathrm{F}$ is judged to be correlative with the Fredericksburg and Washita Stages and their typical strata in the Gulf region. A marine and a brackish-water assemblage of Ostracoda is recognized in Unit F. Ostracode species recovered from Unit $\mathrm{F}$ are listed in table 1 . New and open taxa described herein are as follows:

\footnotetext{
*Dolocytheridea? bosquetoidea Swain and Brown, n. sp.

*Dolocytheridea oertlii Swain and Brown, n. sp.

*Asciocythere elongata Swain and Brown, n. sp.

* Metacytheropteron? bicostatum Swain and Brown, n. sp.
}

Eucytherura sp.

Protocythere? sp. 1

Species marked with an asterisk also occur in one or more of the other chronostratigraphic units recognized in the middle Atlantic States. (See table 1.)

Previously, Swain (in Anderson and others, 1948; 1952) or Swain and Brown (1964) identified the following species as occurring in beds now included in Unit $\mathrm{F}$ :

\begin{abstract}
Cythereis simulonuda Swain, 1952
Eocytheropteron acaudatum (Swain, 1952)

Clithrocytheridea halifaxensis Swain and Brown, 1964

Cythereis pittensis Swain and Brown, 1964

Cythereis sp. aff. C. glabrella Triebel, 1940

Dolocytheridea? caledonensis Swain and Brown, 1964

Eocytheropteron greenvillensis Swain and Brown, 1964

Eocytheropteron venoides Swain and Brown, 1964

Eucythere semiglypta Swain and Brown, 1964

Eucythere pustulosa (Swain, 1948, in Anderson and others)

Fossocytheridea lenoirensis Swain and Brown, 1964

Haplocytheridea multiclefta Swain and Brown, 1964

Orthonotacythere delicatula Swain and Brown, 1964

Perissocytheridea odomensis Swain and Brown, 1964
\end{abstract}

\section{UNIT .E}

The strata of Unit $\mathrm{E}$ are marine to nonmarine in most of North Carolina and in southeast Virginia; nonmarine in Delaware and Maryland; marine to marginal marine in New Jersey; and nonmarine on Long Island, N.Y. In North Carolina and southeast Virginia the marine strata consist predominantly of gray shale interlayered with sandy molluscan limestone, whereas the nonmarine strata consist predominantly of red micaceous shales interlayered with coarse-grained sands. From southeast Virginia and northward to Long Island, N.Y., the strata consists predominantly of green, gray, and brown lignitic shales and minor amounts of fine-grained sands. Locally, as in the coastal area of New Jersey, the strata also may consist of limestone or thin shell beds interlayered with sand and shale.

The designated type reference section for Unit $\mathrm{E}$ is in a well (NC-DA-OT-11, table 2) located in Albemarle Sound, Dare County, N.C. The reference section is 270 feet thick (NC-DA-OT-11, section $\left.Z^{\prime \prime}-Z^{\prime \prime \prime}, \mathrm{pl} .51\right)$ and is the lithologic interval between the depths of 2,216 and 2,486 feet. In the subsurface Unit $\mathrm{E}$ attains a maximum measured thickness of 635 feet in a well (NC-HY-OT-6, table 2) southeast of Lake Mattamuskeet, Hyde County, N.C. (NC-HY-OT-6, section $G^{\prime}-G^{\prime \prime}$, pl. $30)$. 
Unit $\mathrm{E}$ is judged to be correlative with the Woodbine Stage and its typical strata in the Gulf region. Ostracode species recovered from Unit $\mathbf{E}$ are listed in table 1 . New and open taxa described herein are as follows:

Cytherella sp. 1

*Dolocytheridea? bosquetoidea Swain and Brown, n. sp.

*Dolocytheridea oertlii Swain and Brown, n. sp.

Schuleridea? sp.

Species marked with an asterisk also occur in one or more of the other chronostratigraphic units recognized in the middle Atlantic States. (See table 1.)

Previously, Swain (1952) and Swain and Brown (1964) identified the following species as occurring in beds now included in Unit $\mathbf{E}$ :

Bairdia cf. B. alexandrina Blake, 1931

Cythereis ef. C. bicornis Israelsky, 1929

Cythereis eaglefordensis Alexander, 1929

Cythereis fredricksburgoides Swain and Brown, 1964

Cythereis ornatissima (Reuss, 1846)

Cythereis sp. aff. C. rugosissima Alexander, 1929

Cythereis simulonuda Swain, 1952

Cytheropteron (Cytheropteron) eximium Alexander, 1933

Haplocytheridea? graysonensis (Alexander, 1929)

Pterygocythereis cf. P. tokiana (Israelsky, 1929)

\section{SYSTEMATIC DESCRIPTIONS}

\section{Subclass OSTRACODA Latreille, 1806 Order PODOCOPIDA Müller, 1894}

Suborder PLATYCOPINA Sars, 1866

Family CYTHERELLIDAE Sars, 1866

\section{Genus CYTHERELLA Jones, 1849}

Cytherella Jones, 1849, Mon. Cretaceous Entomostraca, Palaeontographical Soc., p. 28.

Shell medium sized, elliptical to ovate; dorsum and venter vary from straight and subparallel to gently convex; ends rounded; right valve larger than left; surface smooth, pitted, or ribbed. Hinge of right valve a furrow to receive ridge in edge of left valve; adductor muscle scar two opposing curved rows of several spots; inner lamellae? and radial canals lacking.

Type species.-Cytherina ovata Roemer, 1840.

Geologic range.-Triassic to Holocene.

\section{Cytherella cf. C. ovata (Roemer)}

Plate 1, figure 16

Cytherina ovata Roemer, 1840, Die Versteinerungen des norddeutschen Kreidegebirges, Hannover, p. 104, pl. 16, fig. 21.
Cytherella ovata (Roemer). Jones, 1849, Mon. Cretaceous Entomostraca, Palaeontographical Soc., p. 28, pl. 7, figs. 24a-g (not 24i, fide Howe and Laurencich (1958)).

Jones and Hinde, 1890, Suppl. Mon. Cretaceous Entomostraca, Palaeontographical Soc. p. 44, pl. 2, figs. 48-54.

Bonnema, 1940, Natuurh. Maandblad, v. 27, p. 93, pl. 1, figs. 1-16.

?Deroo, 1956, Rev. Inst. française Petrole et Annales Combust. Liquides, v. 11, p. 1508, 1523, pl. 1, figs. 4-6.

Brown, 1957, North Carolina Dept. Conserv. and Devel. Bull. 70, p. 7 .

Outline ovate-elliptical; dorsum slightly convex; ends nearly equally rounded; surface with median, slightly dorsal pit, otherwise smooth; right valve overlaps and extends beyond left strongly along dorsum and venter.

Length of figured specimen $0.82 \mathrm{~mm}$, height 0.50 $\mathrm{mm}$, width $0.33 \mathrm{~mm}$.

Occurrence.-

Unit F :

NJ-CM-OT-1, 3,418-3,428 feet (section $O-O^{\prime}$, pl. 37).

Number of specimens studied.-25+.

Figured specimen.-USNM 177609.

\section{Cytherella sp. 1 \\ Plate 1, figure 17}

Shell elongate-subovate, highest part is one-fifth of shell length from anterior end; dorsum nearly straight and four-fifths of shell length; venter convex, converging posteriorly toward dorsum; anterior margin broadly curved, extended medially; posterior margin narrowly rounded, extended above; valve surface with small dorsomedian pits; most of surface densely and finely pitted. Internal features not observed.

Length of figured specimen $0.65 \mathrm{~mm}$, height 0.32 $\mathrm{mm}$, width not determined because matrix obscures end of shell.

Relationships.-The species is similar to $C$. foveata Veen, 1932, in having a fairly elongate shape and medium dorsal pit, but it has a straighter dorsum than that species and is pitted rather than longitudinally striated.

Occurrence.-

Unit E :

NC-CAR-OT-7, 3,080-3,090 feet (section $D-D^{\prime}$, pl. 26)

Number of specimens studied.-Two.

Figured specimen.-USNM 177608.

\section{Cytherella sp. 2}

Plate 1, figure 12

The illustrated ovate specimen was obtained from 
Unit G, NC-DA-OT-12, 6,096-6,106 feet (section $Z^{\prime \prime}-Z^{\prime \prime \prime}$, pl. 51).

Number of specimens studied.-Four.

Figured specimen.-USNM 177610.

\section{Suborder PODOCOPINA Sars, 1866 Superfamily CYPRIDACEA Baird, 1845 Family ILYOCYPRIDIDAE Kaufmann, 1900 Subfamily CYPRIDEINAE Martin, 1940}

\section{Genus CYPRIDEA Bosquet, 1852}

Cypridea Bosquet, 1852, Acad. royale Belgique Mém. cour. et sav. étrang., v. 24, p. 47.

\section{Subgenus CYPRIDEA Bosquet, 1852}

Shell subquadrate, medium sized; dorsum nearly straight; cardinal angles obtuse; anterior broadly curved with anteroventral projecting "beak"; posterior narrower; surface smooth, pitted, nodose, and (or) weakly sulcate. Hinge of left valve a groove with socketlike terminations, commonly crenulate. Nonmarine.

Type species.-Cypris granulosa Sowerby, 1836. Geologic range.-Triassic to Eocene.

\section{Cypridea (C.) dequeenensis Swain and Brown}

Plate 1, figure 18; text figure 2

Cypridea ventrosa var. bispinosus Vanderpool, 1928, Jour. .Paleontology, v. 2, p. 104, pl. 14, figs. 1, 2.

?Cypridea cf. ventrosa bispinosus (Jones). Calahan, 1939, Shreveport Geol. Soc. Guidebook, 14th Ann. Field Trip, p. 55, pl. 8, figs. 9 a, b.

Cypridea dequeenensis Swain and Brown, 1964, North Carolina Dept. Conserv. and Devel., Bull. 78, p. 15-16, pl. 4, fig. 8; pl. 5, figs. 3a-c; text figs. 3c-4a.

not Cypridea bispinosa Jones, 1878, Geol. Mag. Dec. 2, v. 5, p. 109, pl. 3, figs. $9,10$.

not Cypridea bispinosa Galeeva, 1955, Cretaceous ostracod succession of Mongolian Peoples Republic, p. 36, figs. 1a-g.

Liubimova, 1956 All-Union Petroleum Scientific Research Geol. Exploration Inst. (VNIGRI), Trans. n.s., no. 93, p. 25, pl. 5, fig. 2a, b, 3a, b, 4; (fide) Howe and Laurencich, 1958, p. 119.

Cypridea kleinbergi Galeeva, 1955, Cretaceous ostracod succession of Mongolian Peoples Republic, p. 31, pl. 8, figs. 2a-e $(=C$. bispinosa Galeeva by Howe and Laurencich, 1958).

\section{Occurrence.-}

\section{Unit $\mathrm{H}$ :}

NC-DA-OT-12, 7,306-7,316 feet (section $Z^{\prime \prime}-Z^{\prime \prime \prime}$, pl. 51)

The species was described from the De Queen Limestone, Trinity Group of Arkansas.

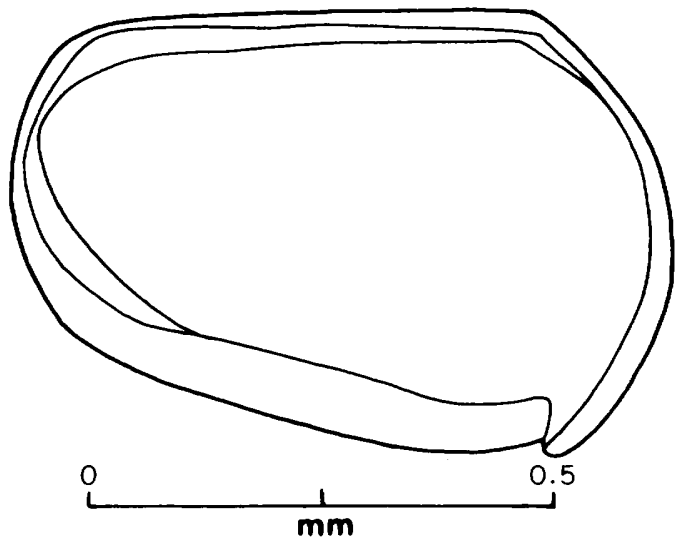

Figure 2.-Cypridea (C.) dequeenensis Swain and Brown. Interior view of left valve. Unit H. NC-DA-OT-12 well, 7,306-7,316 feet, USNM 177613.

Number of specimens studied.-Two.

F'igured specimen.-USNM 177613.

\section{Cypridea (C.) diminuta Vanderpool}

Cypridea diminutus Vanderpool, 1928, Jour. Paleontology, v. 2, p. 103, pl. 13, figs. 7, 8 .

Cypridea diminuta Vanderpool. Peck, 1941, Jour. Paleonto$\operatorname{logy}$, v. 15 , p. 298 , pl. 44 , fig. 32 (not figs. $29-31=$ C. pecki Sohn, 1969).

Peck, 1951, Jour. Paleontology, v. 25, p. 312, pl. 49, fig 6.

Howe and Laurencich, 1958, Introd. study Cretaceous Ostracoda, p. 121.

Swain and Brown, 1964, North Carolina Dept. Conserv. and Devel. Bull. 78, p. 16, pl. 4, fig. 9; pl. 5, figs. 2a$\mathrm{d}$; text fig. $3 b$.

\section{Occurrence.-}

Unit $\mathrm{G}$ :

NC-DA-OT-12, 5,596-5,606 feet (section $Z^{\prime \prime}-Z^{\prime \prime \prime}$, pl. 51)

Number of specimens studied.-One.

\section{Cypridea (C.) menevoides Swain and Brown, n, sp.}

Plate 1, figure 21

Diagnosis. - Subquadrate to subtrapezoidal, medium-sized Cypridea having right valve larger than left, finely pitted surface medially and smooth marginal zones.

Description.-Shell medium sized, subquadrate to subtrapezoidal in side view; highest one-fifth from anterior end; dorsal margin nearly straight; cardinal angles broadly obtuse; ventral margin slightly convex, sinuous terminally, converging toward dor- 
sum posteriorly; anterior margin broadly curved, truncate above, anteroventral marginal bend extended as a blunt beak, and marked posteriorly by a notch; posterior margin narrower; right valve much larger than left, overlapping and extending beyond right along free margins; along dorsum left valve overlaps right; valves not strongly convex; surface finely pitted except marginal zone which is smooth; anteroventral furrow and hood well developed.

Inner lamellae relatively narrow, as seen by transmitted light, no radial canals observed; hingement is represented by rabbet grooves in each valve, with small notches at either end of hinge of left valve into which fit small projections of right valve; adductor muscle scar could not be seen.

Length of holotype $0.98 \mathrm{~mm}$, height $0.62 \mathrm{~mm}$, width $0.42 \mathrm{~mm}$. Type locality NC-CUR-OT-12 well, Currituck County, N.C.; type horizon Unit H, 4,308-4,318 feet.

Relationships.-In the overlap of the left valve by the right, general shape and surface pitting, this species is similar to C. ("Ulwellia") (Anderson, 1939) from the Wealden beds of England. The new species has a broader anteroventral "hood" and somewhat longer adjacent notch.

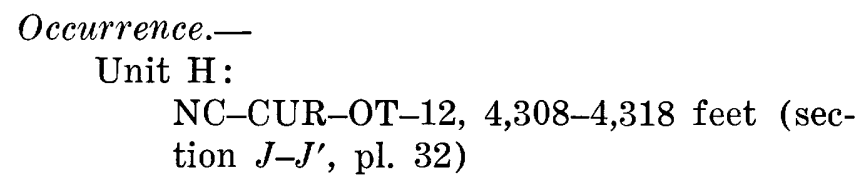

Number of specimens studied.-Five.

Figured specimen.-USNM 177617 (holotype).

\section{Cypridea (C.) wyomingensis Jones}

Plate 1, figures 19-20; plate 3, figure 1

Cypridea tuberculata wyomingensis Jones, 1893, Geol. Mag., Dec. 3, v. 10 , p. 386 , pl. 15, figs. 5a, b, 6a, b.

White, 1895, U.S. Geol. Survey Bull. 128, p. 62, pl. 11, figs. $5 \mathrm{a}, \mathrm{b}, 6 \mathrm{a}, \mathrm{b}$.

Cypridea tuberculata gypsumensis Vanderpool, 1928, Jour. Paleontology, v. 2, p. 103, pl. 13, figs. 9-12.

Cypridea wyomingensis (Jones). Peck, 1941, Jour. Paleonto$\operatorname{logy}$, v. 15, p. 297 , pl. 43 , figs. 10-17.

Peck, 1951, Jour. Paleontology, v. 25, p. 312, pl. 48, figs. 4-7.

Loranger, 1951, Am. Assoc. Petroleum Geologists Bull., v. 35 , p. 2363 , pl. 2 , fig. 2.

Loranger, 1954, in Western Canada Sedimentary Basin, Am. Assoc. Petroleum Geologists, p. 293, pl. 2, fig. 22 .

Howe and Laurencich, 1958, Introd. study Cretaceous Ostracoda, p. 142.

Swain and Brown, 1964, North Carolina Dept. Conserv. and Devel. Bull. 78, p. 16, pl. 4, fig. 10, pl. 5, figs. 1a-c; text fig. $4 \mathrm{~b}$.
Cypridea cf. C. wyomingensis (Jones). Swartz and Swain, 1946, Jour. Paleontology, v. 20, p. 372, pl. 52, figs. 1922.

Shell subquadrate-trapezoidal; dorsum and venter nearly straight, converging posteriorly; cardinal angles broadly obtuse; anterior broadly curved; posterior much narrower; left valve extends beyond right along free margins; surface densely and finely pitted; dorsal and ventral third of each valve surface with about 15 coarse pustules; anteroventral marginal notch and beak vary from weak to prominent.

Hinge consists of rabbet grooves and terminal small triangular elevations in right, and depressions in left, valve; inner lamellae narrow, radial canals apparently are absent; adductor muscle scar a slightly anteromedian group of four or five spots.

Length of figured specimen (USNM 177612, pl. 1, fig. 20) $0.90 \mathrm{~mm}$, height $0.53 \mathrm{~mm}$, width $0.24 \mathrm{~mm}$.

Remarks.-The outline of the shell and the surface pattern of spines and pits of the present specimens seem identical to features of $C$. wyomingensis.

Occurrence.-

Unit $\mathrm{H}$ :

NC-DA-OT-9, 6,379-6,389 feet (section $Z^{\prime \prime}-Z^{\prime \prime \prime}$, pl. 51)

Unit $\mathrm{G}$ :

NC-DA-OT-11, 4,446-4,456 feet and 4,596-4,606 feet (section $Z^{\prime \prime}-Z^{\prime \prime \prime}$, pl. 51)

NC-HY-OT-11, 5,016-5,026 feet (section $G^{\prime}-G^{\prime \prime}$, pl. 30)

NC-CAR-OT-5, 4,722-4,732 feet (section $E-E^{\prime}$, pl. 27)

NC-CAR-OT-7, 4,440-4,450 feet (section $D-D^{\prime}$, pl. 26)

NC-DA-OT-13, 4,707-4,717 feet (section $F^{\prime}-F^{\prime}$, pl. 28)

NC-DA-OT-14, 4,139-4,149 feet (section $F-F^{\prime}$, pl. 28)

NC-CUR-OT-12, 3,868-3,878 feet (section $Z^{\prime \prime}-Z^{\prime \prime \prime}$, pl. 51)

Elsewhere the species occurs in the Lower Cretaceous Bear River Formation of Wyoming, and De Queen Limestone of Arkansas, and questionably in the Upper Jurassic Schuler Formation of Arkansas.

Number of specimens studied.-12.

Figured specimens.-USNM 177611, 177612.

\section{Cypridea (C.) sp.}

Plate 1, figures 22-25

Shell subquadrate-subtrapezoidal in side view; highest one-third from anterior end; dorsal margin 
moderately convex, truncated before and behind position of greatest height; ventral margin nearly straight; anterior margin broadly curved, angulated at anteroventral marginal bend; posterior margin narrowly curved, strongly extended below, sharply angulated at ventral marginal bend; surface of valves densely and finely pitted; anteroventral beak short, not much extended beyond margin.

Inner lamellae of moderate width, broadest anteriorly, narrow vestibule anteriorly; a few short radial canals visible along anterior; hingement consists or rabbet grooves along margin of each valve; muscle scar a median compact group of five spots.

Length of a shell that is imperfect posteriorly, and also appears somewhat compressed perpendicular to plane separating valves (USNM 177616, pl. 1, fig. 24) $0.53 \mathrm{~mm}$, height $0.42 \mathrm{~mm}$, width $0.18 \mathrm{~mm}$.

Remarks.-In general form, compressed valves, and angulated anteroventral margin, this species resembles Cypridea modica Liubimova, 1955. That species is shorter and higher than, and does not have the dense surface pitting of, the present form.

Occurrence.-

Unit $\mathrm{H}$ :

NC-DA-OT-12, 7,146-7,156 feet (section $Z^{\prime \prime}-Z^{\prime \prime \prime}$, pl. 51)

Number of specimens studied.-Four.

Figured specimens.-USNM 177614, 177615, 177616.

Family CYPRIDIDAE Baird, 1845 Subfamily CYPRIDOPSINAE Kaufmann, 1900'

\section{Genus POTAMOCYPRIS Brady, 1870}

Potamocypris Brady, 1870, Trans. Nat. History Soc. Northumberland, v. 3 , p. 365.

Shell subreniform-subtriangular; dorsum strongly arched, subumbonate; venter concave; anterior margin less narrowly rounded than posterior, both are strongly extended below; left valve markedly larger than right, extending strongly beyond right along dorsum and perhaps along venter; surface pitted. Hinge adont, inner lamellae moderately broad terminally; adductor muscle scar a median group of as much as seven spots and two additional moreanterior spots. Fresh water.

Type species.-Bairdia fulva Brady, 1868.

Geologic range.-Lower Cretaceous(?), Upper Cretaceous to Holocene.

\section{Potamocypris? sp.}

Plate 1, figure 15

Shell elongate, subtriangular to subreniform; dorsum strongly convex; venter slightly concave; anterior margin narrowly rounded; posterior margin subacuminate; left valve larger than right, overreaching it strongly dorsally and less strongly ventrally; surface apparently smooth but poorly preserved. Internal structures not seen.

\section{Occurrence.-}

Unit $\mathrm{H}$ :

NC-DA-OT-12, 7,836-7,846 feet (section $Z^{\prime \prime}-Z^{\prime \prime \prime}$, pl. 51)

Number of specimens studied.-One.

Figured specimen.-USNM 177618.

\section{Family PARACYPRIDIDAE Sars, 1923}

\section{Genus PARACYPRIS Sars, 1866}

Paracypris Sars, 1866, Norske Vidensk.-Akad. Forh., Oversigt af Norges Marine Ostracoder, p. 12.

Shell small, elongate sublanceolate-subreniform; dorsum convex; venter concave; anterior rounded; posterior acuminate, strongly extended below; valves compressed, left valve larger than right; surface smooth. Hinge consists of simple contact of right valve in slight furrow on left valve; inner lamellae broad; radial canals may bifurcate; adductor muscle scar a median group of six or more spots.

Type species.-Paracypris polita Sars, 1866.

Geologic range.—Silurian(?), Triassic(?), Jurassic to Holocene.

\section{Paracypris goodlandensis Howe and Laurencich}

Paracypris siliqua Jones and Hinde. Alexander, 1929, Univ. Texas Bull. 2907, p. 64, pl. 3, figs. 11, 13.

Paracypris goodlandensis Howe and Laurencich, 1958, Introd. study Cretaceous Ostracoda, p. 448, text fig.

Swain and Brown, 1964, North Carolina Dept. Conserv. and Devel. Bull. 78, p. 13, pl. 1, figs. $7 a-c$.

The species has been recorded from the Goodland (upper part), Kiamichi, and Grayson Formations of Texas, Washita and Fredericksburg Stages, and from the lower member of the Atkinson Formation, subsurface of Georgia.

Occurrence.-

Unit F :

NC-NH-OT-15, 1,471-1,481 feet (section $Z-Z^{\prime}$, pl. 49)

NC-CAR-OT-10, 2,633-2,643 feet (Nonsection well)

Number of specimens studied.-25+.

\section{Paracypris sp.}

Plate 1, figures 13, 14

Paracypris sp. $\quad$ Swain, 1952, U.S. Geol. Survey Prof. Paper 234-B, p. 70, pl. 8, fig. 7 . 


\section{Occurrence.-}

Unit $\mathrm{H}$ :

NC-DA-OT-12, 7,146-7,166 feet (sec-

tion $Z^{\prime \prime}-Z^{\prime \prime \prime}$, pl. 51)

Unit $\mathrm{G}$ :

NC-DA-OT-10, 6,675-6,685 feet* (section $G^{\prime}-G^{\prime \prime}$, pl. 30)

NC-DA-OT-12, 6,696-6,706 feet (section $Z^{\prime \prime}-Z^{\prime \prime \prime}$, pl. 51)

Number of specimens studied.-Three.

Figured specimens.-USNM 177619, 177620.

\section{Superfamily DARWINULACEA Brady and Norman, 1889 \\ Family DARWINULIDAE Brady and Norman, 1889}

\section{Genus DARWINULA Brady and Robertson, 1885}

Polycheles Brady and Robertson, 1870, Annals and Mag. Nat. History, ser. 4, v. 6, p. 25 (not Heller, 1862).

Darwinella Brady and Robertson, 1872, Annals and Mag. Nat. History, ser. 4, v. 9, p. 50 (not Müller, 1865).

Darwinula Brady and Norman, 1889, Trans. Royal Dublin Soc., ser. 2, v. 4, p. 121.

Shell elongate subelliptical, sublanceolate or suboblong; highest posteriorly; dorsal and ventral margins gently convex, converging anteriorly; terminal margins rounded, the anterior narrower; right valve in type species larger than left, overlapping it; in other species left valve is larger than right; valves moderately to strongly convex; surface smooth. Hingement provided by simple right valve overlap; adductor muscle scar an anteromedian circular group of radially arranged spots; inner lamellae absent or weakly developed. Fresh water or brackish water.

Type species.-Polycheles stevensoni Brady and Robertson, 1870.

Geologic range.-Ordovician, Upper Carboniferous to Holocene.

\section{Darwinula rogersii (Jones)}

Plate 1, figures 6, 7; text figure 3

Candona? rogersii Jones, 1862, Mon. fossil Estheridae, p. 124, pl. 5, figs. 20-22.

Shell subelliptical to sublanceolate in side view, highest medially to posteromedially; dorsal margin gently convex, passing more abruptly into posterior than into anterior margin; ventral margin slightly convex; anterior margin narrowly rounded, extended below; posterior margin broadly curved, extended medially; valves slightly convex; surface
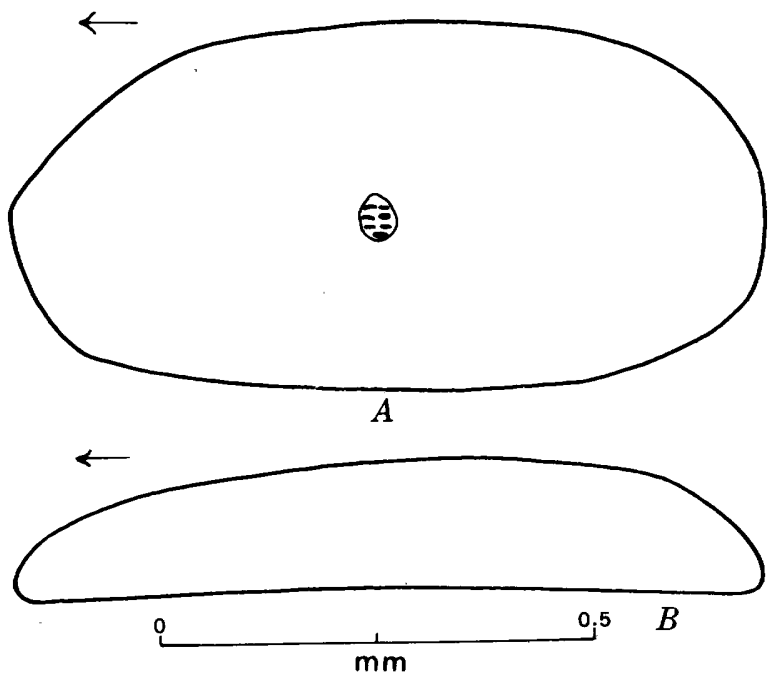

Figure 3.-Darwinula rogersii (Jones). A, Exterior view of left valve; $B$, ventral view of left valve. Cumnock Formation, Upper Triassic, Bethany Church, near Gulf, N.C. USNM 177727.

smooth. Adductor muscle scar an anteromedian rounded spot; other internal structures not seen.

Length of figured specimen (USNM 177727, pl. 1, fig. 7) $0.85 \mathrm{~mm}$, height $0.39 \mathrm{~mm}$, width of valve $0.15 \mathrm{~mm}$.

Relationships.-This species differs from $D$. subquadrata $\mathrm{n}$. sp. in having on the left valve a curved dorsum rather than a straightened middorsal margin and truncate dorsal slopes as in subquadrata. The ornamentation of the interior of the species was not seen in the present form.

Occurrence.-Rare in Cumnock Formation, Upper Triassic, Bethany Church locality 0.5 mile west of Gulf, Chatham County, N.C.; originally described from Triassic (Keuper) shales near Richmond, Va. and Deep River, N.C.

Number of specimens studied.-Four.

Figured specimens.-USNM 177726, 177727.

\section{Darwinula subquadrata Swain and Brown, n. sp.}

Plate 1, figures 1-5; plate 2, figures 2,3 ; text figure 4

Diagnosis.-Subquadrate Darwinula with subparallel dorsum and venter; interior valve surface delicately reticulate; $l / h=0.25$.

Description.-Shell subelliptical to subquadrate in side view, highest medially; dorsal margin straight, about half of shell length, with broadly obtuse cardinal marginal angles; ventral margin nearly straight, subparallel to dorsum; anterior margin 

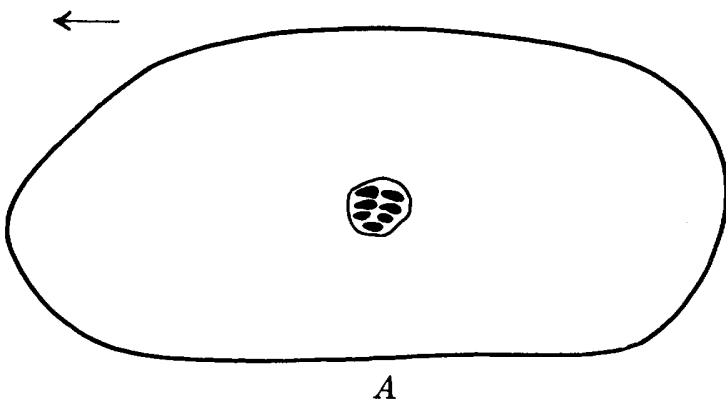

i
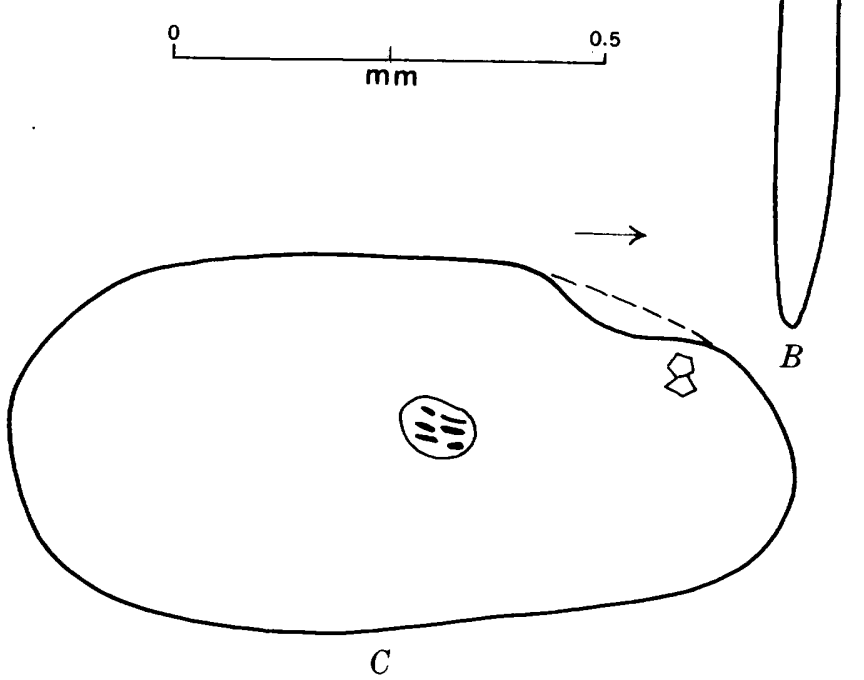

FIGURE 4.-Darwinula subquadrata Swain and Brown, $\mathrm{n}$. sp. A, Exterior view of holotype (USNM 177721) left valve; $B$, ventral view of holotype left valve; $C$, exterior of paratype right valve. Cumnock Formation, Upper Triassic, Bethany Church, near Gulf, N.C. USNM 177721, 177722.

narrowly curved, truncate above; posterior margin somewhat more broadly rounded, also subtruncate above; valves slightly convex, greatest convexity median. Muscle scar an anteromedian circular spot with longitudinal internal markings. Exterior surface of valve smooth; interior surface delicately reticulate.

Length of holotype left valve (USNM 177721, pl. 1, fig. 1) $0.83 \mathrm{~mm}$, height $0.33 \mathrm{~mm}$, convexity of valve $0.13 \mathrm{~mm}$. Type locality Bethany Church, 0.5 mile west of Gulf, Chatham County, N.C.; type horizon Cumnock Formation, Upper Triassic.

Relationships.-This species is distinguished from others of the present collection by its straight, subparallel dorsal and ventral margins and truncate dorsal slopes, together with its weakly convex shell. Compared with D.? emmonsii (Jones, 1862), the present form is more quadrate, has a straighter dorsum, and has internal rather than external ornamentation.
Occurrence.-Very abundant in Cumnock Formation, Upper Triassic, 0.5 mile west of Gulf, Chatham County, N.C. Also abundant in Upper Triassic shales near Carpenter, Wake County, N.C.

Number of specimens studied.- $100+$.

Figured specimens.-USNM 177717, 177718, 177721 (holotype), 177722 (paratype), 177723 (paratype), 177724 (paratype), 177725 (paratype).

\section{Darwinula? sp. 1}

Plate 1, figure 8; plate 2, figure 5; text figure 5

Shell elongate-sublanceolate, highest posteromedially; dorsal margin gently convex; ventral margin slightly sinuous, nearly straight; anterior margin narrowly rounded, extended medially; posterior margin more broadly rounded; valve surface moderately convex; surface smooth. Internal structures not seen.

Length of left valve (USNM 177728, pl. 1, fig. 8) $0.90 \mathrm{~mm}$, height $0.32 \mathrm{~mm}$, width $0.13 \mathrm{~mm}$.

Relationships.-This species is more elongate than is typical of the genus, but conforms in outline and convexity to Darwinula. The sinuous venter may be due in part to distortion of the valve. The rareness of the form and lack of information about internal shell details prevents definite generic assignment.

Occurrence.-Rare in Cumnock Formation, Upper Triassic, Bethany Church locality, 0.5 mile west of Gulf, Chatham County, N.C. Occurs also in un-

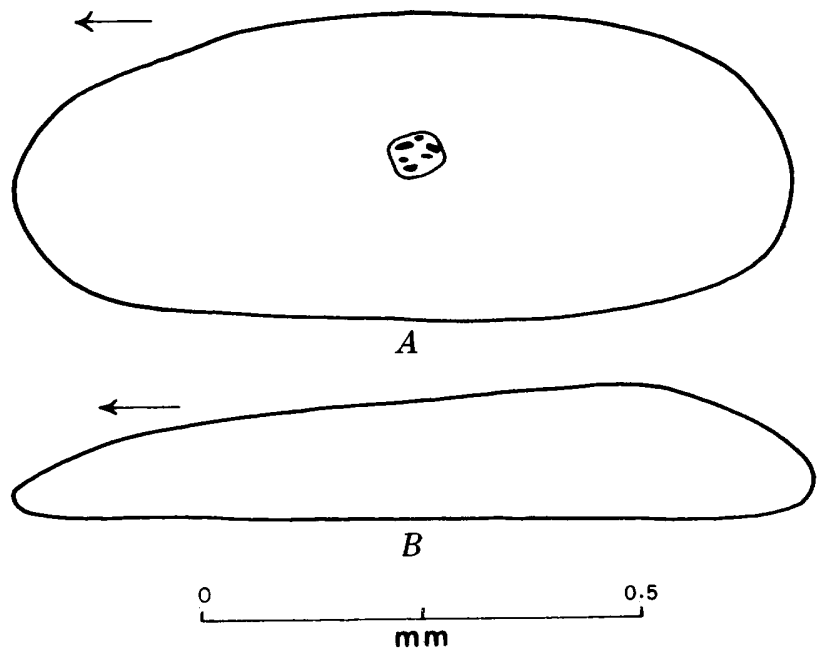

Figure 5.-Darwinula? sp. 1. A, Exterior view of left valve; $B$, ventral view of left valve. Cumnock Formation, Upper Triassic, Bethany Church, near Gulf, N.C. USNM 177720, 177728. 
differentiated sediments of Late Triassic age near Carpenter, Wake County, N.C.

Number of specimens studied.-Four.

Figured specimens._USNM 177728, 1177720.

Darwinula? sp. 2

Plate 1, figure 9 ; plate 2 , figures 1,4 ; text figure 6

Shell elongate-subelliptical in lateral view, highest submedially; dorsal and ventral margins gently convex, converging toward anterior; anterior margin rounded, sightly extended below; posterior margin broader but sharply curved and extended medially; valve surface moderately convex; surface smooth. Internal shell structure not seen.

Length of figured right valve specimen $0.93 \mathrm{~mm}$, height $0.40 \mathrm{~mm}$, width $0.17 \mathrm{~mm}$.

Relationships.-The relatively greater height with respect to length and the angulated posterior margin distinguish this species from other Darwinula? in the collection.

Occurrence.-Rare in Cumnock Formation, Upper Triassic, Bethany Church locality, 0.5 mile west of Gulf, Chatham County, N.C. Occurs also in undifferentiated sedimentary rocks of Late Triassic age near Carpenter, Wake County, N.C.

Number of specimens studied.-Three.

Figured specimens.-USNM 177716, 177719, 177729.
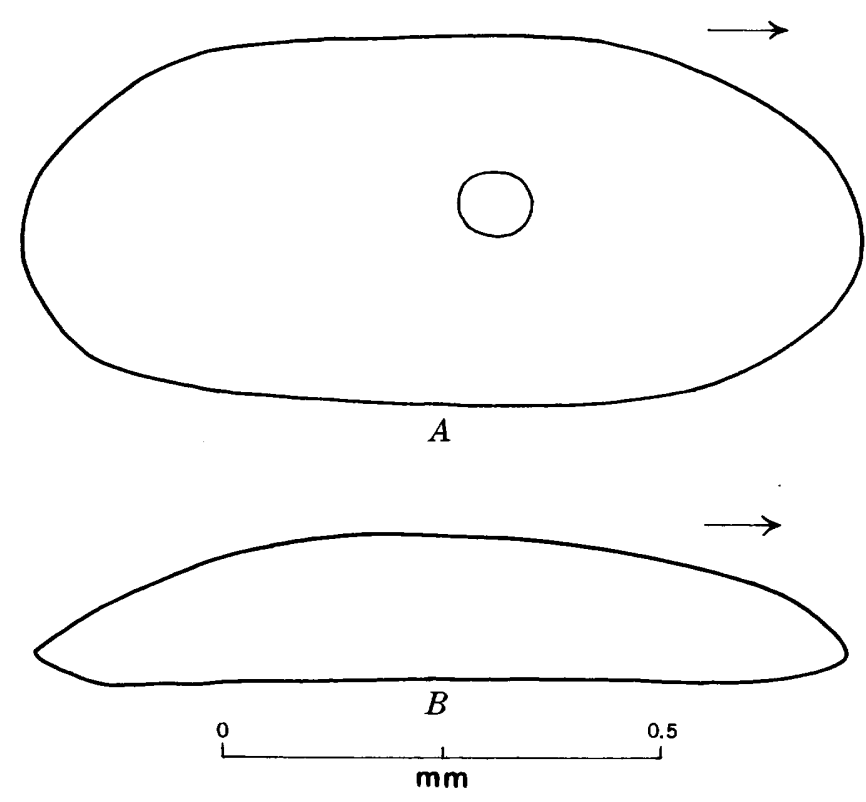

Figure 6.-Darwinula?.sp. 2. $A$, Exterior view of right valve; $B$, ventral view of right valve. Cumnock Formation, Upper Triassic, Bethany Church, near Gulf, N.C. USNM 177716, 177719.
Darwinula? sp. 3

Plate 1, figure 10 ; text figure 7

Shell elongate-subovate in side view, highest posteriorly; dorsal margin gently convex; ventral margin a little more strongly convex than dorsum; anterior margin narrowly rounded; posterior margin more broadly rounded, subtruncate below; valves moderately convex; surface smooth. Internal features not observed.

Length of figured right valve specimen $0.65 \mathrm{~mm}$, height $0.33 \mathrm{~mm}$, width of valve $0.07 \mathrm{~mm}$.

Remarks.-The shortened subovate outline of this form distinguishes it from other Darwinula in the collection. It does not appear to be an immature molt, but the internal structure is not known, and the species cannot be definitely classified.

Occurrence.-Rare in Cumnock Formation, Upper Triassic, Bethany Church locality, 0.5 mile west of Gulf, Chatham County, N.C.

Number of specimens studied.-Two.

Figured specimen.-USNM 177730.
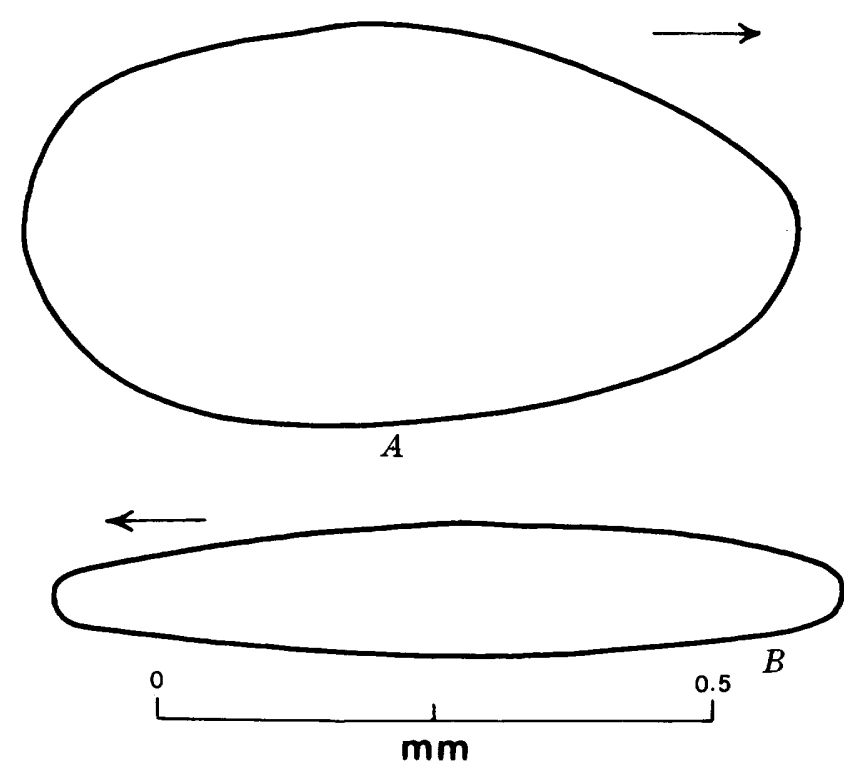

FiguRe 7.-Darwinula? sp. 3. A, Exterior view of right valve; $B$, dorsal view of right valve. Cumnock Formation, Upper Triassic, Bethany Church, near Gulf, N.C. USNM 177730.

\section{Darwinula? sp. 4}

Plate 1, figure 11; text figure 8

Shell subtriangular-sublanceolate in side view, highest anteromedially; dorsal margin strongly convex; ventral margin slightly convex; anterior mar- 


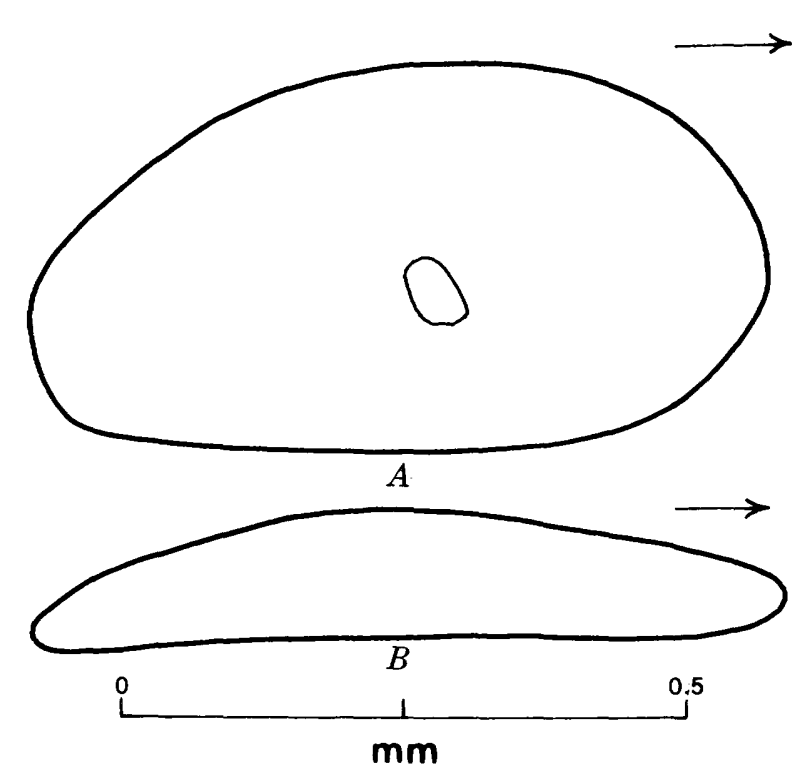

Figure 8.-Darwinula? sp. 4. $A$, Exterior view of right valve; $B$, ventral view of right valve. Cumnock Formation, Upper Triassic, Bethany Church, near Gulf, N.C. USNM 177731.

gin rounded, truncate above; posterior narrowly rounded, extended below; valves moderately convex; surface smooth. Internal structures not seen.

Length of figured right valve $0.68 \mathrm{~mm}$, height $0.35 \mathrm{~mm}$, width of valve $0.10 \mathrm{~mm}$.

Relationships.-This species is distinguished from others in the collection by its narrowly rounded and extended posterior margin and convex dorsum.

Occurrence.-Rare in Cumnock Formation, Upper Triassic, Bethany Church locality, 0.5 mile west of Gulf, Chatham County, N.C.

Number of specimens studied.-Three.

Figured specimen.-USNM 177731.

\section{Superfamily CYTHERACEA Baird, 1850 Family BYTHOCYTHERIDAE Sars, 1926}

\section{Genus MONOCERATINA Roth, 1928}

Monoceratina Roth, 1928, Jour. Paleontology, v. 2, p. 15.

Bythocytheremorpha Mandelstam, 1958, in Abushik and others, Microfauna USSR, v. 9, All-Union Petroleum Scientific Research Geol. Exploration Inst. Leningrad (VNIGRI) Trans., n.s., no. 115, p. 274.

Shell elongate subquadrate, small; dorsum straight; venter convex, with alate to subalate ventromedian expansion of surface; anterior broadly curved; posterior typically narrower; in addition to ventral expansion, surface may be lobate, sulcate, or pitted. Hinge of right valve a longitudinal furrow perhaps with terminal small hinge teeth and sockets; inner lamellae may be present; adductor muscle scar a median arcuate row of four or five spots with two more-anterior spots.

Type species.-Monoceratina ventrale Roth, 1928.

Geologic range.-Devonian to Holocene.

\section{Monoceratina? sp.}

Plate 3, figure 2; text figure 9

Shell subtrapezoidal in side view, highest posteromedially; hinge margin short, nearly straight but sinuous about half of shell length, with broadly obtuse cardinal angles; ventral margin straight and longer than dorsum; anterior margin curved, extended below, truncate above; posterior margin extended medially, truncate above as well as below. Valves with moderately broad rim around entire periphery and with a furrow defining its inner side; a low ventromedian longitudinal ridge extends from near anterior margin to above one-fourth from posterior end, anterodorsally is a low node; general surface within median ridge coarsely pitted.

Inner lamellae of moderate width as seen by transmitted light; radial canals few and widely spaced; hingement and musculature not seen owing to conditions of preservation.

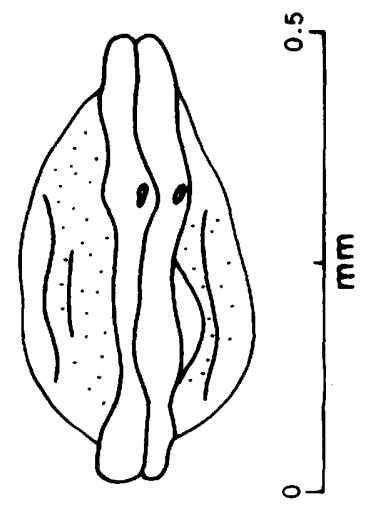

FIGURE 9.-Monoceratina? sp. Dorsal view of shell. Unit G. NCHY-OT-11 well, 5,016-5,026 feet.

Length of figured shell $0.40 \mathrm{~mm}$, height $0.28 \mathrm{~mm}$, width $0.26 \mathrm{~mm}$.

Relationships.-This form is somewhat like Monoceratina longispina (Bosquet, 1854) from the Senonian of Luxemburg, but has a shorter posteroventral spine than that species. The knowledge of its internal shell features is too incomplete to allow definite generic assignment. 


\author{
Occurrence.- \\ Unit $\mathrm{G}$ : \\ NC-HY-OT-11, 5,016-5,026 feet (sec- \\ tion $G^{\prime}-G^{\prime \prime}$, pl. 30)
}

Number of specimens studied.-Two.

Figured specimen.-USNM 177632.

\section{Genus PSEUDOBYTHOCYTHERE Mertens, 1956}

Pseudobythocythere Mertens, 1956, Geol. Jahrb., v. 72, p. 200.

Shell small, subquadrate to subpyriform; dorsum straight to sinuous, cardinal angles obtuse; venter gently convex; anterior broadly curved; posterior narrowly curved, extended above; surface with dorsomedian sulcus, anteromedian node, posteromedian swelling, ventral expansion of surface; reticulate, pitted, or smooth ornamentation. Hinge antimerodont, with terminal elongate crenulate sockets and intervening crenulate bar in left valve; adductor muscle scar an anteromedian row of four spots and a more anterior crescentic spot; inner lamellae fairly broad, radial canals simple and widely spaced:

Type species.-Pseudobythocythere goerlichi Mer. tens, 1956.

Geologic range.-Lower Cretaceous.

\section{Pseudobythocythere? sp.}

Plate 3 , figure 3 ; text figure 10

Shell subpyriform in side view, highest one-fourth from anterior end; dorsal margin sinuous, concave medially; ventral margin gently convex; anterior margin broadly curved, slightly extended below; posterior margin bluntly pointed, strongly extended medially; left valve larger than right, overlapping and extending beyond right in cardinal areas of dorsum; greatest convexity ventral in position. Ventral surface expanded as a low ala and overhangs ventral margin of valve, providing a wedgeshaped outline in end view; anterodorsally is a low lobe not reaching to dorsal margin, on each side of which is an oblique short sulcus; posterior sixth of shell sharply compressed and provided with low marginal rim; anterior margin with low rim; general surface ornamented by reticulating ridges in which a longitudinal ventrally curved sweep forms a dominant pattern.

Internal structures mostly not observed. Hinge seems to consist of terminal elongate crenulate teeth in right valve and corresponding sockets in left valve.

Length of shell $0.47 \mathrm{~mm}$, height $0.27 \mathrm{~mm}$, width $0.30 \mathrm{~mm}$.
Relationships.-The shape, sulcation, and general surface ornamentation relate this species to Pseudobythocythere. It is more convex, more coarsely pitted, and lacks the narrow ventral longitudinal ridge of $P$. goerlichi Mertens, 1956, the type species.

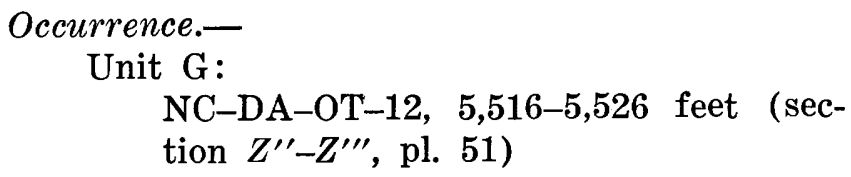

Number of specimens studied.-Two.

Figured specimen.-USNM 177633.

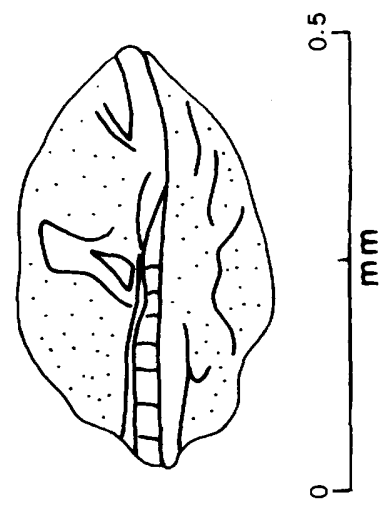

FIgURE 10.-Pseudobythocythere? sp. Dorsal view of shell. Unit G. NC-DA-OT-12 well, 5,516-5,526 feet.

Family CYTHERIDEIDAE Sars, 1925

Subfamily DOLOCYTHERIDEINAE Mandelstam, 1960

\section{Genus DOLOCYTHERIDEA Triebel, 1938}

Cytheridea (Dolocytheridea) Triebel, 1938, Senckenbergiana, v. 20, p. 494 .

Shell subovate to subelliptical; dorsum gently convex to nearly straight or truncated; venter gently convex to straight; anterior more broadly rounded than posterior; left valve larger than right; surface smooth or weakly pitted. Hinge of left valve has terminal crenulate sockets in Neocomian species, becoming smooth in Albian-Aptian species, and a short interterminal furrow; inner lamella broad anteriorly, vestibule small or absent; radial canals moderate in number; adductor muscle scar an anteromedian vertical row of four spots and two additional more-anterior spots, upper one trilobate. Brackish water to marine.

Type species.-Cytherina hilseana Roemer, 1840.

Geologic range.-Lower Cretaceous. 
Remarks.-The species of Dolocytheridea housed in the British Museum (Natural History) were studied because that genus has been recorded only infrequently in the United States.

Hypotype specimens of Dolocytheridea bosquetiana (Jones and Hinde, 1890), Gault (Albian), Folkestone and Maidstone, Kent and from ChalkMarl (Cenomanian) at Charing, Kent, are very similar to specimens of $D$. ? bosquetoidea $\mathrm{n}$. sp. from North Carolina, and the specimens may be conspecific. D. hilseana (Roemer, 1840) (Triebel, 1938), Lower Hauterivian, Speeton, Yorkshire, resembles an Asciocythere in shell outline but has the hinge of Dolocytheridea.

Dolocytheridea intermedia Oertli, 1958, lower and middle Barremian, Speeton, Yorkshire, has weakly denticuled hinge like that of Asciocythere, but other internal shell features are like those of Dolocytheridea. D. minuta Kaye, 1963, lower Barremian and Aptian, is a small form with flangelike compressed anterior margin, and is of uncertain generic position. D. typica Kaye, 1965 (1965b), in Gault, Pinhay, Devon, is a compressed elongate form with extended anterior margin, the duplicature is broad anteriorly, and radial canals are numerous. D. wolburgi Neale, 1962, Valanginian, Speeton, Yorkshire, is a large heavy-shelled form with a strong hinge.

\section{Dolocytheridea? bosquetoidea Swain and Brown, n. sp.}

Plate 3, figures 6, 7; text figure 11

Diagnosis.-An elongate questionable Dolocytheridea characterized by narrow posterior, concave venter, and scattered posterior small pits on surface.

Description.-Shell elongate-subovate to subelliptical in side view, highest medially; dorsal margin gently convex; ventral margin somewhat concave medially to posteromedially; anterior margin broadly curved, slightly extended below; posterior margin of female shell (pl. 3, fig. 7) a little narrower than anterior, that of male shell (pl. 3, fig. 6) much narrower than anterior and strongly extended below. Left valve larger than right, overlapping and extending slightly beyond it. Valves compressed; surface nearly smooth, with scattered small pits in posterior part.

Internal features as seen by transmitted light; inner lamellae narrow; radial canals not clearly observed; muscle scar an anteromedian vertical row of four oval closely spaced spots and a more-anterior irregular spot.
Length of female holotype shell (USNM 177635, pl. 3, fig. 7) $0.87 \mathrm{~mm}$, height $0.44 \mathrm{~mm}$, width 0.37 mm. Type locality, NC-HY-OT-11 well, Hyde County, N.C.; type horizon Unit G, 5,096-5,106 feet.

Relationships.-The species is similar to $D$. bosquetiana (Jones and Hinde, 1890) from the Gault of England in general shape, but is more elongate than that species. Lack of knowledge of the hingement makes the generic identity uncertain.

\section{Occurrence.-}

Unit $\mathrm{G}$ :

NC-DA-OT-12, 5,406-5,416 feet (section $Z^{\prime \prime}-Z^{\prime \prime \prime}$, pl. 51)

NC-HY-OT-11, 5,096-5,106 feet (section $G^{\prime}-G^{\prime \prime}$, pl. 30 )

Unit $\mathrm{F}$ :

NC-HY-OT-11, 4,456-4,466 feet (section $G^{\prime}-G^{\prime \prime}$, pl. 30 )

NC-CAR-OT-11, 2.635-2,645, feet (Non-section well)

NC-CAR-OT-11, 2,734-2,744 feet (section $X-X^{\prime}$, pl. 46)

Unit $\mathrm{E}$ :

NC-CAR-OT-11, 2,506-2,536 feet (section $X-X^{\prime}$, pl. 46)

Number of specimens studied.-25+.

Figured specimens.-USNM 177634, 177635 (holotype).

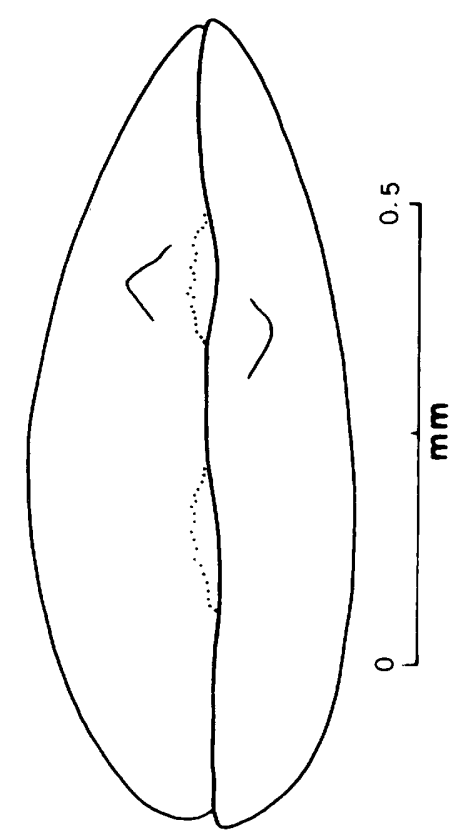

Figure 11.-Dolocytheridea? bosquetoidea Swain and Brown, $\mathrm{n}$. sp. Dorsal view of holotype (USNM 177635). Unit G. NCHY-OT-11 well, 5,096-5,106 feet. 
Dolocytheridea oertlii Swain and Brown, n. sp.

Plate 3, figures 4,5

Diagnosis.-A Dolocytheridea having rather strongly arched dorsum is presumed to be a male shell with truncate posterodorsal slope; female shells show a more fully developed posterodorsal slope; surface has scattered weak pits.

Description.-Shell elongate-subelliptical in side view, highest medially; dorsal margin moderately convex; ventral margin slightly concave medially; anterior margin broadly curved; posterior margin also broadly curved, slightly truncate medially. Left valve much larger than right, overlapping and extending beyond right around most of periphery. Valves moderately convex. Surface bears scattered weak pits.

Hinge not clearly seen but appears to be merodont; muscle scar pattern not seen; inner lamellae appear to be narrow in transmitted light, and radial canals relatively few.

Length of holotype shell (USNM 177637, pl. 3, fig. 5) $0.95 \mathrm{~mm}$, height $0.53 \mathrm{~mm}$, width $0.42 \mathrm{~mm}$. Type locality, NC-HY-OT-11 well, Hyde County, N.C.; type horizon Unit F, 4,366-4,376 feet.

Relationships.-The species is similar to Dolocytheridea intermedia Oertli, 1958, from the lower Albian of France in general outline, but has a more arched dorsal margin and more distinctly pitted surface. The species is named for Dr. H. J. Oertli.

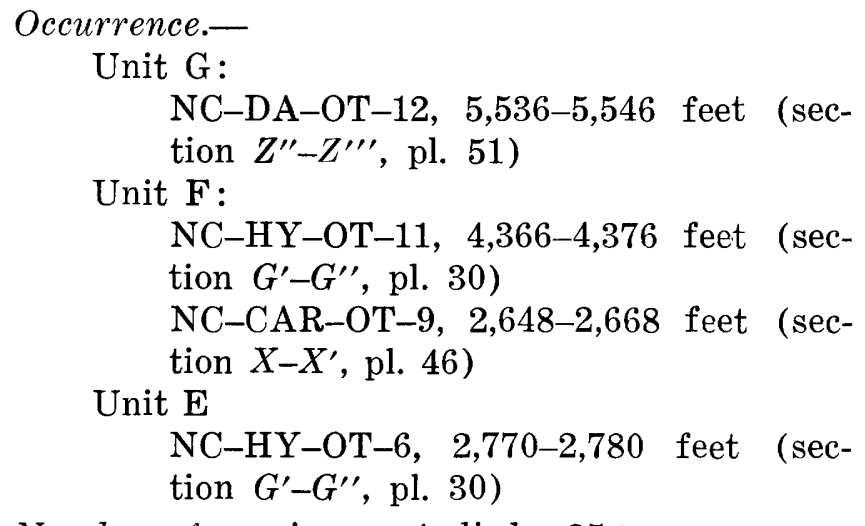

Number of specimens studied.-25+.

Figured specimens._USNM 177636, 177637 (holotype).

\section{Genus ASCIOCYTHERE Swain, 1952}

Asciocythere Swain, 1952, U.S. Geol. Survey Prof. Paper 234-B, p. 75.

Shell small, subovate; dorsum and venter moderately to weakly convex; ends broadly and nearly equally rounded; left valve larger than right; valves moderately convex; surface smooth, pitted, or with irregular ridges. Hinge of left valve with terminal elongate crenulate sockets and intervening smooth or denticulate bar, and with a well-defined accommodation groove; inner lamellae narrow, vestibule very narrow or absent; radial canals numerous, occurring around entire free margin; adductor muscle scar an anteromedian vertical row of four spots and two additional more-anterior spots.

Type species.-Bythocypris rotundus Vanderpool, 1928.

Geologic range.-Upper Jurassic (?), Lower Cretaceous, Upper Cretaceous.

\section{Asciocythere elongata Swain and Brown, n. sp.}

Plate 5, figures 3, 5-7

Asciocythere? cf. A.? amygdaloides (Cornuel). Swain, 1952, U.S. Geol. Survey Prof. Paper 234-B, p. 76, pl. 8, figs. 37-39.

Diagnosis.-A species of Asciocythere having elongate-ovate outline, weak anterior submarginal groove, and posterior submarginal ridge; general surface smooth.

Description.-Shell elongate-ovate in lateral view, highest slightly anterior to middle; dorsal margin moderately convex; ventral margin slightly convex and sinuous; anterior margin broadly curved, slightly extended below. Left valve larger than right, overlapping and extending beyond right around entire periphery. Valves moderately convex. Surface smooth; right valve with shallow groove parallel to anterior margin and with posterior submarginal low ridge.

Inner lamellae narrow as seen in transmitted light, no radial canals observed; hingement appears similar to that of Asciocythere; muscle scar not seen.

Length of holotype shell (USNM 177638, pl. 5, fig. 3) $0.90 \mathrm{~mm}$, height $0.43 \mathrm{~mm}$, width $0.35 \mathrm{~mm}$. Type locality, NC-HY-OT-11 well, Hyde County, N.C.; type horizon Unit G, 5,286-5,296 feet.

Relationships.-This species is more elongate than A. rotunda (Vanderpool, 1928) but is otherwise similar to it. It is one of the most abundant ostracodes in Unit G.

\section{Occurrence.-}

Unit $\mathrm{G}$ :

NC-HY-OT-11, 5,286-5,296 feet and $5,386-5,396$ feet (section $G^{\prime}-G^{\prime \prime}$, pl. 30) NC-DA-OT-11, 4,426-4,436 feet (section $Z^{\prime \prime}-Z^{\prime \prime \prime}$, pl. 51)

NC-DA-OT-10, 6,096-6,106 feet (section $G^{\prime}-G^{\prime \prime}$, pl. 30 ) 


\author{
MD-WOR-OT-11, 5,017-5,037 feet (sec- \\ tion $M-M^{\prime}$, pl. 35) \\ Unit $\mathrm{F}$ : \\ NC-HY-OT-11, 4,456-4,466 feet (sec- \\ tion $G^{\prime}-G^{\prime \prime}$, pl. 30 ) \\ Number of specimens studied.-25+ \\ Figured specimens.-USNM 177638 (holotype),
} 177639, 177640, 177641.

\section{Asciocythere macropunctata Swain}

Plate 4, figures 7-10; plate 5, figures 1, 2; text figure 12

[?]Cytheridea ovata. Bosquet. Veen, 1935, Natuurh. Maandblad, v. 24 , p. 106, pl. 3, figs. 1-24.

Asciocythere macropunctata Swain, 1952, U.S. Geol. Survey Prof. Paper 234-B, p. 77, pl. 8, fig. 21.

Howe and Laurencich, 1958, Introd. study Cretaceous Ostracoda, p. 60.

Shell subovate, highest medially; dorsum strongly convex; venter slightly convex to nearly straight; anterior rounded, extended medially; posterior narrower, extended below; left valve larger than, overlapping and extending beyond, right; valves not strongly convex, surface rises rather abruptly from valve edges; numerous pits ornament surface; interspaces about two to four times width of pits. Presumed male shells shorter and relatively higher than females.

Hinge of left valve with terminal elongate faintly crenulate sockets and interterminal noncrenulate bar, dorsal to which is an accommodation groove. Inner lamellae narrow, no vestibule; radial canals fairly numerous, mostly straight but not perpendicular to inner margin anteriorly. Muscle scar not clearly seen but apparently consists of an anteromedian vertical row of four spots and two additional more-anterior spots, the lower one of which has an inverted-comma shape.

Length of a figured female shall (USNM 177653, pl. 4, fig. 7) $0.63 \mathrm{~mm}$, height $0.42 \mathrm{~mm}$, width 0.32 $\mathrm{mm}$.

Remarks.-Several of the present specimens are more pointed posteriorly than had been observed previously.

Occurrence.-

Unit F :

NC-DA-OT-11, 2,696-2,706 feet (section $Z^{\prime \prime}-Z^{\prime \prime \prime}$, pl. 51)

Unit $\mathrm{E}$ :

NC-HY-OT-6, 2,780-2,790 feet (sec-

Unit $\mathrm{D}$ : tion $G^{\prime}-G^{\prime \prime}$, pl. 30 )

NC-HY-OT-6, 2,330-2,340 feet (section $G^{\prime}-G^{\prime \prime}$, pl. 30)
Unit $\mathrm{C}$ :

NC-HY-OT-11, 2,906-2,916 feet (section $G^{\prime}-G^{\prime \prime}$, pl. 30 )

NC-DA-OT-10, 3,668-3,678 feet* (section $G^{\prime}-G^{\prime \prime}$, pl. 30 )

Number of specimens studied.-25+.

Figured specimens.-USNM 177653, 177654, 177655, 177656, 177657, 177658 .

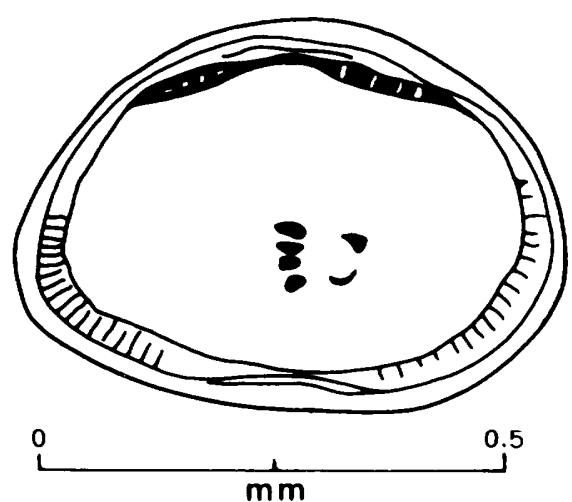

Figure 12.-Asciocythere macropunctata Swain. Interior view of left valve. Unit C. NC-HY-OT-11 well, 2,9362,946 feet.

\section{Asciocythere rotunda (Vanderpool)}

Plate 4, figures 3-6

Bythocypris rotundus Vanderpool 1928, Jour. Paleontology, v. 2, p. 102, pl. 13, figs. 5. 6.

Vanderpool, 1930, Jour. Paleontology, v. 4, p. 257.

[?]Cytheridea amygdaloides brevis (Cornuel). Alexander, 1929, Univ. Texas Bull. 2907, p. 70, pl. 4, fig. 13.

Cytheridea cf. rotundus (Vanderpool). Vanderpool, 1933, Jour. Paleontology, v. 7, p. 411.

Asciocythere rotunda (Vanderpool). Swain, 1952, U.S. Geol. Survey Prof. Paper 234-B, p. 76, pl. 8, figs. 22-23.

Howe and Laurencich, 1958, Introd. study Cretaceous Ostracoda, p. 61.

Shell subovate, highest submedially, dorsum convex; venter slightly convex, somewhat sinuous; anterior more broadly curved than posterior; valves convex, greatest thickness median; left valve larger than and overlaps right, overreaching right around most of periphery; surface smooth except for widely separated small pits; right valve in well-preserved specimens bears a weak groove parallel to anterior margin and a faint ridge along ventral part of posterior margin.

Left valve hinge with anterior elongate denticulate socket, interterminal high bar, and posterior denticulate socket; accommodation groove lies dorsal to median bar. Inner lamellae narrow, line of 
concrescence and inner margin coincide; adductor muscle scar an anteromedian vertical row of four spots and a more-anterior larger spot.

Length of figured specimen (USNM 177651, pl. 4, fig. 5) $0.68 \mathrm{~mm}$, height $0.45 \mathrm{~mm}$, width $0.38 \mathrm{~mm}$.

Occurrence.-

Unit $\mathrm{G}$ :

NC-HY-OT-11, 5,416-5,426 feet and

$5,286-5,296$ feet (section $G^{\prime}-G^{\prime \prime}$, pl. 30 )

NC-CAR-OT-6, 3,490-3,500 feet (sec-

tion $X-X^{\prime}$, pl. 46 )

NC-CAR-OT-7, 4,020-4,030 feet (sec-

tion $D-D^{\prime}$, pl. 26)

NC-CAR-OT-8, 3,341-3,351 feet (sec-

tion $D-D^{\prime}$, pl. 26)

NC-DA-OT-12, 5,416-5,426 feet (sec-

tion $Z^{\prime \prime}-Z^{\prime \prime \prime}$, pl. 51)

NC-DA-OT-10, 6,275-6,285 feet* (sec-

tion $Z^{\prime \prime}-Z^{\prime \prime \prime}$, pl. 51)

NC-DA-OT-9, 5,239-5,249 feet* (sec-

tion $Z^{\prime \prime}-Z^{\prime \prime \prime}$, pl. 51)

NC-DA-OT-14, 4,619-4,629 feet (sec-

tion $F-F^{\prime}$, pl. 28)

NC-PAM-OT-3, 3,353-3,363 feet (sec-

tion $E-E^{\prime}$, pl. 27)

NJ-CM-OT-1, 4,358-4,368 feet (section $\left.O-O^{\prime}, \mathrm{pl}, 37\right)$

Unit $\mathrm{F}$ :

NC-HY-OT-11, 4,426-4,436 feet (section $G^{\prime}-G^{\prime \prime}$, pl. 30 )

This is one of the most abundant ostracode species in Unit $\mathrm{G}$. The one specimen recovered from Unit $F$ may be reworked from Unit $G$.

Number of specimens studied.-25+

Figured specimens.-USNM 177649, 177650, 177651, 177652 .

\section{Asciocythere? rugosa Swain and Brown, n. sp.}

Plate 3, figures 8-12; plate 4, figures 1, 2; text figure 13

Diagnosis.-An Asciocythere-like species in shape with vermicular surface ornamentation, faintly bisulcate anterodorsally.

Description.-Shell of male short and high, that of female more elongate, subovate in side view, highest medially; dorsal margin convex; ventral margin nearly straight to slightly convex; anterior margin broadly curved, slightly extended below; posterior margin more narrowly curved and extended below. Left valve larger than right, overlapping and overreaching right around entire margin. Valves moderately convex; surface, except smooth marginal zones bears shallow, irregular, closely spaced pits in a vermicular pattern; anterodorsal area of wellpreserved shells faintly bisulcate.

Inner lamellae narrow as seen by transmitted light; no radial canals visible; hinge not clearly seen but appears to be that of Asciocythere; muscle scar not observed.

Length of holotype shell (USNM 177643, pl. 3, fig. 9) $0.68 \mathrm{~mm}$, height $0.45 \mathrm{~mm}$, width $0.34 \mathrm{~mm}$. Type locality, NC-HY-OT-11 well, Hyde County, N.C.; type horizon Unit G, 5,016-5,026 feet.

Relationships.-Although related to them in general form, the peculiar vermicular pitting of the surface of this species separates it from other described species of Asciocythere; because knowledge of the internal shell characteristics is incomplete, the generic assignment is somewhat uncertain.

Occurrence.-

Unit G:

NC-HY-OT-11, 4,986-4,996 feet and 5,016-5,026 feet (section $G^{\prime}-G^{\prime \prime}$, pl. 30)

Number of specimens studied.-25+.

Figured specimens.-USNM 177642 (paratype), 177643 (holotype), 177644 (paratype), 177645 (paratype), 177646 (paratype), 177647 (paratype), 177648 (paratype).

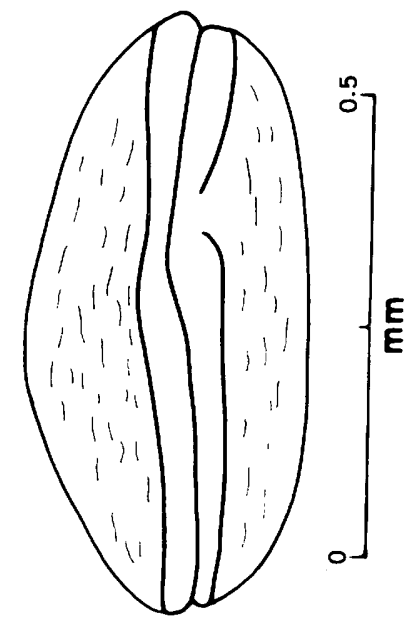

FIgURE 13.-Asciocythere? rugosa Swain and Brown, n. sp. Dorsal view of holotype (USNM 177643). Unit G. NC-HY-OT-11 well, 5,016-5,026 feet.

\section{Asciocythere triangularis Swain}

Asciocythere? triangularis Swain, 1952, U.S. Geol. Survey Prof. Paper 234-B, p. 77, pl. 8, fig. 34 .

Although questionably assigned to the genus originally, we now believe the species in the pres- 
ent collections has the form of carapace and internal shell structures of Asciocythere.

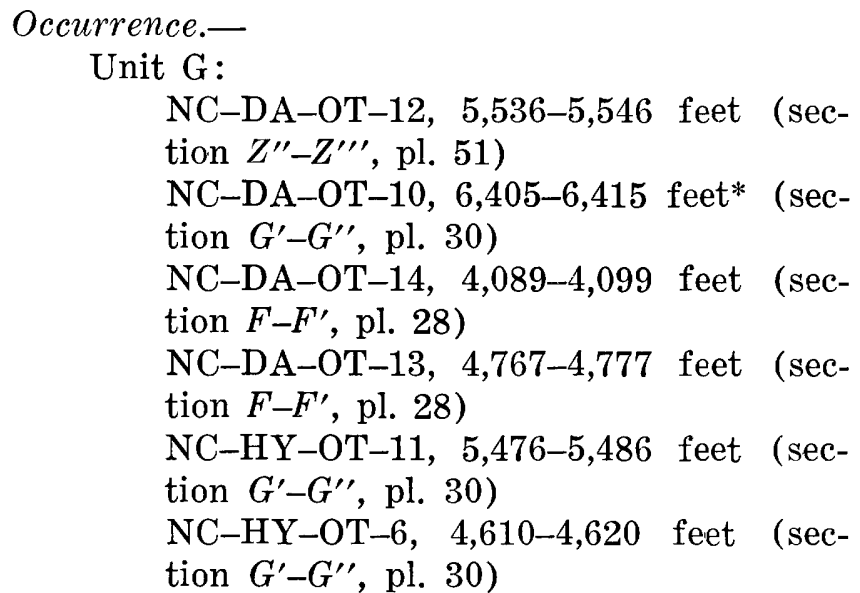

Number of specimens studied.-Six.

\section{Subfamily CYTHERIDEINAE Sars, 1925}

\section{Genus OVOCYTHERIDEA Grekoff, 1951}

Ovocytheridea Grekoff, 1951, Rev. Inst. française Petrole et Annales Combust. Liquides, v. 6, p. 56.

Shell subovate to subtriangular; dorsum moderately to strongly convex; venter nearly straight to slightly convex; anterior margin more broadly curved than posterior margin; sides typically subparallel in dorsal view; surface smooth or pitted; left valve larger than right valve. Hinge of right valve with crenulated elongate teeth and intervening crenulated furrow; adductor muscle scar a vertical row of four spots and a more-anterior spot opposite dorsal end of main group; inner lamellae narrow; radial pore canals straight.

Type species.—Ovocytheridea nuda Grekoff, 1951.

Geologic range.-Cretaceous.

\section{Ovocytheridea? sp.}

Plate 5, figure 4

Shell subtriangular in side view, highest medially; dorsal margin strongly convex, umbonate; ventral margin nearly straight, slightly concave anteromedially; anterior margin broadly curved, slightly extended below; posterior margin narrowly rounded, strongly extended below; left valve larger than right, overlapping and extending beyond right most strongly along ventral margin; valves moderately convex; surface smooth; internal features unknown.

Length of shell $0.72 \mathrm{~mm}$, height $0.44 \mathrm{~mm}$, width $0.38 \mathrm{~mm}$.
Relationships.-The species is very similar to Ovocytheridea producta Grekoff, 1952, from the Senonian of North Africa but has weaker dorsal overlap of the right valve by the left and is somewhat more elongate than that species.

\section{Occurrence.-}

Unit $\mathrm{G}$ :

NC-HY-OT-11, 5,016-5,026 feet and $5,096-5,106$ feet. (section $G^{\prime}-G^{\prime \prime}$, pl. 30)

Number of specimens studied.-Two.

Figured specimen.-USNM 177659.

\section{Genus FOSSOCYTHERIDEA Swain and Brown, 1964}

Fossocytheridea Swain and Brown, 1964, North Carolina Dept. Conserv. and Devel. Bull. 78, p. 17.

A description of the genus was recently given (Swain and Brown, 1964).

Type species.-Fossocytheridea lenoirensis Swain and Brown, 1964.

Geologic range.-Cretaceous.

\section{Fossocytheridea lenoirensis Swain and Brown}

Plate 6, figures 1-3

Fossocytheridea lenoirensis Swain and Brown, 1964, North Carolina Dept. Conserv. and Devel. Bull. 78, p. 20, pl. 1, figs. $11 \mathrm{a}-\mathrm{h}$; pl. 2 , figs. $1 \mathrm{a}-\mathrm{j}, 2$; text figs. $5 \mathrm{a}$, b.

The species was described previously from beds now included in Unit $F$.

\section{Occurrence.-}

Unit $\mathbf{F}$ :

NC-BEA-OT-11, 1,400-1,410 feet (section $X-X^{\prime}$, pl. 46 )

NC-BEA-OT-12, 1,475-1,485 feet (section $X-X^{\prime}$, pl. 46)

NC-BEA-OT-13, 1,534-1,544 feet (section $X-X^{\prime}$, pl. 46)

NC-CAM-OT-10, 1,344-1,354 feet (section $W-W^{\prime}$, pl. 45)

NC-CR-OT-30, 2,099-2,109 feet (sec-

tion $D-D^{\prime}$, pl. 26)

NC-CAR-OT-5, 3,382-3,392 feet (sec-

tion $E-E^{\prime}$, pl. 27)

NC-CAR-OT-6, 2,810-2,820 feet (sec-

tion $X-X^{\prime}$, pl. 46)

NC-CAR-OT-7, 3,230-3,240 feet (section $D-D^{\prime}$, pl. 26)

NC-CAR-OT-8, 2,741-2,751 feet (section $D-D^{\prime}$, pl. 26)

NC-CAR-OT-9, 2,648-2,658 feet (section $X-X^{\prime}$, pl. 46)

NC-CAR-OT-11, 2,734-2,744 feet (section $X-X^{\prime}$, pl. 46) 
NC-CAR-OT-12, 2,657-2,667 feet (section $E-E^{\prime}$, pl. 27)

NC-DA-OT-11, 2,706-2,716 feet (section $Z^{\prime \prime}-Z^{\prime \prime \prime}$, pl. 51)

NC-DA-OT-13, 3,386-3,396 feet (section $F-F^{\prime}$, pl. 28)

NC-DA-OT-14, 2,589-2,599 feet (section $F-F^{\prime}$, pl. 28 )

NC-HAL-T-2, 172-182 feet (section $U-U^{\prime}$, pl. 43)

NC-HAL-T-13, 110-115 feet and 125130 feet (Non-section well)

NC-HY-OT-6, 3,373-3,383 feet (section $G^{\prime}-G^{\prime \prime}$, pl. 30)

NC-JON-OT-4, 1,040-1,050 feet (section $D-D^{\prime}$, pl. 26)

NC-LEN-P-4, 667-677 feet (section $E-E^{\prime}$, pl. 27)

NC-NH-OT-15, 1,461-1,471 feet (section $Z-Z^{\prime}$, pl. 49)

NC-NH-T-16, 975-985 feet (section $B-B^{\prime}$, pl. 24)

NC-NOR-T-12, 102-112 feet (section $G-G^{\prime}$, pl. 29)

NC-ON-OT-10, 1,378-1,388 feet (sec-

tion $D-D^{\prime}$, pl. 26)

NC-ON-OT-11, 1,170-1,180 feet (sec-

tion $D-D^{\prime}$, pl. 26)

NC-ON-OT-22, 1,135-1,145 feet (sec-

tion $C-C^{\prime}$, pl. 25)

NC-ON-OT-23, 1,043-1,053 feet (sec-

tion $V-V^{\prime}$, pl. 44)

NC-ON-OT-24, 1,174-1,184 feet (sec-

tion $C-C^{\prime}$, pl. 25)

NC-ON-OT-25, 1,389-1,399 feet (sec-

tion $C-C^{\prime}$, pl. 25)

NC-PAM-OT-3, 2,543-2,553 feet (section $E-E^{\prime}$, pl. 27)

NC-PAM-OT-8, 2,244-2,254 feet (Nonsection well)

NC-PAM-OT-9, 2,498-2,508 feet (section $E-E^{\prime}$, pl. 27)

NC-PEN-OT-6, 937-947 feet (section $V-V^{\prime}$, pl. 44)

NC-PEN-OT-7, 1,309-1,319 feet (section $Z-Z^{\prime}$, pl. 49)

NC-PEN-OT-8, 1,228-1,238 feet (section $Z-Z^{\prime}$, pl. 49)

NC-PEN-OT-9, 1,156-1,166 feet (section $Z-Z^{\prime}$, pl. 49)

NC-PI-T-1, 581-591 feet (section $U-U^{\prime}$, pl. 43)

NC-WAS-OT-2, 1,624-1,634 feet (section $G^{\prime}-G^{\prime \prime}$, pl. 30)
VA-SO-P-3, 110-120 feet (section $X-X^{\prime}$, pl. 46)

Unit $\mathrm{C}$ :

NC-HY-OT-11, 2,936-2,946 feet (section $G^{\prime}-G^{\prime \prime}$, pl. 30)

Specimen in Unit $\mathrm{C}$ may be reworked from Unit F.

Number of specimens studied.- $50+$.

Figured specimens.-USNM 177660, 177661, 177662 .

\section{Genus PERISSOCYTHERIDEA Stephenson, 1938}

Perissocytheridea Stephenson, 1938, Jour. Paleontology, v. 12, p. 144.

Ilyocythere Klie, 1939, Zool. Jahrb., Abt. Fauna Systematik ökologie u. Geographie, Jena, v. 72, p. 364.

Iliocythere Hartmann, 1953, Zool. Anz., v. 151, p. 310 (misspelling of Ilyocythere).

Shell small, subovate to subpyriform; dorsum nearly straight to sinuous; venter nearly straight to slightly concave, convergent with dorsum; anterior broadly curved; posterior narrowly curved; left valve larger than right; surface with posterodorsal swelling, anterodorsal sulcuslike oblique depression; ventromedian longitudinal swelling, pits, reticulations, or ridges. Hinge of left valve with terminal elongate crenulate sockets and interterminal denticulate bar; inner lamellae narrow, radial canals short, fairly numerous; adductor muscle scar a vertical row of spots and more-anterior spots. Brackish water.

Type species.-Cytheridea matsoni Stephenson, 1935.

Geologic range.-Lower Cretaceous to Holocene.

\section{Perissocytheridea odomensis Swain and Brown}

Perissocytheridea odomensis Swain and Brown, 1964, North Carolina Dept. Conserv. and Devel. Bull. 78, p. 23, pl. 2 , figs. $7,8 \mathrm{a}, \mathrm{b}$; text fig. $6 \mathrm{~b}$.

The species was described from beds now included in Unit $\mathrm{F}$ in Northampton and Halifax Counties, N.C.

Occurrence.-

Unit $\mathrm{F}$ :

NC-DA-OT-12, 5,136-5,146 feet (section $Z^{\prime \prime}-Z^{\prime \prime \prime}$, pl. 51)

NC-HAL-T-13, 110-115 feet (Nonsection well)

Unit D :

NC-HY-OT-6, 2,330-2,340 feet (section $G^{\prime}-G^{\prime \prime}$, pl. 30 )

Number of specimens studied.-Six. 
Subfamily SCHULERIDEINAE Mandelstam, 1959

\section{Genus SCHULERIDEA Swartz and Swain, 1946}

Schuleridea Swartz and Swain, 1946, Jour. Paleontology, v. 20, p. 363.

Aequacytheridea Mandelstam, 1947, in Microfauna, Petrol. Occ., Cauc., Emba, and Central Asia, All-Union Petroleum Scientific Research Geol. Exploration Inst. (VNIGRI), (State Sci. Tech. Pub. House), LeningradMoscow, p. 247-248.

Shell subovate-subtriangular; dorsum moderately to strongly convex, left valve typically more or less umbonate, right valve truncated dorsally; venter slightly concave to nearly straight; anterior broadly curved; posterior narrow to acuminate; left valve larger than right; surface smooth or pitted; anterodorsal sulcus in right valve, much weaker in left valve. Hinge of right valve with terminal elongate crenulate teeth and intervening smooth bar, accommodation groove in left valve; adductor muscle scar a median vertical row of four spots and a moreanterior spot.

Type species.-Schuleridea acuminata Swartz and Swain, 1946.

Geologic range.-Upper Jurassic to Lower Cretaceous, Upper Cretaceous (?) to Miocene(?).

Remarks.-When Swartz and Swain (1946) described the genus, they had in mind the strongly umbonate, unevenly convex Jurassic forms with well-developed accommodation groove such as $S$. acuminata. Subsequently, the genus has been expanded to include almost any subtriangular cytherideid species that has a weak anterodorsal sulcus in the right valve and a "hemimerodont" type of hinge. The Schulerideas housed in the British $\mathrm{Mu}-$ seum were examined to learn more about the European concept of the genus.

Schuleridea alata Kaye, 1965 (1965a), upper Aptian, Chale Bay, Isle of Wight, possibly is a brachycytherid rather than Schuleridea, judging from its shape and alation. S. bilobata (Triebel, 1938), Middle Barremian, Speeton, Yorkshire (Kaye, 1963a), is a typical Cretaceous Schuleridea, more or less evenly convex. $S$. derooi Damotte and Grosdidier, 1963, Upper Aptian, Sutterby, Lincolnshire (Kaye and Barker, 1965), is a pitted form that appears to be dimorphic, one group of specimens being more elongate than the other.

S. dimorphica Kaye, 1965 (1965b), also includes elongate forms of uncertain generic position. $S$. hammi (Triebel, 1938), Upper Barremian, Speeton, Yorkshire (Kaye, 1963a), is coarsely pitted medially and has numerous radial canals. The right valve is more elongate than is typical for the genus.

S. jonesiana (Bosquet), Chalk Marl (Turonian?), Didcot Station, Berkshire (Jones and Hinde, 1890), also in Gault and Detritus (Albian and Cenomanian) of Kent is a form with highly arched dorsum but weak sulcus and may not belong to this genus. S. sulcata Kaye 1965 (1965a), Lower Aptian, Atherfield, Isle of Wight, is of small size; the angulated venter is like typical Schuleridea in sense of Swartz and Swain.

\section{Schuleridea anterofossulata Swain and Brown, n. sp.}

Plate 6, figures 4-7

Diagnosis.-A Schuleridea having strongly convex dorsum, anterior submarginal furrows, strong dorsal overreach of right valve by left, and finely and densely pitted surface.

Description.-Shell subtriangular, highest medially; dorsal margin strongly convex; posterior slope subtruncate; ventral margin slightly convex and sinuous; anterior margin broadly curved, slightly extended below; posterior margin narrowly curved, strongly extended below, truncate above. Left valve larger than right overlapping and overreaching right along dorsal, ventral, and posterior margins. Valves moderately convex, greatest convexity median. Anterodorsally on right valve is a low oblique eye tubercle. Anterior submarginal zone of right valve with two narrow furrows parallel to margin; general surface finely and densely pitted.

Hingement and other internal features not clearly seen in specimens at hand.

Length of holotype shell (USNM 177665, pl. 6, fig. 6) $0.75 \mathrm{~mm}$, height $0.47 \mathrm{~mm}$, width $0.37 \mathrm{~mm}$. Type locality, NC-DA-OT-11 well, Dare County, N.C.; type horizon Unit G, 4,606-4,616 feet.

Relationships.-This species resembles $S$. hatterasensis Swain, 1952, in general shape and in presence of anterior submarginal furrows on the right valve, but that species is more strongly umbonate and has greater dorsal overreach of the right valve by the left.

Occurrence.-

Unit G :

NC-DA-OT-11, 4,606-4,616 feet (section $Z^{\prime \prime}-Z^{\prime \prime \prime}$, pl. 51)

NC-DA-OT-12, 6,096-6,106 feet and 6,136-6,146 feet (section $Z^{\prime \prime}-Z^{\prime \prime \prime}$, pl. 51)

Number of specimens studied.-25+

Figured specimens.-USNM 177663(paratype), 177664 (paratype), 177665 (holotype), 177666 (paratype). 


\section{Schuleridea hatterasensis Swain}

Plate 6, figures 8,9 ; text figure 14

[?]Cytheridea (Haplocytheridea) aff. C. (H.) thoerenensis Triebel, 1938, Senckenbergiana, v. 20, p. 483, pl. 2, figs. 30-34.

Schuleridea hatterasensis Swain, 1952, U.S. Geol. Survey Prof. Paper 234-B, p. 74, pl. 9, figs. 35-38.

Shell subovoid; dorsum convex; venter gently convex; anterior more broadly curved than posterior, both ends slightly extended below; left valve considerably larger than right, slightly umbonate along hinge; convexity of valves moderate, greatest convexity posteromedian; anterior end of right

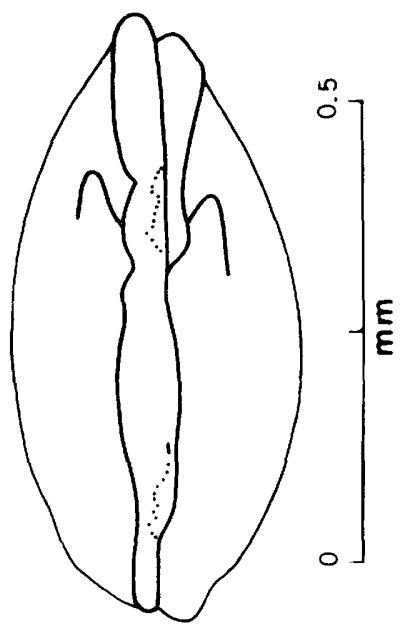

FIGURE 14.-Schuleridea hatterasensis Swain. Dorsal view of shell. Unit G. NC-DA-OT-12 well, $5,416-5,426$ feet.

valve compressed, that of left valve less strongly compressed; anterodorsal small eye tubercle and adjacent oblique sulcus; general surface finely pitted. Hinge of left valve comprises terminal elongate denticulate sockets and interterminal noncrenulate bar, dorsal of which is a wide accommodation groove; muscle scar a median vertical row of three to four spots; inner lamellae of moderate width; no vestibule.

Length of figured specimen (USNM 177669, pl. 6, fig. 8) $0.65 \mathrm{~mm}$, height $0.50 \mathrm{~mm}$, width $0.36 \mathrm{~mm}$.

Occurrence.-

Unit $\mathrm{H}$ :

NC-CAR-OT-7, 4,750-4,760 feet (section $D-D^{\prime}$, pl. 26)

NC-CAR-OT-6, 4,060-4,070 feet (section $X-X^{\prime}$, pl. 46)
NC-DA-OT-13，5,687-5,697 feet (section $Z^{\prime \prime}-Z^{\prime \prime \prime}$, pl. 51)

Unit $\mathrm{G}$ :

NC-CAR-OT-5, 4,582-4,592 feet (sec-

tion $E-E^{\prime}$, pl. 27)

NC-DA-OT-9, 5,309-5,319 feet* (sec-

tion $Z^{\prime \prime}-Z^{\prime \prime \prime}$, pl. 51)

NC-DA-OT-10, 6,275-6,285 feet* and

6,452-6,462 feet* (section $G^{\prime}-G^{\prime \prime}, \mathrm{pl} .30$ )

NC-DA-OT-12, 5,416-5,426 feet (sec-

tion $Z^{\prime \prime}-Z^{\prime \prime \prime}$, pl. 51)

NC-DA-OT-14, 3,919-3,,929 feet (sec-

tion $F-F^{\prime}$, pl. 28)

NC-HY-OT-6, 4,740-4,750 feet (sec-

tion $G^{\prime}-G^{\prime \prime}$, pl. 30)

NC-HY-OT-11, 5,036--5,046 feet (section $G^{\prime}-G^{\prime \prime}$, pl. 30)

Number of specimens studied.-25+.

Figured specimens._USNM 177669, 177670.

\section{Schuleridea? lacustris Swain}

Plate 6, figure 10

Schuleridea? lacustris Swain, 1952, U.S. Geol. Survey Prof. Paper 234-B, p. 74, pl. 9, fig. 48.

Occurrence.-

Unit $\mathrm{H}$ :

NC-DA-OT-13, 5,687-5,697 feet (section $Z^{\prime \prime}-Z^{\prime \prime \prime}$, pl. 51)

Unit $\mathrm{G}$ :

NC-DA-OT-9, 4,949-4,959 feet* (section $Z^{\prime \prime}-Z^{\prime \prime \prime}$, pl. 51)

Number of specimens studied.-Two.

Figured specimen.-USNM 177668.

\section{Schuleridea? sp.}

Plate 7, figure 1; text figure 15

Shell subovate-subtriangular in side view, highest anterior to middle; dorsal margin strongly convex, subangulate at position of greatest height; ventral margin gently convex, straightened posteromedially; anterior margin broadly curved; posterior margin narrowly curved, extended below. Valves moderately convex, greatest convexity median. Left valve slightly larger than and extending beyond right. Surface weakly and sparsely pitted; anterodorsally on each valve is a small eye tubercle which is defined ventrally by a shallow furrow.

Hinge of left valve as seen by transmitted light consists of terminal crenulate grooves and intervening bar in left valve and corresponding teeth and 
groove in right valve; inner lamellae moderately wide; radial pore canals not clearly seen but do not seem to be numerous; adductor muscle scar not observed.

Length of figured shell $0.75 \mathrm{~mm}$, height $0.47 \mathrm{~mm}$, width $0.33 \mathrm{~mm}$.

Relationships.-The general shape, overlap, eye tubercle, and known hingement relate the species to Schuleridea. Its dorsal margin is asymmetrically arched in a way unlike the way it is in other species of the genus.

\section{Occurrence.-}

Unit E:

NC-HY-OT-11, 3,756-3,766 feet (section $G^{\prime}-G^{\prime \prime}$, pl. 30)

Number of specimens studied.-Two.

Figured specimen.-USNM 177667.

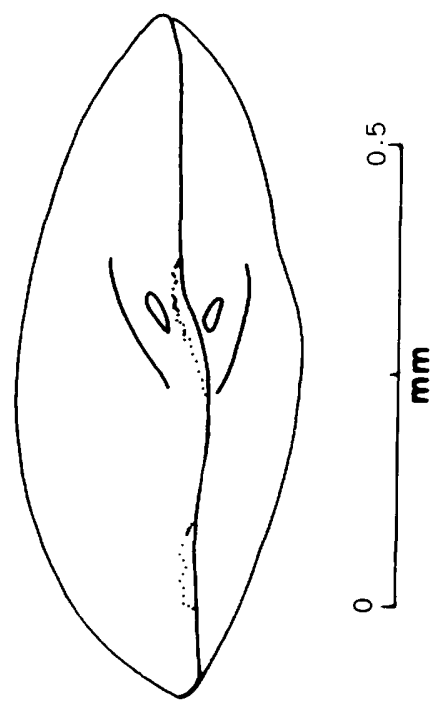

Figure 15.-Schuleridea? sp. Dorsal view of shell. Unit E. NCHY-OT-11 well, 3,756-3,766 feet.

\section{Genus PARASCHULERIDEA Swartz and Swain, 1946}

Paraschuleridea Swartz and Swain, 1946, Jour. Paleontology, v. 20, p. 370 .

Shell subtriangular to subovate; dorsum moderately to strongly convex; venter nearly straight to gently convex; anterior broadly rounded; posterior narrowly rounded, extended below; left valve larger than right, projecting strongly beyond right along dorsum and along dorsal slopes; surface smooth; right valve may have weak anterodorsal sulcus. Hinge with terminal elongate sockets in left valve and intervening noncrenulate bar; adductor muscle scar a median vertical row of four spots and one or two additional more-anterior spots.

Type species. - Paraschuleridea anumbonata Swartz and Swain, 1946.

Geologic range.-Upper Jurassic to Lower Cretaceous.

Remarks.-The relatively strong posterodorsal overlap of the right valve by the left and the smooth interterminal area of the hinge are diagnostic features of the genus.

\section{Paraschuleridea curta Swain and Brown, n. sp.}

Plate 7, figure 4

Diagnosis.-A species of Paraschuleridea more triangular in outline, with more pointed posterior end and more flattened venter than $P$. twifordensis and $P$. postumbonata.

Description.-Shell subtriangular in lateral view, highest anteromedially; dorsal margin strongly convex; ventral margin nearly straight to slightly convex; anterior margin broadly curved, slightly extended below; posterior margin subacuminate, strongly extended below. Left valve is much larger than right and extends strongly beyond it along dorsal and ventral margins. Valves not strongly convex; most convex in ventral half. General valve surfaces smooth; dorsomedially is a small depression; anterodorsally in right valve is a slight swelling.

Hinge not clearly seen but apparently consists of terminal elongate sockets and an intervening bar in left valve matched by corresponding teeth and furrow in right valve; adductor muscle scar a median vertical row of four spots and one or two more-anterior spots; marginal shell structures not seen.

Length of holotype shell $0.67 \mathrm{~mm}$, height $0.38 \mathrm{~mm}$, convexity $0.27 \mathrm{~mm}$. Type locality NC-DA-OT-13 well, Dare County, N.C.; type horizon Unit H, 5,697-5,707 feet.

Relationships.-The species is more triangular and has a flatter venter than Paraschuleridea postumbonata and Paraschuleridea twifordensis. $P$. anumbonata Swartz and Swain, 1946, the type species from the Upper Jurassic of Louisiana, is more trapezoidal in outline and is larger than the present species.

Occurrence.-

Unit $\mathrm{H}$ :

NC-DA-OT-13, 5,697-5,707 feet (section $F-F^{\prime}$, pl. 28)

NC-CUR-OT-12, 4,408-4,418 feet (section $Z^{\prime \prime}-Z^{\prime \prime \prime}$, pl. 51) 
NC-DA-OT-14, 5,009-5,019 feet (section $F-F^{\prime}$, pl. 28)

NC-DA-OT-11, 4,826-4,836 feet (section $Z^{\prime \prime}-Z^{\prime \prime \prime}$, pl. 51)

NC-HY-OT-11, 6,616-6,626 feet (section $G^{\prime}-G^{\prime \prime}$, pl. 30)

Number of specimens studied.-Six.

Figured specimen.-USNM 177673 (holotype).

Paraschuleridea postumbonata Swain and Brown, n. sp.

Plate 7, figure 3; text figure 16

Diagnosis.-Paraschuleridea having more polygonal and more elongate outline than $P$. twifordensis and stronger posterodorsal overlap of right valve by left.

Description.-Shell elongate-subelliptical in side view, highest medially; dorsal margin moderately convex; ventral margin nearly straight, slightly concave anteromedially; anterior margin curved, somewhat extended below; posterior margin narrowly curved, extended below. Valves not strongly convex; most convex medially; left valve larger than right overlapping and extending strongly beyond right dorsally and terminally, especially posterodorsally; terminal marginal zone of right valve thickened; surface smooth.

Internal shell features not clearly seen.

Length of holotype $0.62 \mathrm{~mm}$, height $0.35 \mathrm{~mm}$, width $0.33 \mathrm{~mm}$. Type locality, NC-DA-OT-12 well, Dare County, N.C.; type horizon Unit G, 6,6266,636 feet.
Relationships.-This species is more elongate and has much stronger postdorsal left-valve umbonation than $P$. twifordensis n. sp.

\section{Occurrence.-}

Unit $\mathrm{G}$ :

NC-DA-OT-12, 6,376-6,386 feet and 6,626-6,636 feet (section $Z^{\prime \prime}-Z^{\prime \prime \prime}$, pl. 51)

Number of spcimens studied.-Five.

Figured specimen.-USNM 177672.

Paraschuleridea twifordensis Swain and Brown, n. sp.

Plate 7, figure 2

Diagnosis.-A species of Paraschuleridea with subelliptical rather than polygonal outline, moderately strong posterodorsal overlap of right valve by left, and smooth shell surface.

Description.-Shell elongate-subovate, highest medially; dorsal margin moderately convex; ventral margin slightly concave; anterior margin broadly curved, slightly extended below; posterior margin more narrowly curved, extended below. Valves not strongly convex; greatest convexity median; left valve larger than right; overlapping and extending beyond right most strongly along posterodorsal slope; general surface smooth; terminal marginal zone of right valve slightly thickened.

Internal features not seen due to conditions of preservation.

Length of holotype shell $0.60 \mathrm{~mm}$, height $0.37 \mathrm{~mm}$, width $0.32 \mathrm{~mm}$. Type locality, NC-DA-OT-14 well, Dare County, N.C.; type horizon Unit H, 4,749-4,759 feet.

Relationships.-The outline of this species is less polygonal than that of Paraschuleridea anumbonata Swartz and Swain, 1946, the type species from the Upper Jurassic; $P$. postumbonata, n. sp., is more elongate and is much more strongly umbonate postdorsally, although similar in general shape.

Occurrence.-

Unit $\mathrm{H}$ :

NC-DA-OT-14, 4,749-4,759 feet (sec-

tion $F-F^{\prime}$, pl. 28)

NC-CUR-OT-12, 4,338-4,348 feet (section $J-J^{\prime}$, pl. 32)

Unit $\mathrm{G}$ :

NC-DA-OT-10, 7,305-7,315 feet (section $G^{\prime}-G^{\prime \prime}$, pl. 30 )

NC-DA-OT-9, 5,819-5,829 feet (section $Z^{\prime \prime}-Z^{\prime \prime \prime}$, pl. 51)

Number of specimens studied.-Five.

Figured specimen.-USNM 177671 (holotype). 


\section{Genus FABANELLA Martin, 1961}

Fabanella Martin, 1961, Senckenberg. Lethaea, v. 42, p. 182. Shell subquadrate; dorsum nearly straight, cardinal angles broadly obtuse; venter nearly straight to gently convex or slightly concave; anterior broadly curved; posterior typically narrower or of more or less equal curvature as anterior, rarely more broadly curved; two short anterodorsal sulci, defining small eye-tubercle lobe; anterior marginal zone compressed; general surface smooth or pitted; left valve larger than right. Hinge of right valve consists of an anterior and posterior thin tooth plate between which lies a shallow furrow; adductor muscle scar consists of an anteromedian vertical row of three or four spots and one or two additional more-anterior spots; inner lamellae narrow, vestibule present terminally, radial canals numerous, short in type species, line of concrescence slightly scalloped.

Type species._Fabanella prima Martin, 1961.

Geologic range.-Jurassic and Lower Cretaceous, Upper Cretaceous (?).

\section{Fabanella lanceolata (Swain) \\ Plate 7, figure 11; text figure 17}

Apatocythere? lanceolata Swain, 1952, U.S. Geol. Survey Prof. Paper 234-B, p. 72, pl. 9, figs. 39, 41, 42, 46.

Howe and Laurencich, 1958, Introd. study Cretaceous Ostracoda, p. 52.

The species was originally described from beds now included in Unit $\mathrm{G}$ in a well at Cape Hatteras, N.C. (NC-DA-OT-10, table 2).

Occurrence.-

Unit $\mathrm{G}$ :

NC-DA-OT-12, 5,416-5,426 feet (section $Z^{\prime \prime}-Z^{\prime \prime \prime}$, pl. 51)

NC-DA-OT-11, 4,426-4,436 feet and 4,576-4,586 (section $Z-Z^{\prime \prime \prime}$, pl. 51)

NC-HY-OT-11, 5,306-5,316 feet (section $G^{\prime}-G^{\prime \prime}$, pl. 30)

NC-DA-OT-10, 6,905-6,915 feet* (section $G^{\prime}-G^{\prime \prime}$, pl. 30 )

NC-DA-OT-13, 4,667-4,677 feet (section $F-F^{\prime}$, pl. 28)

NC-DA-OT-14, 4,629-4,639 feet (section $F-F^{\prime}$, pl. 28)

NC-CAR-OT-5, 4,612-4,622 feet (section $E-E^{\prime}$, pl. 27)

NC-CAR-OT-7, 4,020-4,030 feet (section $D-D^{\prime}$, pl. 26)

Number of specimens studied.-25+.

Figured specimens._USNM 177679, 177715.

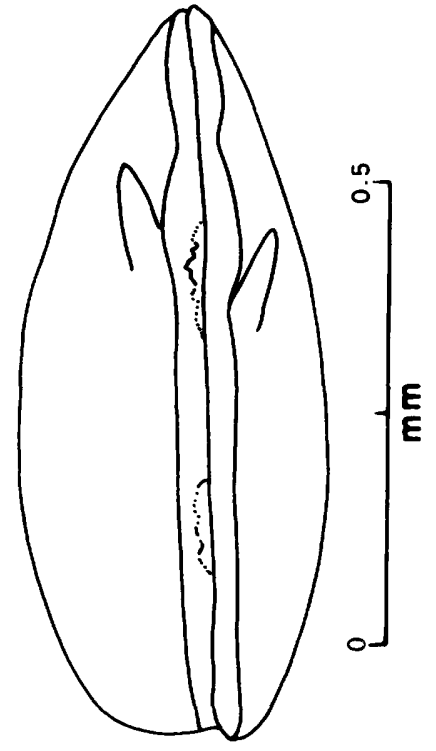

Figure 17.-Fabanella lanceolata (Swain). Dorsal view of shell. Unit G. NC-HY-OT-11 well, $5,306-5,316$ feet.

\section{Fabanella leguminoidea (Swain)}

Plate 7, figure 10; text figure 18

Apatocythere? leguminoidea Swain, 1952, U.S. Geol. Survey Prof. Paper 234-B, p. 73, pl. 9, figs. 40, 43, 45.

Howe and Laurencich, 1958, Introd. study Cretaceous Ostracoda, p. 52.

The species was originally described from beds now included in Unit $G$ in wells located in Dare County, N.C. (NC-DA-OT-9 and NC-DA-OT-10, table 2).

\section{Occurrence.-}

Unit $\mathrm{G}$ :

NC-DA-OT-14, 4,439-4,449 feet and 4,469-4,479 feet (section $F-F^{\prime}$, pl. 28) NC-DA-OT-11, 4,426-4,436 feet (section $Z^{\prime \prime}-Z^{\prime \prime \prime}$, pl. 51)

NC-HY-OT-11, 5,286-5,296 feet and 5,306-5,316 feet (section $G^{\prime}-G^{\prime \prime}$, pl. 30) NC-DA-OT-10, 6,325-6,335 feet* (section $G^{\prime}-G^{\prime \prime}$, pl. 30 )

NC-DA-OT-9, 5,539-5,549 feet* (section $Z^{\prime \prime}-Z^{\prime \prime \prime}$, pl. 51)

NC-CAR-OT-5, 4,762-4,772 feet (section $E-E^{\prime}$, pl. 27)

NC-CAR-OT-7, 4,450-4,460 feet (section $D-D^{\prime}$, pl. 26)

NC-CUR-OT-12, 3,878-3,888 feet (section $Z^{\prime \prime}-Z^{\prime \prime \prime}$, pl. 51) 
NC-HY-OT-6, 4,620-4,630 feet (section $G^{\prime}-G^{\prime \prime}$, pl. 30)

Number of specimens studied.-25+.

Figured specimens.-USNM 177680, 177631.

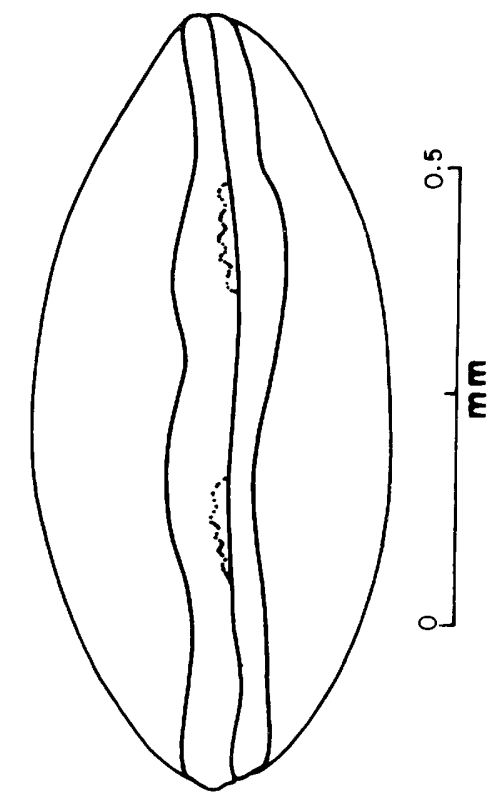

Figure 18.-Fabanella leguminoidea (Swain). Dorsal view of shell. Unit G. NC-HY-OT-11 well, 5,286-5,296 and 5,306-5,316 feet.

\section{Fabanella tumidosa (Swain)}

Plate 7, figures $5-7,9$

Apatocythere? tumidosa Swain, 1952, U.S. Geol. Survey Prof. Paper 234-B, p. 73, pl. 9, fig. 44.

Shell elongate-subovate; dorsum slightly arched; venter nearly straight; anterior broadly rounded, subtruncate above; posterior narrower, bluntly pointed, extended below; valves moderately convex; greatest convexity posteromedian; anterior marginal zone compressed; anterodorsal oblique sulcus and anteriorly adjacent oblique ridge that probably represents position of eye tubercle; surface finely and densely pitted; internal features incompletely known.

Length of figured specimen (USNM 177675, pl. 7, figs. 5a, b) $0.63 \mathrm{~mm}$, height $0.38 \mathrm{~mm}$, width 0.30 $\mathrm{mm}$.

Remarks.-The shell features of this species ally it with Fabanella Martin, 1961, rather than with Apatocythere Triebel, 1940. The species was pre- viously described (Swain, 1952) from beds now included both in Unit $\mathrm{H}$ and in Unit $\mathrm{G}$.

\section{Occurrence.-}

Unit $\mathrm{H}$ :

NC-CAR-OT-7, 4,680-4,690 feet (section $D-D^{\prime}$, pl. 26)

NC-DA-OT-10, 7,995-8,005 feet* and 8,085-8,095 feet* (section $G^{\prime}-G^{\prime \prime}$, pl. 30) NC-CAR-OT-5, 5,302-5,312 feet (section $E-E^{\prime}$, pl. 27)

NC-DA-OT-12, 7,266-7,276 feet (section $Z^{\prime \prime}-Z^{\prime \prime \prime}$, pl. 51)

NC-HY-OT-11, 6,526-6,536 feet (section $Z^{\prime}-Z^{\prime \prime}$, pl. 50)

NC-DA-OT-13, 6,007-6,017 feet (section $F-F^{\prime}$, pl. 28)

NC-DA-OT-14, 5,029-5,039 feet (section $F-F^{\prime}$, pl. 28)

NC-CUR-OT-12, 4,208-4,218 feet (section $Z^{\prime \prime}-Z^{\prime \prime \prime}$, pl. 51)

Unit G :

NC-DA-OT-12, 6,336-6,346 feet (section $Z^{\prime \prime}-Z^{\prime \prime \prime}$, pl. 51)

NC-DA-OT-10, 7,615-7,625 feet* (section $G^{\prime}-G^{\prime \prime}$, pl. 30 )

NC-HY-OT-11, 5,396-5,406 feet (section $G^{\prime}-G^{\prime \prime}$, pl. 30)

Number of specimens studied.-25+.

Figured specimens.-USNM, 177675, 177676, 177677, 177678.

\section{Fabanella sp.}

Plate 7, figure 8; text figure 19

Shell subquadrate in side view, height about three-fifths of length; dorsal margin nearly straight, also about three-fifths of shell length, with broadly obtuse, poorly defined cardinal angles; ventral margin nearly straight and subparallel to dorsum, somewhat sinuous and slightly concave anteromedially; anterior margin broadly curved, extended below, subtruncate above; posterior margin a little less broadly curved. Left valve larger than right, extending beyond right dorsally and ventrally; valves moderately convex, greatest convexity median in position. Anterior marginal area of valves compressed; anterodorsal low eye tubercle on both valves; anterodorsal oblique sulcus defines eye tubercles. General surface with large pits in middle part and finer pits in peripheral parts.

Internal shell structures could not be seen in the specimens at hand. 
Length of figured shell $0.78 \mathrm{~mm}$, height $0.48 \mathrm{~mm}$, width $0.42 \mathrm{~mm}$.

Relationships.--The species is relatively higher with respect to length than Fabanella tumidosa (Swain, 1952), is more blunt posteriorly, and has coarser median surface ornamentation than that species.

Occurrence.-

Unit $\mathrm{G}$ :

NC-HY-OT-11, 5,316-5,326 feet (sec$G^{\prime}-G^{\prime \prime}$, pl. 30)

NC-DA-OT-12, 6,376-6,386 feet (section $Z^{\prime \prime}-Z^{\prime \prime \prime}$, pl. 51)

Number of specimens studied.-Two.

Figured specimen.-USNM 177674.

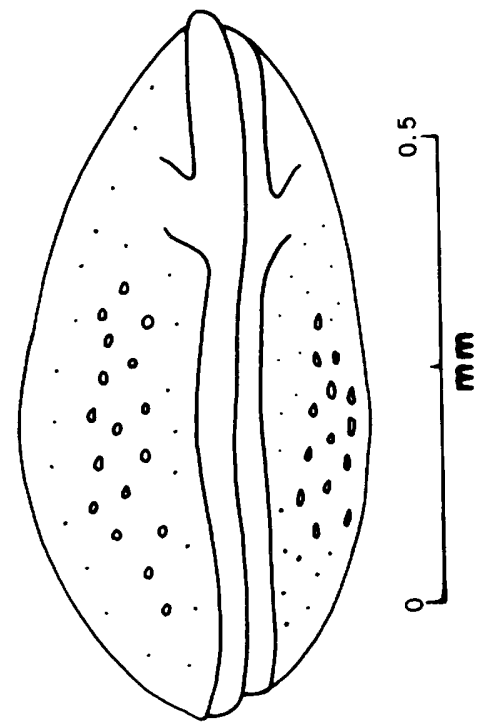

Figure 19.-Fabanella sp. Dorsal view of specimen. Unit $\mathrm{G}$. NCHY-OT-11 well, 5,316-5,326 feet.

\section{Subfamily EUCYTHERINAE Puri, 1954}

\section{Genus EUCYTHERE Brady, 1868}

Cytheropsis Sars, 1866, Oversigt af Norges Marine Ostracoder, Norske Vidensk.-Akad. Forh., p. 57 (not M'Coy, 1849).

Eucythere Brady, 1868, Linn. Soc. Trans., c. 26, p. 429.

Shell subtriangular; dorsum convex; venter straight to slightly concave; anterior broadly curved; posterior narrowly rounded, extended below; left valve larger than right; surface smooth or pitted. Hinge of left valve a groove into which fits flange of right valve; inner lamellae broad, vestibule anteriorly, line of concrescence scalloped, few radial canals; adductor muscle scar an oblique row of four spots and a more-anterior U-shaped spot.

Type species.-Cythere declivis Norman, 1865.

Geologic range.-Lower Cretaceous to Holocene.

\section{Eucythere semiglypta Swain and Brown}

Eucythere semiglypta Swain and Brown, 1964, North Carolina Dept. Conserv. and Devel. Bull. 78, p. 27, pl. 2, figs. 10a-f; pl. 3, figs. la, b; text fig. $8 \mathrm{~b}$.

The species was described from beds now included in Unit $\mathrm{F}$ in the subsurface of northeastern North Carolina.

Occurrence.-

Unit F :

NC-HAL-T-13, 125-130 feet (Nonsection well) NC-ON-OT-23, 1,103-1,113 feet (section $V-V^{\prime}$, pl. 44) MD-WOR-OT-11, 3,167-3,177 feet (section $M-M^{\prime}$, pl. 35) NJ-CM-OT-1, 3,188-3,198 feet (section $O-O^{\prime}$, pl. 37)

NC-PEN-OT-5, 1,355-1,365 feet (Nonsection well)

NC-CR-OT-30, 2,299-2,309 feet (section $D-D^{\prime}$, pl. 26)

NC-BEA-OT-13, 1,534-1,544 feet (section $X-X^{\prime}$, pl. 46)

NC-NH-OT-15, 1,461-1,471 feet (section $Z-Z^{\prime}$ pl. 49)

Number of specimens studied.- $-10+$.

\section{Family CYTHERURIDAE G. W. Müller, 1894}

\section{Genus METACYTHEROPTERON Oertli, 1957}

Metacytheropteron Oertli 1957, Rev. Inst. française Petrole et Annales Combust. Liquides, v. 12, p. 664 .

Shell elongate, almond shaped; dorsum and venter gently convex; anterior rounded; posterior pointed; left valve larger than right; surface ornamented by longitudinal ridges and reticulations; small anterodorsal eye tubercle. Hinge of right valve with elongate terminal serrate denticles and an intervening crenulate groove; inner lamellae and line of concrescence coincide; few and simple radial pore canals.

Type species.-Metacytheropteron elegans Oertli, 1957.

Geologic range.-Middle Jurassic to Upper Cretaceous. 
Metacytheropteron? bicostatum Swain and Brown, n.sp.

Plate 8, figures 1, 2; text figure 20

Diagnosis.-A Metacytheropteron-like form with fewer surface ridges than $M$. elegans, the type species, and with a doublet arrangement of longitudinal ridges.

Description.-Shell subpyriform-lanceolate in side view, highest anteromedially ; dorsal margin convex, sloping more steeply behind than in front of position of greatest height; ventral margin gently convex; anterior margin rounded, extended below; posterior margin acuminate, strongly extended medially. Valves strongly inflated, greatest convexity ventromedian. Valves subequal; narrow, double, discontinuous ridge extends from posterior margin to about three-fourths from anterior end; a second ventromedian double ridge extends from posterior margin nearly to anterior margin; ventral surface flattened due to strong expansion of venter, giving a triangular outline in end view; general surface bears some weak irregularly reticulate ridges.

Hinge consists of terminal elongate crenulate teeth in right valve and intervening crenulate furrow; and in left valve crenulate sockets and intervening bar. Other internal structures not seen in present specimens.

Length of holotype shell (USNM 177682, pl. 8, fig. 2) $0.53 \mathrm{~mm}$, height $0.30 \mathrm{~mm}$, width $0.38 \mathrm{~mm}$. Type locality, NC-CUR-OT-12 well, Currituck County, N.C.; type horizon Unit H, 4,338-4,348 feet.

Relationships.-The hingement and external form of this species relate it to Metacytheropteron Oertli, 1957. It has fewer surface ridges, and particularly has a doublet arrangement of the longitudinal ridges as compared to $M$. elegans Oertli, the type species, and other described species of the genus. Protocythere martini Bizon, 1958, from the Jurassic is similar in general shape and surface ornament but has a heavier terminal hinge structure and broader longitudinal ridges.

Occurrence.-

Unit $\mathrm{H}$ :

NC-CUR-OT-12, 4,338-4,348 feet (section $J-J^{\prime}$, pl. 32 )

Unit F :

NC-DA-OT-12, 4,696-4,706 feet (sec-

tion $Z^{\prime \prime}-Z^{\prime \prime \prime}$, pl. 51)

NC-NH-OT-15, 1,451-1,461 feet (section $Z-Z^{\prime}$, pl. 49)

Number of specimens studied.-Five.

Figured specimens.-USNM 177681 (paratype), 177682 (holotype).

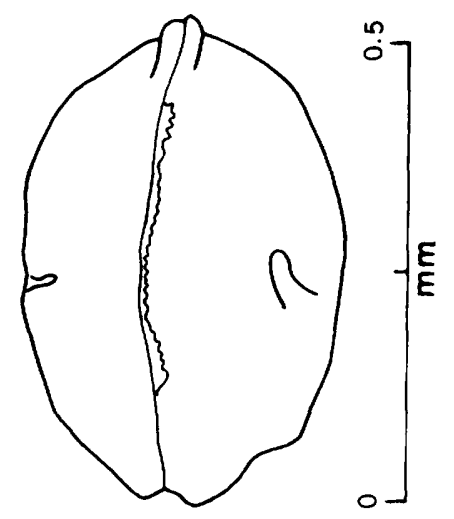

FiguRe 20. - Metacytheropteron? bicostatum Swain and Brown, n. sp. Dorsal view of holotype (USNM 177682). Unit H. NCCUR-OT-12 well, 4,338-4,348 feet.

\section{Genus OTOCYTHERE Triebel and Klingler, 1959}

Otocythere Triebel and Klingler, 1959, Geol. Jahrb., v. 76, p. 349.

Shell small, ear shaped to subovate; dorsum and venter convex; anterior broadly rounded; posterior subcaudate, extended, end compressed; left valve larger than right; valves convex; surface bears several irregular depressions and associated nodes, including muscle-area node, and may also be finely pitted. Hinge of right valve with terminal crenulate tooth plate and intervening crenulate furrow; inner lamellae narrow, little or no vestibule, radial pore canals few, but including sublateral canals.

Type species.-Otocythere callosa Triebel and Klingler, 1959.

Geologic range.-Jurassic.

Remarks.-Arculicythere Grekoff, 1963, from the Valanginian and Portlandian of Madagascar has the same general shape and large surface nodes and sulci as Otocythere but lacks the posterior caudal process of Otocythere and has an entomodont hinge, Looneyella Peck, 1951, from the Lower Cretaceous of Wyoming differs from Otocythere in having a longer and straighter dorsum.

Species of Glyptocythere Brand and Malz, 1962, from the Middle Jurassic of Europe are similar to the present species in general outline and surface ornamentation, particularly G. tuberosa Brand and Malz, 1966, and related forms (Brand and Malz, 1966). In the Glyptocythere, however, the surface contains a median furrow flanked by nodes rather than a median tubercle, and the posterior ends are not compressed into caudal processes. 


\section{Otocythere sp.}

Plate 8 , figure 3 ; text figure 21

Shell subovate in side view, highest anteromedially; dorsal margin strongly convex, sloping more steeply along anterior than along posterior part; ventral margin gently convex; anterior margin broadly curved, extended below; posterior margin narrowly curved, with ventromedian blunt, slightly upturned caudal process. Left valve larger than right, overlapping and overreaching right along dorsal and anterior margins. Valves strongly convex, greatest convexity posteromedian; posterior caudal process compressed. Anteromedially on each valve is a subvertical narrow deep sulcus; anterior and posterior to sulcus are large rounded swellings, the posterior of which is the more elongate; general surface very finely and closely pitted; irregular low ridges and nodes are superimposed on pitting.

Hinge as seen obscurely by reflected light in complete shell consists of terminal denticulate sockets in left valve and teeth in right valve. Other internal structures not clearly observed.

Length of figured shell $0.53 \mathrm{~mm}$; height $0.33 \mathrm{~mm}$, width $0.32 \mathrm{~mm}$.

Relationships.-The shape, convexity, and general surface ornamentation of this species relate it to Otocythere Triebel and Klingler, 1959, but it differs from other described species in its binodose and finely pitted surface.

Arculicythere defluxa Grekoff, 1963, from the Valanginian (Lower Cretaceous-Neocomian Stage) of Madagascar is somewhat like the present species in surface ornamentation but does not have the posterior caudal process of $O$. sp.

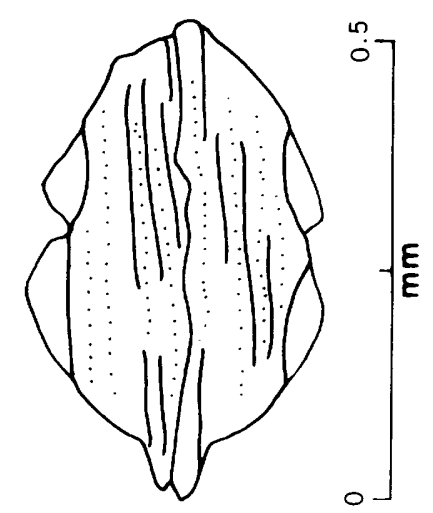

FIgURE 21.-Otocythere sp. Ventral view of shell. Unit H. NJ-CMOT-1 well, 6,038-6,048 feet.
Occurrence.-

Unit $\mathrm{H}$ :

NJ-CM-OT-1, 6,038-6,048 feet (section

$O-O^{\prime}$, pl. 37)

Number of specimens studied.-One.

Figured specimen.-USNM 177683.

\section{Genus ORTHONOTACYTHERE Alexander, 1933}

Orthonotacythere Alexander, 1933, Jour. Paleontology, v. 7, p. 199.

Shell small, subquadrate; dorsum nearly straight, cardinal angles obtuse; venter nearly straight to convex; anterior broadly curved; posterior caudate, strongly extended; left valve larger than right; valves with large nodes and smaller pits or reticulations, eye tubercle, compressed ends. Hinge of right valve with terminal elongate denticulate teeth and interterminal crenulate furrow; radial pore canals few, straight; adductor muscle scar a vertical row of four.

Type species.—Cytheridea? hannai Irsaelsky, 1929.

Geologic range.-Jurassic to Holocene.

Remarks.-Because of the similarity of Lower Cretaceous and Jurassic species assigned to Orthonotacythere in Europe with some of those referred to Hutsonia in the United States, specimens in the British Museum (Natural History) were studied.

Orthonotacythere atypica Kaye, 1965 (1965a), Lower Aptian, Atherfield, Isle of Wight, is generally similar to Hutsonia blandoidea of this paper but differs in some details of surface ornamentation. O. blanda Kaye, 1964, lower Barremian, Speeton, Yorkshire, is similar to $H$. blandoidea but has a broad sulcus rather than an anteromedian node.

Orthonotacythere catalounia Damotte and Grosdidier (1963), Lower Aptian, Isle of Wight (Kaye, 1965a), is unlike any of the North Carolina species in details of ornamentation. O. diglypta Triebel (Kaye, 1963c), Hauterivian, Speeton, Yorkshire, resembles the Albian-Cenomanian forms from North Carolina but is unlike the Hutsonia blandoidea type of this paper.

Orthonotacythere inornata Kaye, 1965 (1965a), Upper Aptian, Chale Bay, Isle of Wight, O. minutissima Kaye, 1965 (1965b), Gault, Wrotham, Kent, and $O$. sp. B of Kaye and Barker (1965), Upper Aptian, Sutterby, Lincolnshire, are not Orthonotacythere but resemble Monoceratina bifurcata Puri from the Tertiary. O. inver'sa Cornuel, 1848, Middle Hauterivian, Nettleton, Lincolnshire, and $O$. inversa 
tuberculata Kaye and Barker, 1965, Upper Aptian, Sutterby, Lincolnshire, somewhat resemble Hutsonia rugata Swain, 1946, of the Upper Jurassic of Louisiana. O. fordensis Kaye, 1965 (1965b), Gault, Wrotham, Kent, is unisulcate and has a rounded rather than tuberculose postdorsal lobe; it is unlike any of the Hutsonias of this paper, but some specimens have the posterior end drawn out and upturned as in Hutsonia males.

Orthonotacythere spinifera Kaye, 1965 (1965b), Gault, Wrotham, Kent, is nearly nonsulcate and resembles Parexophthalmocythere. O. sp. A of Kaye (1965a), Lower Aptian, Atherfield, Isle of Wight, also resembles that genus.

Cytheropterina Mandelstam, 1956 (in Mandelstam and others, 1956) was placed in Orthonotacythere by Howe (in Moore, 1961), but J. W. Neale does not believe the two genera are synonymous.

\section{Orthonotacythere delicatula Swain and Brown}

Orthonotacythere delicatula Swain and Brown, 1964, North Carolina Dept. Conserv. and Devel. Bull. 78, p. 40, pl. 3 , figs. 15a-c.

The species was described from beds now included in Unit $F$ in the subscurace of northeastern North Carolina.

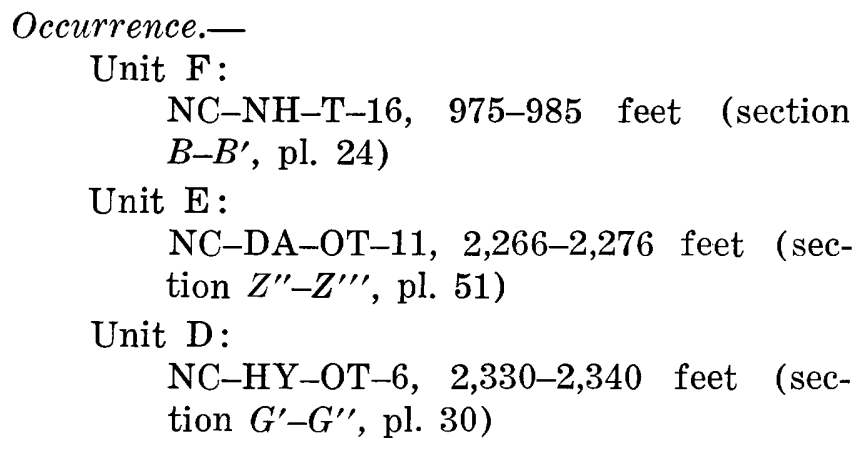

Number of specimens studied.-Three.

\section{Genus EOCYTHEROPTERON Alexander, 1933}

Cytheropteron (Eocytheropteron) Alexander, 1933, Jour. Paleontology, v. 7, p. 195.

Eocytheropteron Alexander. Sharapova, 1937, Geol. Oil Inst., Trans. ser. A., no. 106, p. 81 (but used in connection with $E$. saturnoformis Sharapova, a nomen nudum).

Eocytheropteron Alexander. Calahan, 1939, Shreveport Geol. Soc., Guidebook 14th Ann. Field Trip, p. 51.

Shell small, subovate to almond shaped; in side view dorsum strongly convex; venter less convex; anterior broadly curved; posterior with short caudal extension; valves strongly convex; left valve larger than right, overreaching dorsally. Hinge of left valve with terminal elongate crenulate sockets and interterminal weakly crenulate ridge; inner lamellae narrow, radial canals few; venter strongly swollen and angulated in end view, surface smooth, pitted, reticulate or with ventral longitudinal ridges.

Type species.-Cytheropteron bilobatum Alexander, 1929.

Geologic range.-Upper Jurassic( ?) to Eocene(?).

\section{Eocytheropteron trinitiensis (Vanderpool)}

Plate 8, figures 4,5

Cytheridea trinitiensis Vanderpool, 1928, Jour. Paleontology, v. 2 , p. 106 , pl. 14, figs. 3-6.

Cytheropteron (Eocytheropteron) trinitiensis (Vanderpool). Vanderpool, 1933, Jour. Paleontology, v. 7, p. 410, pl. 49 , figs. 16-19.

Swain, 1952, U.S. Geol. Survey Prof. Paper 234-B, p. 86 , pl. 9 , figs. 9,10 .

Eocytheropteron trinitiensis (as “trinitensis") (Vanderpool). Calahan, 1939, Shreveport Geol. Soc. Guidebook, 14th Ann. Field Trip, p. 51, pl. 8, figs. 7a-d.

Howe and Laurencich, 1958, Introd. study Cretaceous Ostracoda, p. 327.

Swain and Brown, 1964, North Carolina Dept. Conserv. and Devel. Bull. 78, p. 39, pl. 5, figs. 4a-e, 5a-c; text fig. 11d.

\section{Occurrence.-}

Unit $\mathrm{G}$ :

NC-HY-OT-6, 4,330-4,340 feet (section $G^{\prime}-G^{\prime \prime}$, pl. 30)

NC-HY-OT-11, 5,036-5,046 feet (section $G^{\prime}-G^{\prime \prime}$, pl. 30)

NC-DA-OT-12, 5,386-5,396 feet (section $Z^{\prime \prime}-Z^{\prime \prime \prime}$, pl. 51)

NC-DA-OT-10, 6,145-6,155 feet* and 6,315-6,325 feet* (section $Z^{\prime \prime}-Z^{\prime \prime \prime}$, pl. 51)

NC-DA-OT-11, 4,526-4,536 feet (section $Z^{\prime \prime}-Z^{\prime \prime \prime}$, pl. 51)

NC-DA-OT-13, 4,947-4,957 feet (section $F-F^{\prime}$, pl. 28)

NC-DA-OT-14, 4,619-4,629 feet (section $F-F^{\prime}$, pl. 28 )

NC-CAR-OT-5, 4,382-4,392 feet (section $E-E^{\prime}$, pl. 27)

NC-CAR-OT-6, 3,770-3,780 feet (section $X-X^{\prime}$, pl. 46) 
NC-CAR-OT-7, 4,420-4,430 feet (sec-

tion $D-D^{\prime}$, pl. 26)

NC-CAR-OT-9, 3,688-3,698 feet (sec-

tion $X-X^{\prime}$, pl. 46)

NC-PAM-OT-3, 3,373-3,383 feet (sec-

tion $E-E^{\prime}$, pl. 27)

NC-PAM-OT-9, 3,498-3,508 feet (sec-

tion $E-E^{\prime}$, pl. 27)

Number of specimens studied.-25+.

Figured specimens.-USNM 177684, 177685.

\section{Eocytheropteron tumidum Alexander}

Cytheropteron tumidum Alexander, 1929, Univ. Texas Bull. 2907, p. 103, pl. 10, figs. 16, 17.

Cytheropteron (Eocytheropteron) tumidum Alexander, 1933, Jour. Paleontology, v. 7, p. 199, pl. 27, figs. 13a, b.

Eocytheropteron tumidum (Alexander). Calahan; 1939, Shreveport Geol. Soc. Guidebook, 14th. Ann. Field Trip, p. 49 , pl. 7 , fig. 7 .

Howe and Laurencich, 1958, Introd. study Cretaceous Ostracoda, p. 328.

Swain and Brown, 1964, North Carolina Dept. Conserv. and Devel. Bull. 78, p. 39, pl. 3, fig. 13.

The species has been recorded from the Goodland and Kiamichi Formations of Texas and Louisiana; from the lower part of the Atkinson Formation of Florida, and from beds now included in Unit $F$ in northeastern North Carolina.

Occurrence.-

Unit $\mathrm{F}$ :

NC-NH-OT-15, 1,451-1,461 feet (section $Z-Z^{\prime}$, pl. 49)

Number of specimens studied.-Three.

\section{Eocytheropteron tumoides (Swain)}

Cytheropteron (Eocytheropteron) tumoides Swain, 1952, U.S. Geol. Survey Prof. Paper 234-B, p. 86, pl. 9, figs. $7,8$.

Eocytheropteron tumoides (Swain). Howe and Laurencich, 1958, Introd. study Cretaceous Ostracoda, p. 328.

The species was previously described from beds now included in Unit $\mathrm{G}$ in a well at Cape Hatteras, N.C. (NC-DA-OT-10, table 2) .

Occurrence.-

Unit $\mathrm{G}$ :

NC-HY-OT-11, 5,016-5,026 feet (section $G^{\prime}-G^{\prime \prime}$, pl. 30)

NC-DA-OT-10, 6,315-6,325 and 6,735-

6,745 feet* (section $G^{\prime}-G^{\prime \prime}$, pl. 30)

NC-CAR-OT-5, 4,672-4,682 feet (section $E-E^{\prime}$, pl. 27)
NC-CAR-OT-7, 4,380-4,390 feet (sec-

tion $D-D^{\prime}$, pl. 26)

NC-PAM-OT-9, 3,468-3,478 feet (sec-

tion $E-E^{\prime}$, pl. 27)

NC-DA-OT-11, 4,476-4,486 feet (sec-

tion $Z^{\prime \prime}-Z^{\prime \prime \prime}$, pl. 51)

NC-DA-OT-12, 5,546-5,556 feet (sec-

tion $Z^{\prime \prime}-Z^{\prime \prime \prime}$, pl. 51)

NC-DA-OT-13, 4,527-4,537 feet (sec-

tion $F-F^{\prime}$, pl. 28 )

NC-DA-OT-14, 4,639-4,649 feet (section $F-F^{\prime}$, pl. 28)

Number of specimens studied.-25+.

\section{Eocytheropteron venoides Swain and Brown}

Eocytheropteron venoides Swain and Brown, 1964, North Carolina Dept. Conserv. and Devel. Bull. 78, p. 38, pl. 3 , figs. $12 \alpha-f$, text fig. $11 \alpha$.

This species was previously described from beds now included in Unit $\mathrm{F}$ in a well in Pitt County, N.C.

Occurrence.-

Unit $\mathbf{F}$ :

NC-NH-T-16, 975-985 feet (section

$B-B^{\prime}$, pl. 24)

NC-HAL-T-13, 125-130 feet (Nonsection well)

NC-NH-OT-15, 1,371-1,381 feet (section $Z-Z^{\prime}$, pl. 49)

Unit D:

NC-HY-OT-6, 2,330-2,340 feet (section $G^{\prime}-G^{\prime \prime}$, pl. 30)

Number of specimens studied.-25+.

\section{Genus EUCYTHERURA G. W. Müller, 1894}

Eucytherura G. W. Müller, 1894, Fauna u. Flora des Golfes von Neapel, v. 21, p. 305.

Shell small, subquadrate; dorsal and ventral margins nearly straight and convergent posteriorly; anterior broadly rounded; posterior narrower, caudate in dorsal half; valve surface reticulate or nodose; shell inflated in ventral half, dimorphic; anterodorsal eye tubercle. Hinge as in Cytherura; adductor muscle scar a median vertical row of four spots and an additional anterodorsal spot; line of concrescence and inner margin typically coincide; radial canals few and straight.

Type species.-Cythere complexa Brady, 1867.

Geologic range.-Cretaceous to Holocene. 


\section{Eucytherura? sp.}

Plate 8 , figure 6 ; text figure 22

Shell subquadrate in side view, highest medially; dorsal margin nearly straight, slightly sinuous, with somewhat obtuse cardinal angles; ventral margin slightly convex; anterior margin broadly curved, slightly extended below, subtruncate above; posterior margin more narrowly curved, extended above. Valves subequal. Valves strongly convex ventroposteriorly; venter flattened and slightly overhangs ventral margin. A shallow sulcus lies anterior to middle in dorsal half; valve surface more convex behind and ventral to sulcus; anterior to and ventral to sulcus, narrow low ridges connected by scattered crossbars lie concentrically to margins; posterior to sulcus the surface is weakly reticulate with the longitudinal ridges of the reticulum somewhat more prominent than the other elements; surface finely pitted between ridges. Narrow terminal flattened rims occur on each valve.

Internal shell features could not be seen clearly in specimens at hand.

Length of figured shell $0.53 \mathrm{~mm}$, height $0.28 \mathrm{~mm}$, width $0.30 \mathrm{~mm}$.

Relationships.-In general outline, swollen posterior half, and surface ornamentation, this species is similar to Eucytherura Müller and Gomphocythere Sars, 1924, but the latter has a somewhat stronger median sulcus. The present form is only questionably referred to this genus. It is less strongly alate than typical forms of the genus and differs in its weakly reticulate ornamentation from other described species.

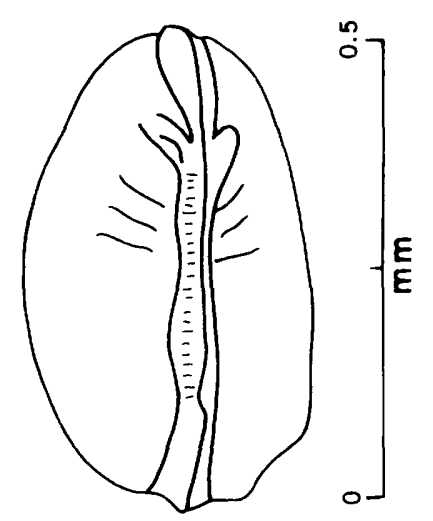

FIGURE 22.-Eucythemura? sp. Dorsal view of shell. Unit F. NCHY - OT - 11 well, $4,456-4,466$ feet.
Occurrence.-

Unit F :

NC-HY-OT-11, 4,456-4,466 feet (sec-

tion $G^{\prime}-G^{\prime \prime}$, pl. 30)

Number of specimens studied.-Three.

Figured specimen.-USNM 177686.

\section{Family PROGONOCYTHERIDAE Howe, 1961}

\section{Subfamily PROGONOCYTHERINAE}

Sylvester-Bradley, 1948

\section{Genus JUVENIX Kuznetsova, 1957}

Juvenix Kuznetsova, in Mandelstam and others, 1957, AllUnion Palaeont. Soc., Annual, Moscow, v. 16, p. 184.

Shell medium sized, elongate-subquadrate; dorsum and venter nearly straight, subparallel or convergent posteriorly; anterior rounded, may have anterior marginal flange; posterior narrower or with short caudal process; valves convex; left valve larger than right; median sulcus; ventral ridge or swelling; surface reticulate or pitted. Hinge of left valve has terminal crenulate sockets and interterminal crenulate bar; radial canals few.

Type species.—Juvenix pseudocuspidatus Kuznetsova, 1957.

Geologic range.-Lower Cretaceous, Neocomian.

\section{Juvenix sp.}

Plate 8 , figure 7 ; text figure 23

Shell elongate-subquadrate in side view, highest about one-fifth from anterior end; dorsal margin basically straight but somewhat sinuous, concave medially; ventral margin nearly straight, slightly concave medially, converging with dorsum in a posterior direction; anterior margin broadly curved, bearing about five short projections along ventral two-thirds, slightly truncate above; posterior margin narrow, bluntly pointed, strongly extended submedially. Valves subequal, moderately convex, greatest convexity posteromedian in position. Anteromiddorsal surface of shell depressed as a broad shallow sulcus, anterior to which lies an oblique eyetubercle ridge; posterodorsal shell surface swollen; anterior marginal zone compressed and bears a narrow rim; general surface coarsely punctate in a roughly reticulate pattern.

Hinge of left valve consists of terminal elongate denticulate sockets and an interterminal crenulate hinge surface. Inner lamellae of moderate width 
anteriorly; line of concrescence and inner margin coincide.

Length of figured left valve $0.77 \mathrm{~mm}$, height 0.38 $\mathrm{mm}$, width of valve $0.22 \mathrm{~mm}$.

Relationships.-The general shape, broad anterodorsal sulcus, and rugose surface of this species are similar to features of Orthonotacythere problematica Kaye and Barker (1966) from the Lower Barremian of England. That species, however, has a tuberculate surface and ventral alae that project beyond the valve margin. The shape, surface ornamentation, and hingement relate this species to Juvenix Kuznetsova, but the surface ornamentation is different than that of described species.

\section{Occurrence.-}

Unit $\mathrm{H}$ :

NC-CAR-OT-5, 5,252-5,262 feet (section $E-E^{\prime}$, pl. 27)

Number of specimens studied.-Two.

Figured specimen.-USNM 177687.

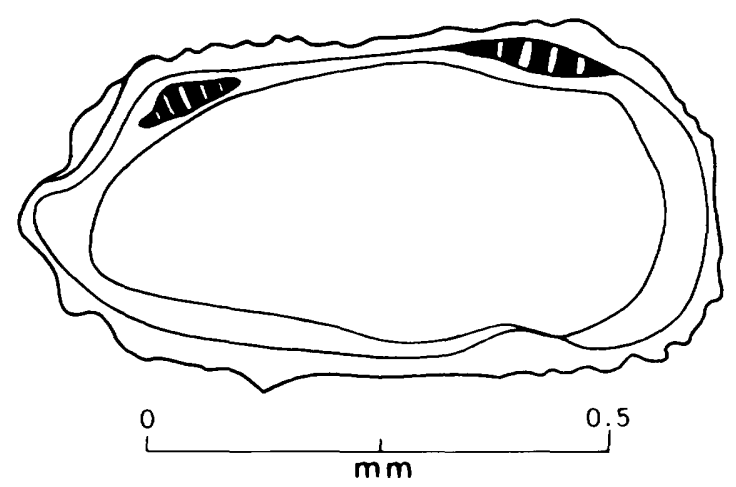

Figure 23.-Juvenix sp. Interior of left valve. Unit H. NC-CAR-OT-5 well, 5,252-5,262 feet.

\section{Genus CENTROCYTHERE Mertens, 1956}

Centrocythere Mertens, 1956, Geol. Jahrb., v. 72, p. 203.

Shell small, ovate; dorsum straight, obtuse cardinal angles; venter convex; anterior broadly curved, extended below; posterior narrowly curved to subcaudate, extended above; left valve slightly larger than right; valves moderately convex; anterodorsal small eye tubercle present; surface with concentrically arranged ridges or rows of nodes that intersect dorsum nearly at right angles. Hinge (entomodont) of right valve has anterior rounded tooth, postjacent small socket, interterminal groove which is crenulate part of the way back, and posterior crenulated tooth; inner lamellae moderately broad, little or no vestibule; radial canals few; adductor muscle scar a vertical row of four spots.
Type species.-Centrocythere denticulata Mertens, 1956.

Geologic range.-Lower Cretaceous.

\section{Centrocythere annulopapillata Swain and Brown}

Centrocythere annulopapillata Swain and Brown, 1964, North Carolina Dept. Conserv. and Devel. Bull. 78, p. 41 , pl. 3 , figs. $16 a-c$.

The species was described from the lower member of the Atkinson Formation of Florida and Georgia.

Occurrence.-

Unit F :

NC-DA-OT-12, 5,166-5,176 feet (section $Z^{\prime \prime}-Z^{\prime \prime \prime}$, pl. 51)

Unit E:

NC-HY-OT-11, 3,766-3,776 feet (section $G^{\prime}-G^{\prime \prime}$, pl. 30)

NC-DA-OT-9, 3,569-3,579 feet (section $Z^{\prime \prime}-Z^{\prime \prime \prime}$, pl. 51)

Number of specimens studied.-Four.

\section{Subfamily PROTOCYTHERINAE Liubimova, 1955}

\section{Genus HUTSONIA Swain, 1946}

Hutsonia Swain, 1946, Jour. Paleontology, v. 20, p. 123.

Shell small, subpyriform; dorsum nearly straight to sinuous, anterior cardinal angle less obtuse than posterior; anterior broadly rounded to truncate; posterior narrow; extended above; left valve larger than right valve; bisulcate, pitted, reticulate, or rugose; venter with slight longitudinal swelling. Hinge holomerodont; adductor muscle scar a submedian vertical row of four spots and an additional more-anterior crescentic spot; inner lamellae narrow; vestibule narrow or absent; radial canals few. Marine and brackish waters.

Type species.-Hutsonia vulgaris Swain, 1946. Upper Jurassic, Louisiana subsurface.

Geologic range.-Upper Jurassic to Lower Cretaceous.

\section{Hutsonia blandoidea Swain and Brown, n. sp.}

Plate 8, figures 24-26; plate 9, figures 2-5; text figure 24

Diagnosis.-A subquadrate, bisulcate Hutsonia with roughly reticulate surface ornamentation and posteroventral submarginal ridge; less deeply sulcate than $H$. rugosa of Upper Jurassic. 

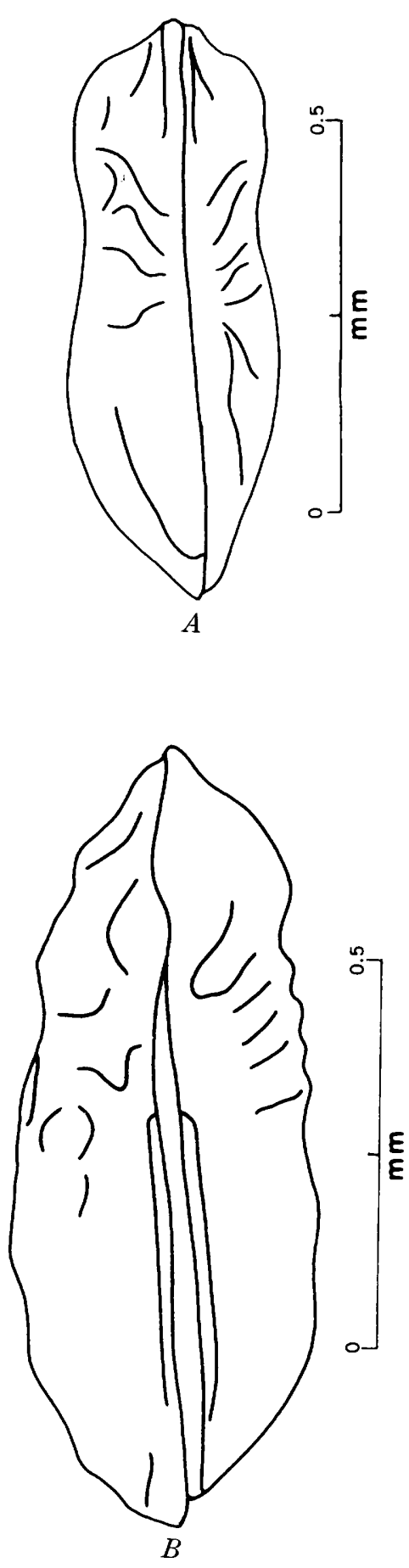

Figure 24.-Hutsonia blandoidea Swain and Brown, n. sp. $A$, Dorsal view of male and female shells. Unit G. NC-DA-OT-12 well, 5,686-5,696 feet; $B$, dorsal view of female shell. Unit $\mathrm{H}$. NC-DA-OT-11 well, 4,776-4,786 feet.
Description.-Shell subquadrate in side view, highest about one-fifth from anterior end; dorsal margin nearly straight, anterior cardinal angle less obtuse than posterior; ventral margin nearly straight, gently convex, converging slightly toward dorsum in posterior direction; anterior margin broadly curved, somewhat extended below and truncate above; posterior margin narrower, strongly extended to subcaudate above, truncate below. Valves not strongly convex, greatest convexity median to anteromedian; shell constricted in front of middle because of sulcation; posterior end compressed. Valves subequal, the left slightly the larger. A prominent, slightly anteromedian sulcus extends from dorsum to venterad of midheight, anterior to sulcus is a lobe, rounded dorsally, not extending to dorsal margin, and which in turn is defined anteriorly by a relatively short somewhat oblique anterodorsal sulcus; posteroventral surface bears a low narrow ridge parallel to but at some distance from margin; general surface incompletely reticulate.

Internal features mainly not seen because of conditions of preservation; hingement as seen in reflected light under water appears to consist of terminal crenulate elongate teeth in right valve and sockets in left valve.

Length of holotype shell (USNM 177703, pl. 9, fig. 3) $0.65 \mathrm{~mm}$, height $0.38 \mathrm{~mm}$, width $0.27 \mathrm{~mm}$. Type locality, NC-CAR-OT-7 well, Carteret County, N.C. ; type horizon Unit H, 4,680-4,690 feet.

Relationships.-In external form and general character of surface ornamentation, this species is similar to Hutsonia rugosa Swain, 1946, from the Upper Jurassic Schuler Formation of Louisiana. It is less deeply sulcate and the surface reticulating ridges are less elevated than in $H$. rugosa.

Orthonotacythere blanda Kaye, 1963 (1963c), of the Barremian of England is similar to this form but has a broad sulcus and no anteromedian node.

\section{Occurrence.-}

Unit $\mathrm{H}$ :

NC-DA-OT-13, 5,697-5,707 feet and $5,687-5,697$ feet (section $F-F^{\prime}$, pl. 28 ) NC-DA-OT-11, 4,776-4,786 feet (section $Z^{\prime \prime}-Z^{\prime \prime \prime}$, pl. 51)

NC-CAR-OT-5, 5,122-5,132 feet (section $E-E^{\prime}$, pl. 27)

NC-CAR-OT-7, 4,680-4,690 feet (section $D-D^{\prime}$, pl. 26)

NC-DA-OT-12, 8,106-8,116 feet (section $Z^{\prime \prime}-Z^{\prime \prime \prime}$, pl. 51)

NC-HY-OT-11, 6,626-6,636 feet (section $G^{\prime}-G^{\prime \prime}$, pl. 30 ) 
NC-CUR-OT-12, 4,208-4,218 feet (section $Z^{\prime \prime}-Z^{\prime \prime \prime}$, pl. 51)

NC-DA-OT-14, 4,729-4,739 feet (section $F-F^{\prime}$, pl. 28)

Unit $\mathrm{G}$ :

NC-DA-OT-11, 4,606-4,616 feet (section $Z^{\prime \prime}-Z^{\prime \prime \prime}$, pl. 51)

NC-DA-OT-12, 5,686-5,696 feet (section $Z^{\prime \prime}-Z^{\prime \prime \prime}$, pl. 51)

Number of specimens studied.-15+.

Figured specimens.-USNM 177701 (paratype), 177702 (paratype), 177703 (holotype), 177704, 177705 (paratype), 177629, 177630.

\section{Hutsonia collinsensis collinsensis Swain and Brown, n. sp., n. subsp.}

Plate 8 , figures $8-14,22,23$; figure 25

Diagnosis.-A subquadrate Hutsonia with two narrow anterodorsal sulci, anteromedian and dorsomedian lobes, posteromedian dorsal and ventral low swellings, posteromedian longitudinal depression, and reticulate surface.

Description.-Shell subquadrate in lateral view, highest about one-fourth from anterior end; dorsal margin nearly straight, slightly sinuous, anterior cardinal angle more obtuse than posterior cardinal angle; ventral margin straightened medially, converging posteriorly toward dorsum; anterior margin broadly rounded, somewhat extended below; posterior margin much more narrowly curved, prominently extended above. Valves moderately convex, constricted anteromedially in dorsal view owing to sulcation. Left valve larger than, and overlaps, right along free margins. A narrow anteromedian sulcus begins at dorsal margin and extends about two-thirds distance to ventral margin; in holotype and some other specimens ventral part of sulcus is shallower than dorsal part; a second sulcus rises near anterodorsal cardinal angle and extends curving slightly, about to midheight; another short subvertical sulcus lies ventral to, but is slightly offset from, anterodorsal sulcus; these sulci define a low but distinct anterodorsal lobe and a second low ventromedian lobe which is separated from preceding lobe by a shallow longitudinal furrow; a broad longitudinal depression extends posteriorly from median sulcus to about one-fourth from posterior end where it opens into general shell surface; both dorsal and ventral to depression and bordering margins are broad longitudinal elevations; median de- pression has a narrow median longitudinal ridge in well-preserved mature specimens; terminal parts of shell weakly reticulate and pitted; median part of shell has widely spaced small pits. Surface ventral to lobes and to sulci in left valve has a longitudinal low ridge; in right valve ridge is only weakly developed and has small nodes at either end.

Male shells are somewhat lower with respect to length than are female shells.

Hinge of right valve as seen by transmitted light consists of terminal elongate crenulate teeth and intervening crenulate bar; inner lamellae rather narrow; radial canals few and widely spaced, bulbous in the middle; inner margin smooth, vestibule small or absent. Other internal structures not clearly seen.

Length of holotype shell (USNM 177689, pl. 8, fig. 9) $0.55 \mathrm{~mm}$, height $0.31 \mathrm{~mm}$, width $0.23 \mathrm{~mm}$. Type locality, NC-CUR-OT-12 well, Currituck County, N.C.; type horizon Unit H, 4,318-4,328 feet.

Relationships.-The lesser elongation, pattern of surface lobes, and sulci of this subspecies separate it from $H$. collinsensis attenuata new subsp.

\section{Occurrence.-}

Unit $\mathrm{H}$ :

NC - CUR - OT - 12, 4,318-4,328 feet, 4,328-4,338 feet, and 4,338-4,348 feet (section $J-J^{\prime}$, pl. 32)

NC-DA-OT-13, 5,687-5,697 feet (section $F-F^{\prime}$, pl. 28)

NJ-CM-OT-1, 4,578-4,588 feet (section $O-O^{\prime}$, pl. 37)

NC-DA-OT-11, 4,706-4,716 feet (section $Z^{\prime \prime}-Z^{\prime \prime \prime}$, pl. 51)

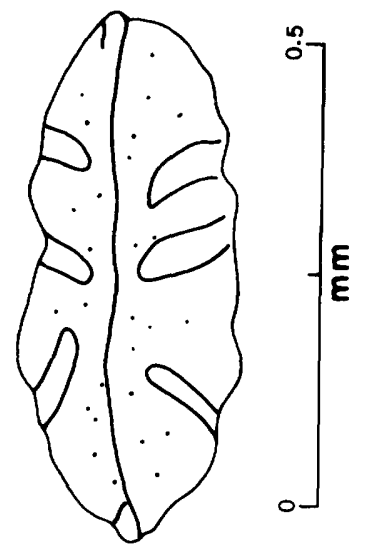

Figure 25.-Hutsonia collinsensis collinsensis Swain and Brown, n. sp., n. subsp. Dorsal view of paratype shell. Unit G. NC-DA-OT-11 well, 4,5964,606 feet. 
MD-WOR-OT-11, 5,122-5,132 feet (section $M-M^{\prime}$, pl. 35)

NC-DA-OT-12, 7,746-7,756 feet (section $Z^{\prime \prime}-Z^{\prime \prime \prime}$, pl. 51)

NC-CAR-OT-7, 4,770-4,780 feet (section $D-D^{\prime}$, pl. 26)

NC-CAR-OT-5, 5,342-5,352 feet (section $E-E^{\prime}$, pl. 27)

NC-DA-OT-14, 5,009-5,019 feet (secUnit $\mathrm{G}$ : tion $F-F^{\prime}$, pl. 28 )

NC-DA-OT-12, 6,626-6,636 feet (section $Z^{\prime \prime}-Z^{\prime \prime \prime}$, pl. 51)

NC-DA-OT-11, 4,596-4,606 feet and 4,606-4,616 feet (section $Z^{\prime \prime}-Z^{\prime \prime \prime}$, pl. 51)

Number of specimens studied.-25+.

Figured specimens. - USNM 177688 (paratype), 177689 (holotype), 177690 (paratype), 177691 (paratype), 177692 (paratype), 177693 (paratype), 177694 (paratype), 177695, 177696.

\section{Hutsonia collinsensis attenuata Swain and Brown, n. subsp.}

Plate 8, figure 15; text figure 26

Diagnosis.-More elongate and with weaker median longitudinal furrow and weaker posteromedian swellings than $H$. collinsensis collinsensis.

Description.- Shell features similar to those of $H$. collinsensis collinsensis, but shell is more elongate and does not have well-defined posterolongitudinal median depression and marginally adjacent elevated areas as in that subspecies.

Internal structures obscured by conditions of preservation in specimens available for study.

Length of holotype shell (USNM 177697, pl. 8, fig. 15) $0.63 \mathrm{~mm}$, height $0.33 \mathrm{~mm}$, width $0.22 \mathrm{~mm}$. Type locality, NC-DA-OT-13 well, Dare County, N.C.; type horizon Unit H, 5,697-5,707 feet.

\section{Occurrence.-}

Unit $\mathrm{H}$ :

NC-DA-OT-13, 5,697-5,707 feet (section $F-F^{\prime}$, pl. 28)

NC-DA-OT-14, 4,737-4,747 feet (section $F-F^{\prime}$, pl. 28)

Unit G:

NC-HY-OT-11, 5,686-5,698 feet (section $G^{\prime}-G^{\prime \prime}$, pl. 30)

NC-DA-OT-12, 6,696-6,706 feet (section $Z^{\prime \prime}-Z^{\prime \prime \prime}$, pl. 51)

NC-DA-OT-11, 4,606-4,616 feet (section $Z^{\prime \prime}-Z^{\prime \prime \prime}$, pl. 51)
Number of specimens studied.-Five.

Figured specimen.-USNM 177697 (holotype).

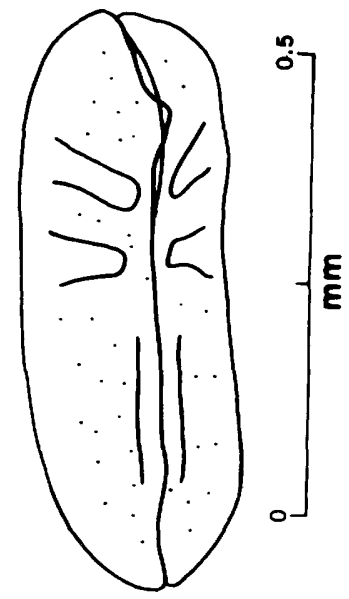

FIgURE 26.-Hutsonia collinsensis attenuata Swain and Brown, n. subsp. Dorsal view of holotype (USNM 177697). Unit H. NC-DA-OT-13 well, 5,697-5,707 feet.

\section{Hutsonia collinsensis micropunctata Swain and Brown,} n. subsp.

Plate 8 , figures 16,17 ; text figure 27

Diagnosis.-Hutsonia collinsensis in which surface is weakly and finely pitted, and posterior dorsal and ventral swellings are low.

Description.-Shell similar to that of $H$. collinsensis collinsensis in general shape and sulcation, but posterior dorsal and ventral longitudinal elevations are much weaker and surface reticulation is absent or nearly so. Minor surface ornamentation consists of scattered small pits.

Internal characteristics of shells not clearly seen as the shells are filled with calcite; inner lamellae are narrow and radial canals are few.

Length of holotype shell (USNM 177699, pl. 8, fig. 17) $0.52 \mathrm{~mm}$, height $0.20 \mathrm{~mm}$, width $0.28 \mathrm{~mm}$. Type locality NC-DA-OT-12 well, Dare County, N.C.; type horizon Unit H, 7,106-7,116 feet.

\section{Occurrence.-}

Unit $\mathrm{H}$ :

NC-CUR-OT-12, 4,328-4,338 feet (section $J-J^{\prime}$, pl. 32)

NC-DA-OT-12, 7,106-7,116 feet (section $Z^{\prime \prime}-Z^{\prime \prime \prime}$, pl. 51) 
Unit $\mathrm{G}$ :

NC-DA-OT-11, 4,576-4,586 feet (section $Z^{\prime \prime}-Z^{\prime \prime \prime}$, pl. 51)

NC-DA-OT-12, 6,576-6,586 feet and 6,626-6,636 feet (section $Z^{\prime \prime}-Z^{\prime \prime \prime}$, pl. 51)

Number of specimens studied.-25+.

Figured specimens.-USNM 177698(paratype), 177699 (holotype).

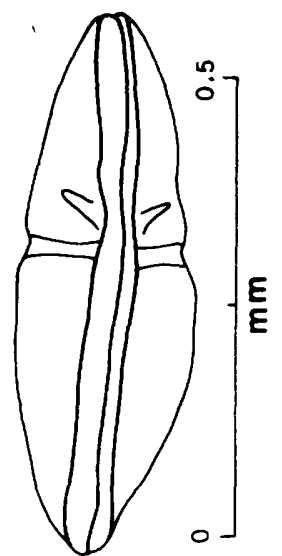

Figure 27.-Hutsonia collinsensis micropunctata Swain and Brown, n. subsp. Dorsal view of shell. Unit G. NC-DAOT-12 well, 6,626-6,636 feet.

\section{Hutsonia collinsensis subsp.}

Plate 8, figure 18

Shell subpyriform in side view, highest one-fourth from anterior end; dorsal margin slightly convex and undulating, cardinal angles broadly obtuse; ventral margin gently convex, converging posteriorly toward dorsum; anterior margin broadly curved, extended medially, truncate above, posterior margin narrowly rounded, extended above. A narrow vertical, sinuous, slightly anteromedian, sulcus rises near dorsal margin and extends to near midheight; ventral to this sulcus is a short narrow, curving groove; anterodorsal lobe narrows dorsally; general surface finely, weakly and sparsely pitted.

Inner lamellae rather narrow, radial canals simple and widely spaced; hinge consists of terminal elongate crenulate teeth in right valve and sockets in left valve; interterminal area not clearly seen; adductor muscle scar consists of an anteromedian vertical row of three or four spots situated ventrad of anteromedian lobe.

Length of figured shell $0.56 \mathrm{~mm}$, height $0.30 \mathrm{~mm}$, width $0.21 \mathrm{~mm}$.
Relationships.-This subspecies differs from Hutsonia collinsensis sensu stricto in its somewhat weaker sulcation, smoother surface, and more sinuous dorsum.

\section{Occurrence.-}

Unit $\mathrm{H}$ :

NC-CUR-OT-12, 4,318-4,328 feet (section $J_{-} J^{\prime}$, pl. 32)

NC-DA-OT-12, 7,106-7,116 feet (section $Z^{\prime \prime}-Z^{\prime \prime \prime}$, pl. 51)

Unit $\mathrm{G}$ :

NC-DA-OT-11, 4,606-4,616 feet (section $Z^{\prime \prime}-Z^{\prime \prime \prime}$, pl. 51)

Number of specimens studied.-Three.

Figured specimen.-USNM 177700.

\section{Hutsonia? cf. H.? microrugosa Swain}

Plate 8, figure 19

Hutsonia? micromgosa Swain, 1952, U.S. Geol. Survey Prof. Paper 234-B, p. 88, pl. 9, fig. 14.

The species was originally described from beds now included in Unit $\mathrm{G}$ in a well at Cape Hatteras, N.C. (NC-DA-OT-10, table 2).

Occurrence.-

Unit $\mathrm{H}$ :

NC-DA-OT-11, 4,776-4,786 feet (section $Z^{\prime \prime}-Z^{\prime \prime \prime}$, pl. 51)

Unit $\mathrm{G}$ :

NC-DA-OT-12, 5,606-5,616 feet and $5,756-5,766$ feet (section $Z^{\prime \prime}-Z^{\prime \prime \prime}$, pl. 51) NC-DA-OT-10, 6,235-6,245 feet* (section $G^{\prime}-G^{\prime \prime}$, pl. 30)

Number of specimens studied.-Three.

Figured specimen.-USNM 177707.

\section{Hutsonia sp.}

Plate 9, figure 1

A specimen having the shell features illustrated could not be placed in a described species; the anteromedian lobe is weaker and the adjoining sulci are broader and shorter than in $H$. collinsensis $\mathrm{n}$. sp., although the reticulate surfaces of the two forms are similar.

Length of figured specimen $0.63 \mathrm{~mm}$, height 0.32 $\mathrm{mm}$, width $0.30 \mathrm{~mm}$.

Occurrence.-

Unit $\mathrm{H}$ :

NC-CAR-OT-7, 4,680-4,690 feet (section $D-D^{\prime}, \mathrm{pl} .26$ ) 
Number of specimens studied.-One.

Figured specimen.-USNM 177706.

\section{Hutsonia? sp., immature}

Plate 8, figures 20, 21

Hutsonia sp. Swain, 1949, Am. Assoc. Petroleum Geologists Bull., v. 33, p. 1236, pl. 3, figs. 21, 22.

The two forms illustrated are from the Schuler Formation, Upper Jurassic, of Louisiana. They are from a depth of 5,045-5,063 feet in the MorganSmith No. 2 well, Bossier Parish, La. They are introduced here for comparison with the other Hutsonia of the collection, but may represent a different genus.

Figured specimens.-USNM 177708, 177709.

\section{Genus PROTOCYTHERE Triebel, 1938}

Protocythere Triebel, 1938, Senckenbergiana, v. 20, p. 180.

Shell subpyriform-subquadrate; donsum sinuous, anterior cardinal angle elevated; venter convex; anterior broadly rounded; posterior narrowly curved to bluntly pointed; left valve larger than right, especially in cardinal areas; valves strongly convex; dorsal, median, and ventral longitudinal ridges with intervening furrows; general surface smooth or weakly pitted or pustulose. Hinge of left valve with terminal elongate denticulate sockets, and interterminal crenulate bar; inner lamellae broad, no vestibule, radial pore canals numerous anteriorly, few posteriorly, with bulbous expansions; adductor muscle scar a median vertical row of four spots and a more-anterior crescentic spot.

Type species.—Cytherina triplicata Roemer, 1840.

Geologic range.-Jurassic to Cretaceous.

\section{Protocythere aff. P. aptensis Oertli}

Plate 9, figures 7,8

Shell elongate, subquadrate to sublanceolate, highest near anterior end; dorsal margin slightly sinuous to nearly straight, elevated at anterior cardinal angle; venter also slightly sinuous to nearly straight, converging moderately toward posterior with respect to dorsum; anterior margin broadly rounded, slightly extended below; posterior margin narrowly rounded, extended medially; valves compressed; left valve slightly larger than right; valves weakly arrowhead shaped in edge view owing to posteroven- tral low alate expansion. Anterior, dorsal, and posterior margins with smooth broad marginal rim. Anteromedian broad swelling passes posteriorly into a less broad longitudinal ridge; ventromedially is another broad longitudinal ridge that terminates in a low ala posteroventrally.

Internal shell features not observed.

Length of a figured specimen (USNM 177713, pl. 9, fig. 8) $0.83 \mathrm{~mm}$, height $0.45 \mathrm{~mm}$, width $0.37 \mathrm{~mm}$.

Remarks.-This form resembles Protocythere aptensis Oertli (1958, p. 1511, pl. 6, figs. 144-157) in general outline and broad smooth surface rims and ridges. That species has the cardinal areas of the left valve more upturned than the present form and has the ventral longitudinal ridge connected anteriorly with the median ridge.

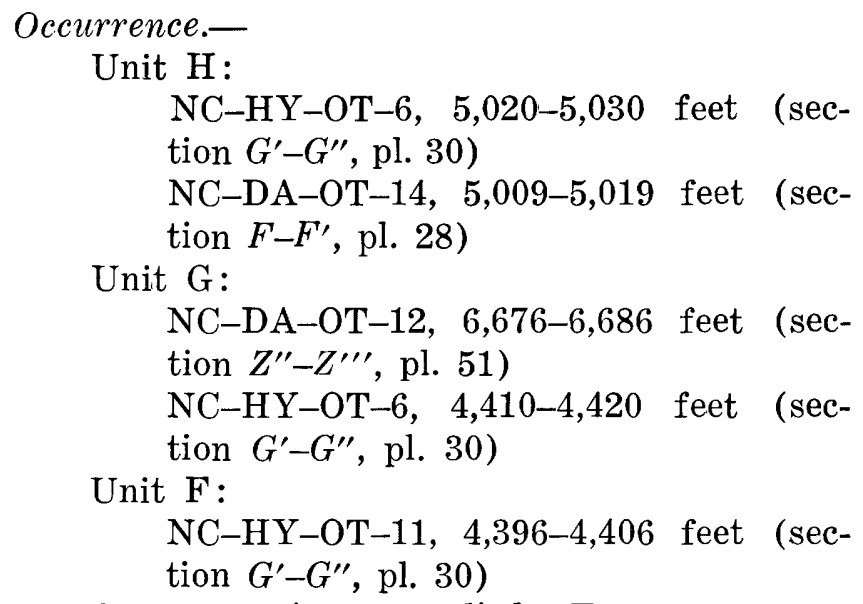

Number of specimens studied.-Four.

Figured specimens.-USNM 177712, 177713.

\section{Protocythere sp. aff, P. inornata Kaye}

Plate 9, figure 6

Shell elongate-subquadrate, highest near anterior end; dorsum nearly straight, slightly sinuous, cardinal angles obtuse; venter nearly straight converging posteriorly with dorsum; anterior broadly curved, extended below; posterior narrow, extended medially to dorsomedially; valves compressed; dorsal and terminal margins with rather broad elevated rim that at anterior end has subsidiary furrow parallel to margin; venter bears low alaform ridge that terminates near posterior end, and slightly overhangs ventral margin posteriorly; anteromedian surface has a broad low elongate swelling posterior to which is a narrower longitudinal dorsomedian ridge; general surface smooth.

Internal shell structures not observed because of conditions of preservation in present material. 
Length of figured specimen (USNM 177711, pl. 9, fig. 6) $0.70 \mathrm{~mm}$, height $0.35 \mathrm{~mm}$, width $0.35 \mathrm{~mm}$.

Remarks.-Although the preservation of the present specimens is poor, they show some affinities with the Neocomian species from England (Kaye, 1964; Kaye and Barker, 1966), but differ rather markedly in the anterior termination of the ventral rib compared with those assigned to Kaye's species.

Occurrence.-

\section{Unit $\mathrm{G}$ :}

NC-DA-OT-12, 6,676-6,686 feet (section $Z^{\prime \prime}-Z^{\prime \prime \prime}$, pl. 51)

Number of specimens studied.-Two.

Figured specimen.-USNM 177711.

\section{Protocythere? sp. 1}

Plate 9, figure 9 ; text figure 28

Shell subquadrate to elongate-subpyriform in side view, highest about one-fifth from anterior end; dorsal margin nearly straight with notches at each cardinal area; ventral margin nearly straight and subparallel to dorsum; anterior margin broadly rounded; posterior margin narrower, extended medially and truncate above. Convexity of valves low; valves subequal. Anterior end with broad marginal rim that is ornamented by two parallel rows of, in part crescentic, pits, and that terminates dorsally at cardinal angle; dorsal margin with a broad low rim extending beyond valve margin and that has a row of pits on it; posterior end of valve compressed and has a marginal ridge; dorsomedially and submedially are two longitudinal slightly oblique furrows in each of which are numerous small pits, and tiny narrow twisting ridges; general surface has scattered shallow pits.

Hinge of left valve consists of anterior deep socket, postjacent high notched tooth, interterminal weakly crenulate bar and posterior deep socket; inner lamellae rather narrow with concentric striations, radial canals few and widely spaced; adductor muscle scar an anteromedian subvertical row of several spots and one? more-anterior spot.

Length of figured shell $0.93 \mathrm{~mm}$, height $0.47 \mathrm{~mm}$, width $0.45 \mathrm{~mm}$.

Relationships.-The shape, longitudinal ridges, cardinal angle projections, and general internal features ally this species with Protocythere. This species has somewhat less notched hinge teeth and sockets and is more elongate than most in the genus; in details of ornamentation in the longitudinal furrows, it seems to differ from described forms.
Occurrence.-

Unit F :

NC-HY-OT-11, 4,426-4,436 feet (section $G^{\prime}-G^{\prime \prime}$, pl. 30)

Number of specimens studied.-Two.

Figured specimen.-USNM 177710.

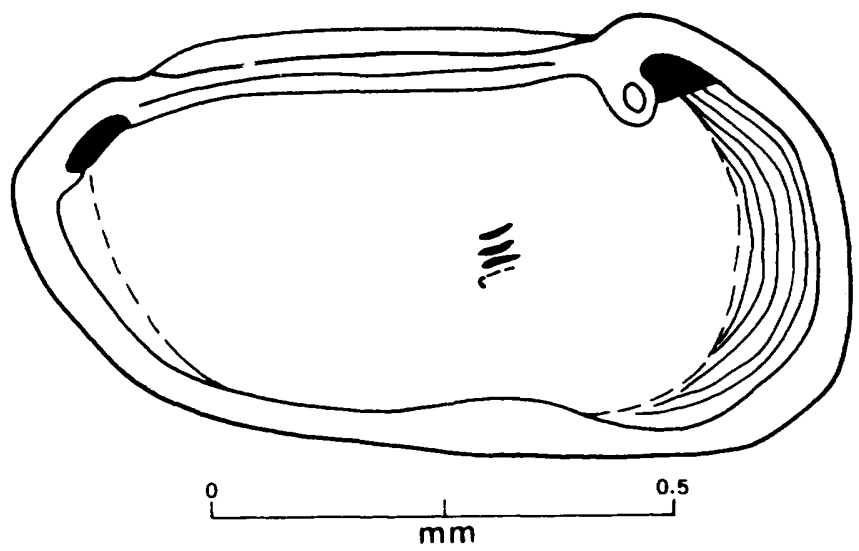

Figure 28.-Protocythere? sp. 1. Interior of left valve. Unit F. NC-HY-OT-11 well, 4,426-4,436 feet.

\section{Protocythere? sp. 2}

A specimen was obtained that is similar to Veenia paratriplicata (Swain, 1952) in general outline and features of surface ornamentation. As compared to that species, however, this form is more elongate, and the dorsal, ventral, and median longitudinal ridges are narrower. The elongate form is more suggestive of Protocythere than of Veenia Butler and Jones, 1957, and it is questionably referred to that genus.

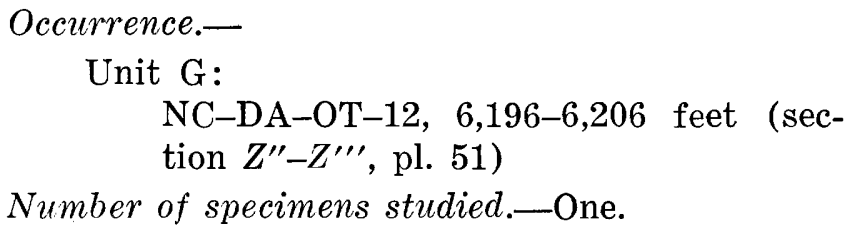

\section{Genus KLIEANA Martin 1940}

Klieana, Martin, 1940, Senckenbergiana, v. 22, p. 322.

Shell small, subovate to subquadrate; dorsum and venter gently convex to nearly straight; ends rounded, the anterior broader; left valve larger than right; valves ventrally inflated in females, less inflated in males; marginal rim present at least anteriorly; ventral submarginal ridge or ala; surface smooth, pitted, reticulate, or with longitudinal ridges. Hinge of right valve with terminal crenu- 
lated teeth, intervening bar and accommodation groove; inner lamellae narrow, no vestibule, radial pore canals few, may be paired; adductor muscle scar a vertical row of four spots.

Type species.-Klieana alata Martin, 1940.

Geologic range.-Jurassic and Cretaceous.

\section{Klieana? sp.}

Plate 9, figure 11; text figure 29

Shell subquadrate in side view, highest anteromedially; dorsal margin nearly straight, slightly concave medially; ventral margin nearly straight, converging slightly with dorsum toward posterior; anterior broadly curved, somewhat extended and with about four small spines below; posterior margin much narrower, extended medially, truncate above; curvature of posteroventral margin interrupted by overhanging alate surface of valves. Anterior, posterior, and dorsal margins with narrow compressed borders; anterodorsally is a short

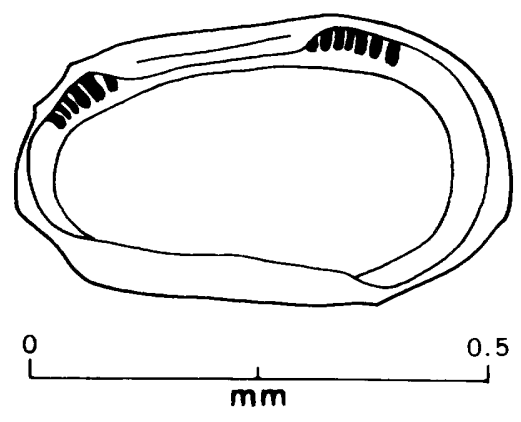

FiguRE 29.-Klieana? sp. Interior of left valve. Unit G. NJ-CMOT-1 well, 4,328-4,338 feet.

oblique eye-ridge and subjacent small sulcus; ventral part of valves strongly inflated, overhanging margin; venter bears a broad low alaform ridge that has abrupt posterior termination; anteromedian surface with slightly oblique narrow sulcus; narrow, discontinuous longitudinal ridges ornament surfaces of valves, especially in dorsal and posterior parts.

Hinge of left valve consists of terminal elongate denticulate sockets and an interterminal slightly crenulate bar, dorsal to which is a shallow accommodation groove; inner lamellae of moderate width; vestibule absent or nearly so; radial canals and muscle scar not seen.
Length of figured shell $0.58 \mathrm{~mm}$, height $0.32 \mathrm{~mm}$, width $0.20 \mathrm{~mm}$.

Relationships.-The general shape and hingement of this form show a relationship to Klieana Martin, 1940. The broad ventral swelling of the valve surface as well as details of surface ornamentation separate this species from previously described forms.

\section{Occurrence.-}

Unit $\mathrm{G}$ :

NC-DA-OT-12, 6,576-6,586 feet (section $Z^{\prime \prime}-Z^{\prime \prime \prime}$, pl. 51)

NJ-CM-OT-1, 4,328-4,338 feet (section $O-O^{\prime}$, pl. 37)

Number of specimens studied.-Two.

Figured specimen.-USNM 177714.

\section{Family TRACHYLEBERIDIDAE Sylvester-Bradley, 1948}

\section{Genus CYTHEREIS Jones, 1849}

Cythereis Jones, 1849, Mon. Cretaceous Entomostraca, Palaeontographical Soc., London, p. 14.

Shell subquadrate, medium sized; dorsum nearly straight but anterior cardinal area typically elevated, cardinal angles obtuse; venter straight; anterior broadly curved; posterior much narrower strongly extended below, truncate above; left valve larger than right; anterior and posterior spinose, elevated marginal rims; ventral longitudinal ridge; dorsal row of spines or spinose ridge; anterodorsal eye tubercle; anteromedian node, longitudinal ridge posterior to node; general surface reticulate, pitted, or pustulose. Hinge paramphidont; adductor muscle scar an anteromedian vertical row of four spots and a more-anterior $V$-shaped spot; inner lamellae fairly broad, vestibule narrow or absent, radial canals numerous.

Type species.-Cytherina ornatissima Reuss, 1846.

Geologic range.-Cretaceous.

\section{Cythereis praeornata Swain and Brown}

Cythere ornata Vanderpool, 1928, Jour. Paleontology, v. 2, p. 106, pl. 14, figs. 7, 8.

not Cythere ornata (Bosquet). Bosquet, 1854, Mon. Crustacés fossiles du terrain crétacé du Duché de Limbourg, Comm. description et carte géol. Néerlande, Mém., v. 2 , p. 102 , pl. 9 , figs. $8 \mathrm{a}-$ d.

Cythereis praeornata Swain and Brown, new name, 1964, North Carolina Dept. Conserv. and Devel. Bull. 78, p. 35 , pl. 5, figs. $6 \mathrm{a}-\mathrm{c}$; text fig. $10 \mathrm{~b}$.

The species was recorded previously from the 
DeQueen Limestone (Trinitian) of Arkansas and the Glen Rose Formation (Trinitian) of Texas.

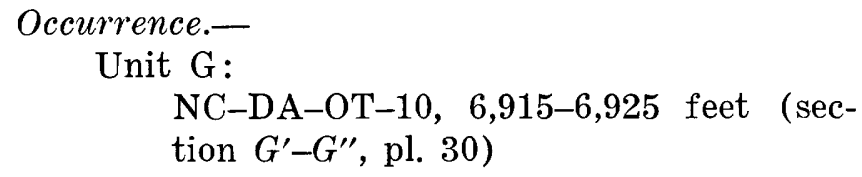

Number of specimens studied.-One.

\section{Cythereis cf. C. dentonensis Alexander}

Plate 9, figures 17-19; text figure 30

Cythereis dentonensis Alexander, 1929, Univ. Texas Bull. 2907 , p. 94 , pl. 8 , figs. $10,11$.

Shell elongate-subquadrate; dorsum basically straight except for projecting nodes and elevated anterocardinal angle; venter also basically straight, but slightly concave due to terminoventral projections of margin; anterior broadly curved with marginal frill that typically is irregular in width owing to breakage; posterior narrow, strongly extended and bearing four to five stout spines below, truncate to slightly concave above. Left valve slightly larger than right; valves compressed. Anterior and posterior ends with narrow submarginal rims, that of anterior nodose; posteromidventral surface bears sharp alate expansion; prominent anterodorsal rounded eye tubercle extends beyond valve margin; dorsal margin with three nodose extensions beyond valve margin; at posterior end of hinge is a fourth large node; anteromedian rounded node prominent and is surrounded by numerous smaller nodes; general valve surface pitted and weakly reticulate.

Internal shell characters not seen in specimens at hand.

Length of figured shell (USNM 177628, pl. 9, fig. 19) $0.62 \mathrm{~mm}$, height $0.37 \mathrm{~mm}$, width $0.32 \mathrm{~mm}$.

Remarks.-The species is similar in shape and general surface ornamentation to Cythereis dentonensis Alexander, 1929, from the Washitan of Texas but has a slightly different pattern of surface nodes and a more frill-like anterior margin.

Occurrence.-

Unit F :

NJ-CM-OT-1, 3,418-3,428 feet (section $O-O^{\prime}$, pl. 37)

NC-CAR-OT-5, 3,768-3,778 feet (section $E-E^{\prime}$, pl. 27)

NC-CAR-OT-6, 3,010-3,020 feet (section $X-X^{\prime}$, pl. 46)

NC-CAR-O'T-7, 3,380-3,390 feet (section $D-D^{\prime}$, pl. 26)
NC-PAM-OT-9, 2,908-2,918 feet (section $E-E^{\prime}$, pl. 27)

NC-DA-OT-13, 3,347-3,357 feet (section $F-F^{\prime}$, pl. 28)

NC-CUR-OT-12, 2,828-2,838 feet (section $J-J^{\prime}$, pl. 32)

Number of specimens studied.-10+.

Figured specimens.-USNM 177627, 177628.

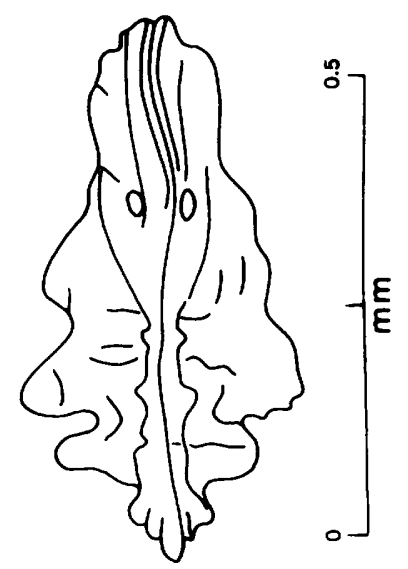

FIGURE 30.-Cythereis cf. C. dentonensis Alexander. Dorsal view of shell. Unit F. NJ-CM-OT-1 well, 3,418-3,428 feet.

Cythereis sp. aff. C. lamplughi Kaye

Plate 9, figure 10

Poorly preserved specimens, showing similar shell features to Kaye's (1963b, p. $236 ; 1965 a$, p. 46) species from the Aptian and lower Albian of England were obtained in the present collection. The outline is subquadrate-subpyriform, shell compressed; anterior dorsal and ventral margins with rim; eye tubercle present; posterior end compressed separated from rest of shell by a subvertical ridge; anteromedian elongate swelling and posteromedian narrower longitudinal ridge or swelling; general surface smooth.

Length of an unfigured specimen $0.75 \mathrm{~mm}$, height $0.36 \mathrm{~mm}$, width $0.37 \mathrm{~mm}$.

Remarks.-The specimens at hand are too poorly preserved to permit definite identification.

Occurrence.-

Unit $\mathrm{G}$ :

NC-DA-OT-12, 6,276-6,286 feet (section $Z^{\prime \prime}-Z^{\prime \prime \prime}$, pl. 51) 
Number of specimens studied.-Four.

Figured specimen.-USNM 177621.

\section{Cythereis sp.}

Plate 9, figure 16

Shell elongate-subquadrate in lateral view, highest about one-fifth from anterior end; dorsal margin somewhat sinuous, although fundamentally straight, concave anteromedially, with broadly obtuse cardinal angles; ventral margin also sinuous, but basically straight, concave anteromedially; anterior margin broadly curved, slightly escalloped, extended below, subtruncate above; posterior margin narrower, bearing four blunt spines below. Valves not strongly convex. Anterior margin bears a narrow flattened border having several cross ridges; within border is a narrow high ridge that terminates dorsally in an enlarged area representing eye tubercle, and which continues along venter a short distance; posterior margin has a narrow irregular rim; anteromedian surface with broad low swelling terminated posteriorly by a furrow, but merging gradually with surface toward anterior; midventrally is a broad, low submarginal ridge that terminates abruptly about one-fifth of shell length from posterior end; general surface with a reticulate pattern of narrow ridges between which surface is finely and densely pitted. Median posterior surface forms a broad low ridge.

Length of figured shell $0.97 \mathrm{~mm}$, height $0.48 \mathrm{~mm}$, width $0.48 \mathrm{~mm}$.

Remarks.-In general shape and surface ornamentation this species resembles Cythereis cristata Kaye, 1964, from the Aptian of England, but that species lacks the coarse surface reticulation of the present form and is more quadrate in lateral outline.

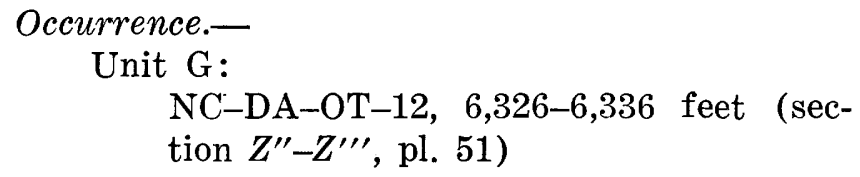

Number of specimens studied.-One.

Figured specimen.-USNM 177626.

\section{Genus ISOCYTHEREIS Triebel, 1940}

Isocythereis Triebel, 1940, Senckenbergiana, v. 22, p. 208. Caudites Mandelstam (part), 1961, in Orlov and others, Basic Paleontogy, Arthropoda Volume, State Sci. Tech. Pub. House, Moscow, p. 391.
Shell elongate-subquadrate; dorsum sinuous but fundamentally straight; venter concave medially; anterior broadly curved; posterior bluntly pointed; anterior and posterior marginal areas of shell compressed; anterior, and perhaps other margins, with elevated marginal rim; anterodorsal eye tubercle; anteromedian node; narrow subvertical ridge extends downward from posterior cardinal angle; ventral longitudinal ridge. Hinge hemiamphidont; adductor muscle divided into as many as nine spots with a more-anterior $V$-shaped spot and additional more-ventral spots; zone of concrescence broad, radial pore canals long; no vestibule.

Type species. - Isocythereis fissicostis Triebel, 1940.

Geologic range.-Lower Cretaceous.

\section{Isocythereis? sp.}

Plate 9, figure 15; text figure 31

Shell elongate-subquadrate in side view, highest about one-fifth from anterior end; dorsal margin nearly straight, merging gradually with anterior margin but having broadly obtuse cardinal angle posteriorly; ventral margin nearly straight, slightly concave posteromedially; anterior margin broadly rounded, slightly extended below, fringed with small nodes; posterior margin narrow, bluntly angulated and strongly extended medially, concave above. Valves compressed, subequal, the left slightly larger. Free margins with narrow elevated rim; a low rim also parallels dorsum but is not continuous with free-marginal rim; posterodorsal cardinal area with subtriangular projection; anteromedian surface with low oblique swelling; posterior ven-

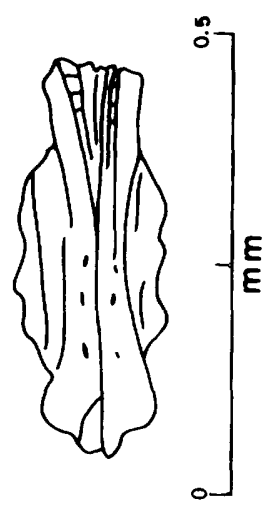

Figure 31.-Isocythereis? sp. Dorsal view of shell. Unit G. NJCM-OT-1 well, 3,748-3,758 feet. 
tral submarginal surface with low oblique alaform ridge; posterior end compressed. General surface smooth.

Internal characteristics of shell could not be seen because of conditions of preservation-shell filled with matrix.

Length of figured shell $0.45 \mathrm{~mm}$, height $0.22 \mathrm{~mm}$, width $0.13 \mathrm{~mm}$.

Relationships.-In shape, compressed valves, and pattern of surface ornamentation, this species resembles Isocythereis fissicostis Triebel, 1940, from the Albian of Germany. That species has a broader marginal frill, more denticulated margins, weak surface reticulation, and a narrow median longitudinal ridge not possessed by the present form.

Occurrence.-

Unit G :

NJ-CM-OT-1, 3,748-3,758 feet (section $O-O^{\prime}$, pl. 37)

Number of specimens studied.-Two.

Figured specimen.-USNM 177625.

\section{Cytheracea, Family Uncertain}

\section{Genus MANDELSTAMIA Liubimova, 1955}

Mandelstamia Liubimova, 1955, All-Union Petroleum Scientific Research Geol. Exploration Inst. (VNIGRI) Trans., n. s., v. 84, p. 62.

Shell small, elongate-subquadrate; dorsum and venter subparallel; dorsum straight, cardinal angles obtuse; venter slightly concave; ends rounded; left valve larger than right; surface pitted, reticulate, or tuberculate; weakly sulcate anteromedially. Hinge of right valve with terminal small teeth and an interterminal groove; adductor muscle scar an anteromedian vertical row of four spots and two moreanterior spots; inner lamellae broad anteriorly where vestibule occurs; radial pore canals straight, few in number. Marine?.

Type species.-Mandelstamia facilis Liubimova, 1955.

Geologic range.-Upper Jurassic to Lower Cretaceous.

\section{Mandelstamia? sp.}

Plate 9, figure 14

Shell small, subovate, highest one-fourth from anterior end; hinge margin nearly straight, about three-fourths of shell length; venter convex, converging posteriorly with dorsum; anterior broadly curved, extended below, subtruncate above; posterior narrowly curved, extended above. Valves subequal, the left slightly larger. Valves moderately convex; surface with low scattered pustulose swellings; anterodorsally one of the swellings seems to represent an anterior lobe as it is bounded on either side by a narrow sulcuslike furrow, presenting the appearance of a waist in dorsal view (Neale and Kilenyi, 1961).

Inner lamellae narrow; radial canals short and rather numerous, but not clearly seen; hingement and muscle scar not visible.

Length of figured specimen $0.58 \mathrm{~mm}$, height 0.33 $\mathrm{mm}$, width $0.22 \mathrm{~mm}$.

Remarks.-The shape and observable internal features of this form relate it to Mandelstamia Liubimova, 1955 (Liubimova, 1955; 1956 (in Mandelstam and others, 1956)), but further identification cannot be made on the specimens at hand.

Occurrence.-

Unit $\mathrm{G}$ :

NC-DA-OT-12, 6,536-6,546 feet (section $Z^{\prime \prime}-Z^{\prime \prime \prime}$, pl. 51)

Number of specimens studied.-Two.

F'igured specimen.-USNM 177624.

\section{Genus TAXODIELLA Kuznetsova, 1957}

Taxodiella Kuznetsova in Mandelstam and others, 1957, AllUnion Paleont. Soc., Ann., Moscow, v. 16, p. 174.

Shell small, elongate-subquadrate; dorsum and venter subparallel, straight to slightly convex; anterior rounded; posterior subcaudate, extended medially or dorsomedially; ends compressed; surface with longitudinal ridges and reticulations; ventral surface may be expanded, subalate. Hinge with long crenulate groove (and terminal crenulate teeth?) in right valve;(?) inner lamellae narrow, with small vestibule terminally;(?) adductor muscle scar an anteromedian vertical row of four spots, the upper one paired and an additional two moreanterior spots.

Type species.-Taxodiella fiscellaformis Kuznetsova, 1957.

Geologic range.-Lower Cretaceous.

\section{Taxodiella sp.}

Plate 9, figures 12, 13; text figure 32

Shell subelliptical-subtrapezoidal in side view, highest medially; dorsal margin nearly straight, 
with broadly obtuse cardinal angles; ventral margin gently convex, somewhat sinuous owing to alate expansion of venter; anterior margin narrowly curved, extended below; posterior margin subacuminate, strongly extended medially. Valves subequal, strongly convex, greatest convexity ventral in position. Ventral part of shell alate; the alae surmounted by narrow ridges that begin near anteroventral margin and continue posteriorly to about one-fourth from posterior end where alae terminate; posterior end somewhat compressed; terminal margins with narrow low rims; general surface with narrow reticulating ridges and with tiny closely spaced pits between ridges.

Hinge of right valve consists of terminal elongate crenuate tooth ridges and an interterminal crenulate groove; inner lamellae narrow; line of concrescence and inner margin slightly separated terminally; radial pore canals few and widely spaced; adductor muscle scar consists of a vertical anteromedian curved row of four spots, the upper one paired, and two additional spots anterior to the adductor group.

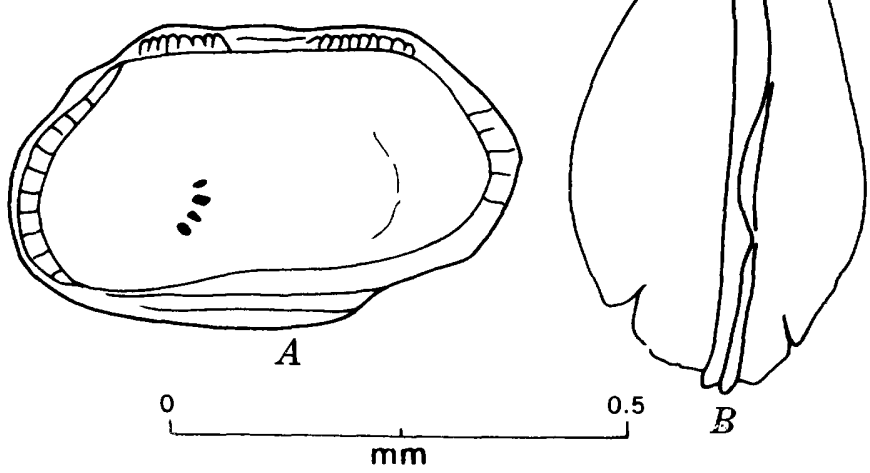

Figure 32.-Taxodiella sp. $A$, Interior of right valve; $B$, dorsal view of shell. Unit $\mathrm{H}$. NC-CUR-OT-12 well, 4,2984,318 feet.

Length of right valve (USNM 177623, pl. 9, fig. 13) $0.62 \mathrm{~mm}$, height $0.33 \mathrm{~mm}$, width of valve 0.27 $\mathrm{mm}$.

Relationships.-This species is similar to Taxodiella fiscellaformis Kuznetsova, 1957, from the Barremian Stage of Azerbaidjan in shape, hingement, and general surface ornamentation but is somewhat more alate ventrally and has fine pits in addition to surface longitudinal narrow ridges.
Occurrence.-

Unit $\mathrm{H}$ :

NC-CUR-OT-12, 4,298-4,318 feet (sec-

tion $J_{-} J^{\prime}$, pl. 32)

Number of specimens studied.-Two.

Figured specimens.-USNM 177622, 177623.

\section{REFERENCES}

Abushik, A. F., and others, 1958, New genera and species of Ostracoda, in Microfauna USSR, v. 9: All-Union Petroleum Scientific Research Geol. Exploration Inst. Leningrad (VNIGRI) Trans., n.s. no. 115, p. 232-287, 6 pls.

Alexander, C. I., 1929, Ostracoda of the Cretaceous of north Texas: Univ. Texas Bull. 2907, 137 p., 10 pls.

- 1933, Shell structure of the ostracode genus Cytheropteron and fossil species from the Cretaceous of Texas: Jour. Paleontology, v. 7, p. 181-214, pls. 25-27.

Anderson, F. W., 1939, Wealden and Purbeck Ostracoda: Annals and Mag. Nat. History, ser. 11, v. 3, p. 291-310, pls. $12,13$.

Anderson, J. L., and others, 1948, Cretaceous and Tertiary subsurface geology: Maryland Dept. Geology, Mines, and Water Resources, Bull. 2, 441 p., 39 pls.

Applin, P. L., and Applin, E. R., 1965, The Comanche Series and associated rocks in the subsurface in central and south Florida: U.S. Geol. Survey Prof. Paper 447, 86 p.

Bassler, R. S., and Kellett, Betty, 1934, Bibliographic index of Paleozoic Ostracoda: Geol. Soc. America Special Paper $1,500 \mathrm{p}$.

Bizon, J. J., 1958, Foraminifères et Ostracodes de l'Oxfordien de Villers-sur-Mer (Calvados): Rev. Inst. français Pétrole et Annales Combust. Liquides, v. 13, p. 345.

Bonnema, J. H., 1940, Ostracoden aus der Kreide des Untergrundes der nordöstlichen Neiderlande: Natuurh. Maandblad, v. 27, p. 91-95, 104-108, 115-118, 129-132, pls. 1-4.

Bosquet, J., 1852, Description des Entomostracés fossiles des terrains Tertiares de la France et de la Belgique: Acad. royale Sci., Belgique, Mém. cour. et sav. étrang., v. 24, 142 p., 6 pls.

-1854, Monographie des Crustacés fossiles du terrain Crétacé du Duché de Limbourg: Commission pour la description et la carte géol. de la Néerlande, Mém., v. 2, p. 1-139, 10 pls.

Brady, G. S., 1868, A monograph of the Recent British Ostracoda: Linn. Soc., London, Trans., v. 26, p. 353-495, pls. 23-41. (Published 1870?)

1870, Notes on Entomostraca taken chiefly in the Northumberland and Durham district (1869) : Nat. Hist. Soc. Northumberland and Durham, Newcastle upon Tyne, Trans., v. 3, p. 361-373, pls. 12-14.

Brady, G. S., and Norman, A. M., 1889, A monograph of the marine and fresh-water Ostracoda of the North Atlantic and of northwestern Europe, Section 1, Podocopa: Royal Dublin Society Trans., ser. 2, v. 4, p. 63-270, pls. 8-23.

Brady, G. S., and Robertson, D., 1870, The Ostracoda and Foraminifera of tidal rivers: Ann. and Mag. Nat. Hist., ser. 4 , v. 6 , pl. 33 , pls. 1-10.

1872 , Contribution to the study of the Entomostraca. No. VI. On the distribution of the British Ostracoda: Ann. and Mag. Nat. Hist., ser. 4, v. 9, p. 48-70, pls. 1, 2. 
Brand, Erich, and Malz, Heinz, 1962, Ostracoden-Studien im Dogger. 5; Glyptocythere, n.g.: Senckenberg. Lethaea, v. 43, p. 433-435.

1966, Ostracoden Studien im Dogger. 6; Die Arten der Gattung Glyptocythere Brand und Malz, 1962, im NWdeutschen Dogger: Senckenberg. Lethaea, v. 47, p. 481536.

Brown, P. M., 1957, Upper Cretaceous Ostracoda from North Carolina: North Carolina Dept. Conserv. and Devel. Bull. 70, 28 p., 7 pls.

Brown, P. M., Miller, J. A., and Swain, F. M., 1972, Structural and stratigraphic framework, and spatial distribution of permeability of the Atlantic Coastal Plain, North Carolina to New York: U.S. Geol. Survey Prof. Paper 796, $79 \mathrm{p}$.

Calahan, L. W., 1939, Diagnostic fossils of the Ark-La-Tex area: Shreveport Geol. Soc. Guidebook, 14th Ann. Field Trip, p. 36-56, pls. 1-9.

Damotte, Renée, and Grosdidier, Emanuel, 1963, Quelques Ostracodes du Crétacé Inférieur de la Champagne Humide. 2-Aptien: Rev. Micropaléontologie, v. 6, p. 153168,3 pls.

Deroo, G., 1956, Études critiques au sujet des Ostracodes marins du Crétacé inférieur et moyen de la Champagne Humide et du Boulonnais: Rev. Inst. français Pétrole et Annales Combust. Liquides, v. 11, p. 1499-1545, pls. $1-5$.

Galeeva, L. I., 1955, Cretaceous ostracod succession of Mongolian Peoples Republic Ministry Petroleum Industry: All-Union Petroleum Scientific Research Geol. Exploration Inst. Moscow (VNIGRI), (State Sci. Tech. Pub. House), 64 p., 15 pls.

Grekoff, N., 1951, Quelques Ostracodes nouveaux du Senonien Supérieur du Caméroun: Rev. Inst. français Pétrole, et Annales Combust. Liquides, v. 6, p. 53-59, pls. 1, 2.

- 1963, Contribution à l'étude des Ostracodes du Mesozoïque moyen (Bathonian-Valanginian) du Bassin de Majunga, Madagascar: Rev. Inst. français Pétrole et Annales Combust. Liquides, v. 18, p. 1709-1762, 10 pls.

Hartmann, Gerd, 1953, Iliocythere meyer-abichi n. sp., ein Ostracode des Schlickwattes von San Salvador: Zool. Anz., v. 151, p. 310-316, 17 figs.

Holland, W. C., 1934, The Ostracoda of the Ninevah Limestone of Pennsylvania and West Virginia: Annals Carnegie Mus., v. 22, p. 343-350, 1 pl.

Hornibrook, N. de B., 1952, Tertiary and Recent marine Ostracoda of New Zealand: New Zealand Geol. Survey, Paleo. Bull. 18, 82 p., 18 pls.

Howe, H. V., 1962, Ostracod taxonomy: Baton Rouge, Louisiana State Univ. Press, $366 \mathrm{p}$.

Howe, H. V., and Laurencich, Laura, 1958, Introduction to the study of Cretaceous Ostracoda: Baton Rouge, Louisiana State Univ. Press, $536 \mathrm{p}$.

Imlay, R. W., 1944, Correlation of Lower Cretaceous formations of the coastal plain of Texas, Louisiana, and Arkansas: U.S. Geol. Survey Oil and Gas Prelim. Chart No. 3.

Jones, T. R., 1849, A Monograph of the Entomostraca of the Cretaceous Formation of England: Palaeontographical Soc. London, 40 p., 7 pls.

-1850, Class Crustacea, in King, William, A Monograph of the Permian fossils of England: Palaeontographical Soc., London, p. 58-66, pls. 6, 17, 18 .

-1862, Monograph of the fossil Estheridae: Palaeontographical Soc. London, p. 1-134, pls. 1-5.
189.3, On some fossil Ostracoda from S.W. Wyoming and from Utah, U.S.A.: Geol. Mag., Dec. 3, v. 10, p. 385391 , pl. 15.

Jones, T. R., and Hinde, G. J., 1890, Supplementary Monograph of the Cretaceous Entomostraca of England and Ireland: Palaeontographical Soc. London, 70 p., 4 pls.

Kashevarova, N. P., 1958, New species of Ostracoda from Upper Permian sediments (Ufmian and Tatarian) of Southern Timian and Voga-Ural Region, in Microfauna U.S.S.R., v. 9: All-Union Petroleum Scientific Research Geol. Exploration Inst. (VNIGRI) Trans., no. 115, p. 301-339, 4 pls., 7 text figs.

Kaye, Peter, 1963a, The interpretation of the Mesozoic ostracod genera of the family Cytherideidae Sars, 1925: Rev. Micropaléontologie, v. 6, p. 23-40, pls. 1-3.

$-1963 \mathrm{~b}$, Ostracoda of the subfamilies Protocytherinae and Trachyleberidinae from the British Lower Cretaceous : Paläont. Zeitschr., v. 37, p. 225-238, pls. 18, 19.

- $1963 \mathrm{c}$, The ostracod species Orthonotacythere inversa (Cornuel) and its allies in the Speeton Clay of Yorkshire: Palaeontology, v. 6, p. 430-439, pl. 61.

1964, A revision of the Ostracoda from the Bargate Beds in Surrey: Palaeontology, v. 7, p. 317-330, pls. 54, 55 .

-1965a, Ostracoda from the Aptian of the Isle of Wight, England: Paläont. Zeitschr., v. 39, p. 35-50, 8 pls.

1965b, Some new British Albian Ostracoda: Bull. Brit. Mus. (Nat. History), Geology, v. 11, p. 217-253, 11 pls.

Kaye, Peter, and Barker, D., 1965, Ostracoda from the Sutterby Marl, (Upper Aptian) of South Lincolnshire: Palaeontology, v. 8, p. 375-390, pls. 48-50.

1966, Ostracoda from the upper Tealby Clay (Lower Barremian) of South Lincolnshire: Palaeontology, v. 9, p. 208-219, pl. 33.

Kellett, Betty, 1943, Permian ostracodes: Jour. Paleontology, v. 17, p. $615-638$.

Klie, Walter, 1939, Brackwasserostracoden von Nordostbrasilien: Zool. Jahrb., Abt. Fauna Systematik ökologie u. Geographie, Jena, v. 72, p. 359-372, 10 figs.

Loranger, D. M., 1951, Useful Blairmore microfossil zone in central and southern Alberta, Canada: Am. Assoc. Petroleum Geologists Bull., v. 35, p. 2348-2367, 3 pls.

-1954, Useful Blairmore microfossil zone in central and southern Alberta, Canada, in Clark, L. M. (ed.), Western Canada Sedimentary Basin: Tulsa, Okla., Am. Assoc. Petroleum Geologists, p. 279-296, pls. 1-3.

Liubimova, P. S., 1955, Ostracoda of the middle Mesozoic formations of the central Volga region and the common sirt, in Liubimova, P. S., and Khabarova, T. H., Ostracoda of the Mesozoic sediments of the Volga-Ural region: AllUnion Petroleum Scientific Research Geol. Exploration Inst. (VNIGRI) Trans., n.s., no. 84, p. 1-189, pls. 1-13.

1956, Ostracoda of Cretaceous formations of the eastern part of the Mongolian National Republic and their importance to stratigraphy: All-Union Petroleum Scientific Research Geol. Exploration Inst. Leningrad (VNIGRI) Trans., n.s., no. 93, p. 1-174, pls. 1-25.

M'Coy, Frederick, 1849, On the classification of some British fossil Crustacea with notices of new forms in the university collection at Cambridge: Annals and Mag. Nat. History, s€r. 2, v. 4, p. 161-179, 330-355, 392-414.

Maher, J. C., 1965, Correlations of Mesozoic and Cenozoic rocks along the Atlantic coast: Tulsa, Okla., Am. Assoc. Petroleum Geologists, $18 \mathrm{p}$.

Mandelstam, M. I., 1947, Ostracoda from Middle Jurassic de- 
posits of the Magislaka Peninsula, in Microfauna, Petrol. Occ., Cauc., Emba, and Central Asia: All-Union Petroleum Scientific Research Geol. Exploration Inst. (VNIGRI), State Sci. Tech. Pub. House, Leningrad-Moscow, p. 239-262, 2 pls.

Mandelstam, M. I., and others, 1956, Ostracoda, in Paleont., new Families, new Genera: Material of Paleontology, n.s., v. 12, Trans. All-Union Scientific Research Geol. Inst. Ministry of Geol., Moscow, p. 106-109, 139-142, pl. 26.

1957, New genera of Ostracoda in the families Cypridae and Cytheridae: All-Union Palaeont. Soc., Annual, Moscow, v. 16, p. 165-193, pls. 1-4.

Martin, G. P. R., 1940, Ostracoden des Norddeutschen Purbeck und Wealden: Senckenbergiana, v. 22, p. 275-361, pls. 1-13.

-1961, Die Gattung Fabanella, n.g. (Ostracoden) in NW-deutschen Malm und Wealden: Senckenberg. Lethaea, v. 42, p. 181-195, pl. 1 .

Mertens, E., 1956, Zur Grenzziehung Alb/Cenoman in Nordwestdeutschland mit Hilfe von Ostracoden: Geol. Jahrb., v. 72 , p. 173-230, pls. 8-14.

Moore, R. C., ed., 1961, Ostracoda, Part Q of Treatise on Invertebrate Paleontology: Geol. Soc. America, 442 p., 334 figs.

Müller, G. W., 1894, Die Ostracoden des Golfes von Neapel und der Angrenzenden meeres-Abschnitte: Naples Sta. Zool. Fauna und Flora des Golfes von Neapel 21 Mon., p. i-viii, 1-140, pls. 1-40.

Murray, G. E., 1961, Geology of the Atlantic and Gulf Coastal Province of North America: New York, Harper and Brothers, $692 \mathrm{p}$.

Neale, J. W., 1962, Ostracoda from the type Speeton clay (Lower Cretaceous) of Yorkshire: Micropaleontology, v. 8, p. $425-484,13 \mathrm{pls}$.

Neale, J. W., and Kilenyi, T. I., 1961, New species of Mandelstamia (Ostracoda) from the English Mesozoic: Palaeontology, v. 3, p. 439-449, pl. 71 .

Oertli, H. J., 1957, Ostracodes du Jurassique supérieur du Bassin de Paris (Sontage Vernon 1): Rev. Inst. français Pétrole et Annales Combust. Liquides, v. 12, p. $647-$ 695,7 pls.

- 1958, Les Ostracodes de l'Aptien-Albien d'Apt: Rev. Inst. français Pétrole et Annales Combust. Liquides, v. 13, p. 1499-1537, pls. 1-9.

Orlov, Yu. A. (director), 1961, Ostracoda (E. N. Tschsernysheva, editor) in Arthropoda Volume of Basic Paleontology: State Sci.-Tech. Pub. House, Moscow, p. 264-421, figs. 600-1238, pl. 17.

Peck, R. E., 1941, Lower Cretaceous Rocky Mountain nonmarine microfossils: Jour. Paleontology, v. 15, no. 3, p. 285-304, pls. 42-44.

-1951, Nonmarine ostracodes-the subfamily Cyprideinae in the Rocky Mountain area: Jour. Paleontology, v. 25 , p. 307-320, pls. 48-50.

Reinemund, J. A., 1955, Geology of the Deep River coal field, North Carolina: U.S. Geol. Survey Prof. Paper 246, $159 \mathrm{p}$.

Reuss, A. E., 1846, Die Versteinerungen der Bohmischen Kreide Formation: Stuttgart, E. Schweizerbart, Abt. II, p. 59-148, pls. 14-51.

Roemer, F. A., 1840, Die Versteinerungen des norddeutschen Kreidegebirges: Hannover, 144 p., 16 pls.

Roth, Robert, 1928, Monoceratina; a new genus of Ostracoda from the Pennsylvanian of Oklahoma: Jour. Paleontology, v. 2, p. 15-19, illus.

Sars, G. O., 1866, Oversigt af Norges Marine Ostracoder: Norske Vidensk.-Akad. Forh. (1865) 1866, p. 1-130.
-1924, The fresh-water Entomostraca of the Cape Province (Union of South Africa) ; Part II, Ostracoda: South African Mus., Annals, v. 20, p. 105-193, pls. 2-20.

Scott, H. W., 1944, Muscle scar patterns on some upper Paleozoic Ostracoda: Jour. Paleontology, v. 18, p. 162171.

Scott, H. W., and Summerson, C. H., 1943, Nonmarine Ostracoda from the Lower Pennsylvanian in the southern Appalachians and their bearing on intercontinental correlation: Am. Jour. Sci., v. 24, p. 653-675, 2 pls., 1 text fig.

Sharapova, E., 1937, The stratigraphy of Mesozoic deposits of the Emba region on the basis of Ostracoda: Geol. Oil Inst., Trans., ser. A, no. 106, p. 69-86, pls. 1, 2.

Sohn, I. G., 1964, Significance of Triassic ostracodes from Alaska and Nevada: U.S. Geol. Survey Prof. Paper 501D, p. D40-D42.

1969, Nonmarine ostracodes of Early Cretaceous age from Pine Valley quadrangle, Nevada: U.S. Geol. Survey Prof. Paper 643-B, 9 p., 2 pls.

Spizharsky, T. N., 1937, Ostracoda of the Kulchugino Series of the coal-bearing strata of the Kuznetsk Basin: Central Geol. Prospecting Inst., Leningrad-Moscow, Trans. Fasc. 97, p. 139-171, 1 pl.

Stephenson, M. B., 1938, Miocene and Pliocene Ostracoda of the genus Cytheridea from Florida: Jour. Paleontology, v. 12 , p. 127-148, pls. 23,24 , text figs. 1-20.

Swain, F. M., 1946, Upper Jurassic Ostracoda from the Cotton Valley Group in northern Louisiana; the genus Hutsonia: Jour. Paleontology, v. 20, p. 119-129, pls. 83, 84. 1949, Upper Jurassic of Northeastern Texas: Am. Assoc. Petroleum Geologists Bull. 33, p. 1206-1250.

1952, Ostracoda from wells in North Carolina; Part 2, Mesozoic Ostracoda: U.S. Geol. Survey Prof. Paper 234-B, p. B59-B93, pls. 8, 9.

Swain, F. M., and Brown, P. M., 1964, Cretaceous Ostracoda from wells in the southeastern United States: North Carolina Dept. Conserv. and Devel. Bull. 78, 55 p., 5 pls.

Swartz, F. M., and Swain, F. M., 1946, Ostracoda from the Upper Jurassic Cotton Valley Group of Louisiana and Arkansas: Jour. Paleontology, v. 20, p. 362-373, pls. 52, 53.

Triebel, Erich, 1938, Die Ostracoden der deutschen Kreide; 2, Die Cytheridea-Arten der unteren Kreide: Senckenbergiana, v. 20, p. 471-501, pls. 1-6.

1940, Die Ostracoden der deutschen Kreide; 3, Cytherideinae und Cytheridae aus der unteren Kreide: Senckenbergiana, v. 22, p. 160-227, 10 pls.

1941, Zur Morphologie und ökologie der fossilen Ostracoden: Senckenbergiana, v. 23, p. 294-400, 15 pls.

Triebel, Erich, und Klingler, W., 1959, Neue Ostracoden-Gattungen aus dem deutschen Lias: Geol. Jahrb., v. 76, p. $335-372,9$ pls. 1 fig.

Vanderpool, H. C., 1928, Fossils from the Trinity Group (lower Comanchean): Jour. Paleontology, v. 2, p. 95-107, pls. $12-14$.

1930, Cretaceous section of Maverick County, Texas: Jour. Paleontology, v. 4, p. 252-258.

1933, Upper Trinity microfossils from southern Oklahoma: Jour. Paleontology, v. 7, p. 406-411, pl. 49.

Veen, J. E. van, 1935, Die Cytheridae der Maastrichter Tuffkreide und des Kunrader Korallenkalkes von Süd-Limburg; II, Die Gattung Cytheridea: Natuurh. Maandblad v. 24, p. 83-112, pls. 1-4.

White, C. A., 1895, The Bear River Formation and its characteristic fauna: U.S. Geol. Survey Bull. 128, 108 p., 11 pls. 


\section{N D E X}

[Italic numbers indicate descriptions]

\section{A \\ Page}

acaudatum, Eocytheropteron

acuminata, Schuleridea _._._._- 8, 10,27

Aequacytheridea -_-_-_-_-_-_-_-- 27

alata, Klieana --_-_-_-_-_---- 46

Schuleridea

alexandrina, Bairdia

amygdaloides, Asciocythere _._._._ 11, 22

brevis, Cytheridea

annulopapillata, Centrocythere _... 5,39

anterofossulata, Schuleridea $---5,10,27$; pl. 6

anumbonata, Paraschuleridea _-_-_-- 29, 30

Apatocythere lanceolata _._...... 31 leguminoidea _-_-_._- 31

tumidosa -

aptensis, Protocythere _..._._. 5, 44; pl. 9

Arculicythere -.-_-_- 34 defluxa _-_._-_._. 35

Asciocythere -- 21, 22, 24, 25 amygdaloides _..._...

elongata _macropunctata _..._._. 5, 23 ; pls. 4, 5 rotunda _._._._._. 5, 11, 22, 23; pl. 4 rugosa _..._._. $5,10,24 ;$ pls. 3,4 triangularis _-_-_-_-_-_. $5,11,24$ attenuata, Hutsonia

collinsensis _- 4,5,10,41, 42; pl. 8

atypica, Orthonotacythere -_- 35

Bairdia alexandrina _-_-_- 12 fulva - -

Bairdiocypris _._._._. 3,10

berryi, Hovellites _-_._-_._-

bicornis, Cythereis _-_-_-_-_-_. 12

bicostatum, Metacytheropteron -

bifurcata, Monoceratina -

bilobata, Schuleridea _-_-_-_- 27

bilobatum, Cytheropteron _..-_-_-_ 36

bispinosa, Cypridea - 13

bispinosus, Cypridea ventrosa

Bisulcocypris ----

blanda, Orthonotacythere _._._. 10, 35, 40

blandoidea, Hutsonia -- 4, 5, 10, 35, 39; pls. 8,9 bosquetoidea, Dolocyther-

idea _- $5,10,11,12,21 ; \mathrm{pl} .3$

brevis, Cytheridea amygdaloides _..._ 23 Bythocypris rotundus _-_._._.

Bythocytheremorpha _.._-_-_-_- 19

Bythocytheridae

caledonensis, Dolocytheridea

callosa, Otocythere

Candona rogersii _.--_-_-_-_-_-_-_- 16

catalounia, Orthonotacythere _...-.- 35

Caudites ---- 48

Centrocythere -.-...-_-_- 39

annulopapillata _._._-_-_-_-_ 5,39

denticulata _-_._-_-_._- 39

Clithrocytheridea halifaxensis
Page

Coahuilan Age

4

Coahuilan Stage _-_-_-_._- 3

collinsensis, Hutsonia _._._._._. 42,43

Hutsonia collinsensis _-_- $4,5,10,41,42 ; \mathrm{pl} .8$

attenuata, Hutsonia _._. $4,5,10,41,42 ; \mathrm{pl} .8$

collinsensis, Hutsonia ______ $4,5,10,41,42 ; \mathrm{pl} .8$

micropunctata, Hutsonia -

$4,5,10,42 ; \mathrm{pl} .8$

subsp., Hutsonia _-_.-- 4, 5, 10,43; pl. 8

Comanchean Age _........... 4

Comanchean Stage _... 3

Cretaceous _. 1,3

Albian -

Aptian -

Cenomanian _._- 3

Neocomian _... 3, 10

cristata, Cythereis _. 48

curta, Paraschuleridea _._._-- 4, 5, 29; pl. 7

Cypridea _._.

bispinosa --_-_-_-_-_-_-_-_-_ 13

dequeenensis _._._.

diminuta _..._. 5,13

diminutus -..- 13

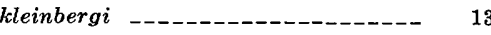

menevoides _._._._._. $4,5,13 ; \mathrm{pl} .1$

modica _-_-_._._- 15

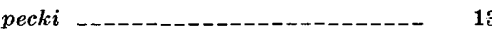

tuberculata gypsumensis _...-_- 14

wyomingensis _-_-_-_._- 14

ventrosa bispinosus _._._._. 13

wyomingensis _._._._._. 5,$14 ; \mathrm{pl} .1,3$

sp _....... $4,5,14 ; \mathrm{pl} .1$

Cyprideinae -

Cyprididae -

Cypridopsinae _.

Cypris granulosa

Cytheracea, family uncertain _._._. 49

Cythere complexa

declivis _-_-_-_._- 33

ornata -

Cythereis _- 46

bicornis - 12

cristata -_._-_-_- 48

dentonensis _...

eaglefordensis _._....... 12

fredricksburgoides _._-___._._. 12

glabrella _-_-_-_. 11

lamplughi _.

ornatissima

pittensis - praeornata 11

praeornata

rugosissima _.

simulonuda

sp _...

Cytherella _- 12

ovata _-______________ 5, 12; pl. 1

sp. 1 _.

sp. 2 . 5,$12 ; \mathrm{pl} .1$

Cytherellidae --_-_-_-_- 12

Cytheridea amygdaloides

brevis _- 23

hannai
Page

Cytheridea-Continued

matsoni _..- 26

ovata --_-

rotundus --- 23

trinitiensis -

(Haplocytheridea) ------_------ 28

thoerenensis -

Cytherideidae -

Cytherideinae --_- 25

Cytherina hilseana

ornatissima -

ovata -

triplicata

Cytheropsis -

Cytheropterina --_-_-_-_-_-_-- 36

Cytheropteron bilobatum _._._._. 36

tumidum

(Cytheropteron) eximuium _..-_ 12

(Eocytheropteron) _..........- 36

trinitiensis - 36

tumidum _- 37

tumoides 37

(Cytheropteron) eximium,

Cytheropteron -..-_- 12

Cytherura _-_-_- 37

Cytheruridae - 33

D

Darwinella _._- 16

Darwinula emmonsii -

rogersii _...

subquadrata _-_._._._. 3, 16; pls. 1, 2

sp. 1 _

sp. 2 _.

sp. 3 -

sp. 4 - 4 ; 1

Darwinulidae _. 16

defluxa, Arculicythere _-_._-_._- 35

delicatula, Orthonotacythere

denticulata, Centrocythere _-_._-_ 39

dentonensis, Cythereis _._._._. 5, 47; pl. 9

dequeenensis, Cypridea _._...- 5, 13; pl. 1

derooi, Schuleridea _-_-_-_-_-_-_ 27

diglypta, Orthonotacythere -..-_- 35

diminuta, Cypridea

diminutus, Cypridea

dimorphica, Schuleridea _-_._-_-_- 27

Dolocytheridea bosquetoidea _._._. 5, 10,11, 12, 21; pl. 3 caledonensis _._._._._._._._. 11

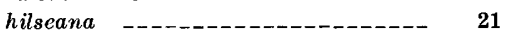
intermedia _... minuta _oertlii _typica -_-_-_-_- 21

wolburgi _. 21

(Dolocytheridea), Cytheridea

Dolocytherideinae -.-_-_-_-_-_- 20

Durango Stage _._. $3,4,9$

\section{E}

eaglefordensis, Cythereis _-_-_-_-_ 12 elegans, Metacytheropteron 
Page

elongata, Asciocythere _._.-5, 10, 11, 22; pl. 5 emmonsii, Darwinula _-_-_-_-_-- 17

Eocytheropteron _._._- 36 acaudatum _-_-_-_-_._- 11 greenvillensis saturnoformis _.._- 36 trinitiensis _._._._. 5, 11, 36; pl. 8 tumidum _-_. tumoides _. venoides _..__. $5,11,37$ sp _-....... 10

(Eocytheropteron), Cytheropteron --- 36 trinitiensis, Cytheropteron _..._- 36 tumidum, Cytheropteron tumoides, Cytheropteron _.....- 37

Eucythere - 33

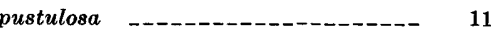
semiglypta _. Eucytherinae -

Eucytherura sp _ eximium, Cytheropteron

(Cytheropteron) -.- 12

\section{$\mathbf{F}$}

Fabanella

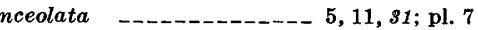

leguminoidea _._._.___ $5,11,31 ; \mathrm{pl} .7$ prima _._._- 31 tumidosa _._.

sp _-________ $5,10,32 ; \mathrm{pl} .7$ facilis, Mandelstamia _. 49 fiscellaformis, Taxodiella _..._... 49 fissicostis, Isocythereis _._._-___- 48, 49 fordensis, Orthonotacythere _..._... 36 Fossocytheridea lenoirensis _..._._. $5,11,25 ; \mathrm{pl} .6$ Fredericksburg Stage _._._____- 3, 11 fredricksburgoides, Cythereis _-_-_- 12

fulva, Bairdia _._. 15

G

glabrella, Cythereis

Glyptocythere goerlichi, Pseudobythocythere Gomphocythere silvana goodlandensis, Para graysonensis, Haplocytheridea greenvillensis, Eocytheropteron -...gutschickia H

halifaxensis, Clithrocytheridea hannai, Cytheridea _-___-_-_-_- 35

Haplocytheridea graysonensis _...-.-- 12 multiclefta -_-_-_-_-_-_-_-_- 11 (Haplocytheridea), Cytheridea _-...-- 28 thoerenensis, Cytheridea _..._..- 28 hatterasensis, Schuleridea - 5, 11,27,28; pl. 6 Hilboldtina -.---_-_-_-_-_-_----- 3

hilseana, Cytherina _........... 20 Dolocytheridea _._. 21

Howellites berryi _._._._.

Hutsonia _._._._._. 10,35, 36, 39, 41, 44 blandoidea _.__ $4,5,10,35,39$; pls. 8,9 collinsensis _._._._. attenuata _._. $4,5,10,41,42 ; \mathrm{pl} .8$ collinsensis _.._ 4, 5, 10,42,52; pl. 8 micropunctata _-__- 4, 5, 10,42; pl. 8 subsp microrugosa _-_._._._. $5,11,43 ;$ pl. 8
Hutsonia-Continued

rugata

rugosa

truncata _._. 10

vulgaris _._._. 39

sp _-_.

sp., immature _........ 5, 44; pl. 8

I

Ilyocyprididae

Ilyocypris tumida

Ilyocythere

inornata, Orthonotacythere --_- 35

Protocythere _-_._-____- 5, 44; pl. 9 intermedia, Dolocytheridea inversa, Orthonotacythere --_-_-_ 35 tuberculata, Orthonotacythere _.. 35,36

Isocythereis - 48 fissicostis

$\mathbf{J}$

jonesiana, Schuleridea __._____ 27 Jurassic _..... 1, 3, 10

Kimmeridgian _._._._. 3 Portlandian-Purbeckian _-_._-_-- 3

Juvenix _... 38 pseudocuspidatus _... 38 sp _-

\section{$\mathbf{K}$}

kleinbergi, Cypridea alata sp

\section{L}

La Casita Stage _. lacustris, Schuleridea lamplughi, Cythereis _._._._- 5, 47; pl. 9 lanceolata, Apatocythere -- 31 Fabanella leguminoidea, Apatocythere _..._... 31

Fabanella _._._._. 5, 11, 31; pl. 7 lenoirensis, Fossocytheridea longispina, Monoceratina _-_-_-_- 19

Looneyella

\section{M}

Macrodentina obliqua -_-_-_-_-_ 8 macropunctata, Asciocythere -- 5,23; pls. 4, 5 Mandelstamia facilis -

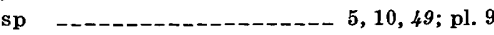
martini, Protocythere _._._._. 34 matsoni, Cytheridea menevoides, Cypridea

$$
\text { (Cypridea) _-_-_-_ 4, 5, 13; pl. } 1
$$

Metacytheropteron _... 33,34 bicostatum _..._._. 4, 5, 11,34; pl. 8 elegans micropunctata, Hutsonia collinsensis __- 4,5,10,42; pl. 8

microrugosa, Hutsonia _._._- 5, 11, 43; pl. 8 minuta, Dolocytheridea _._._._._ 21 minutissima, Orthonotacythere _-___- 35 modica, Cypridea

Monoceratina

ventrale

bifurcata

longispina

sp multiclefta, Haplocytheridea 11
$\mathbf{N}$

Page

nuda, Ovocytheridea

25

Nuevo León Stage

3,4

o

obliqua, Macrodentina - 8 odomensis, Perissocytheridea _-_._ 5, 11, 26 oertlii, Dolocytheridea $--5,10,11,12$, 22; pl. 3 ornata, Cythere _..._. 46 ornatissima, Cythereis _-_-_-_-_-_ 12 Cytherina Orthonotacythere atypica -.-_- 35 blanda _catalounia _delicatula _..._. diglypta fordensis _-_._._. 36 inornata _. inversa -.- 35 inversa tuberculata _..._...... 35, 36 minutissima _problematica _._. 39 spinifera -sp. A Otocythere callosa _._._- 34 sp _... ovata, Cytherella _._._._._. 5, 12; pl. 1 Cytheridea _._. Cytherina -..._- 12 Ovocytheridea nuda -. producta _. sp ___.

Paracyprididae ---

Paracypris _-_._- 15 goodlandensis _._-_._. 5,15 polita _siliqua _-_._-_._. sp Paraschuleridea -.- 29, 30 anumbonata _......... curta _..._....... $4,5,29 ; \mathrm{pl} .7$ postumbonata _._._- 5, 10,29, 30; pl. 7 twifordensis _..._- 4, 5, 10, 29, 30; pl. 7 paratriplicata, Veenia _..... 45 Parexophthalmocythere -- 36 pecki, Cypridea _-_-_._._.-_ 13

Pennsylvanian pentagonalis, Schuleridea Perissocytheridea _-_-_-_-_-_-_--- 26 odomensis _._._._._._. 5, 11,26 Permian _...-_-_._- 3 pittensis, Cythereis _-_- 11 polita, Paracypris _._._. 15 Polycheles _.--_-_-_-_-_-_-16 16 stevensoni _...- 16 postumbonata, Paraschuleridea _- $5,10,29,30 ; \mathrm{pl} .7$ Potamocypris _-_-_-_-_- 15 sp $\ldots \ldots \ldots, 5,15 ; \mathrm{pl} .1$ praeornata, Cythereis _-_._._._. 5, 46 prima, Fabanella problematica, Orthonotacythere _...- 39 producta, Ovocytheridea _-___-_-_ 25

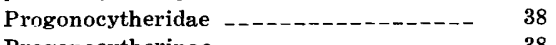
Progonocytherinae _._. 38

Protocythere -_-_-_._- 44, 45 aptensis _... inornata _..._. martini _sp. 1 sp. 2 _. 


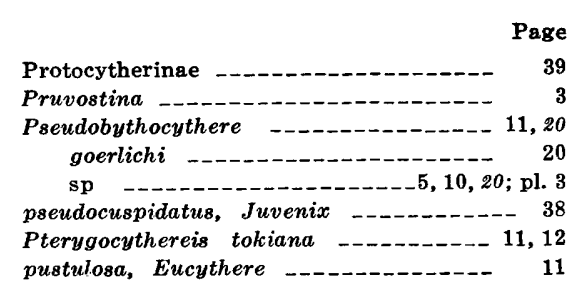

\section{$\mathbf{R}$}

rogersii, Candona _-.

Darwinula _...

rotunda, Asciocythere _._._._ 5, 11, 23; pl.

rotundus, Bythocypris _._.......- 22, 23

Cytheridea

rugata, Hutsonia _._._._. 36

rugosa, Asciocythere _._._- 5, 10, 24; pl. 3, 4

Hutsonia -

rugosissima, Cythereis _.._. 12

$\mathbf{s}$

Sabinasian Age saturnoformis, Eocytheropteron -..- 36

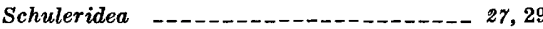

acuminata _..... 8, 10,27 alata _.... 27 anterofossulata _......- 5, 10,27; pl. 6 bilobata derooi -_dimorphica _-_._- 27 hammi - 27 hatterasensis __.____ 5, 11, 27, 28; pl. 6 jonesiana -_- lacustris __. pentagonalis _-

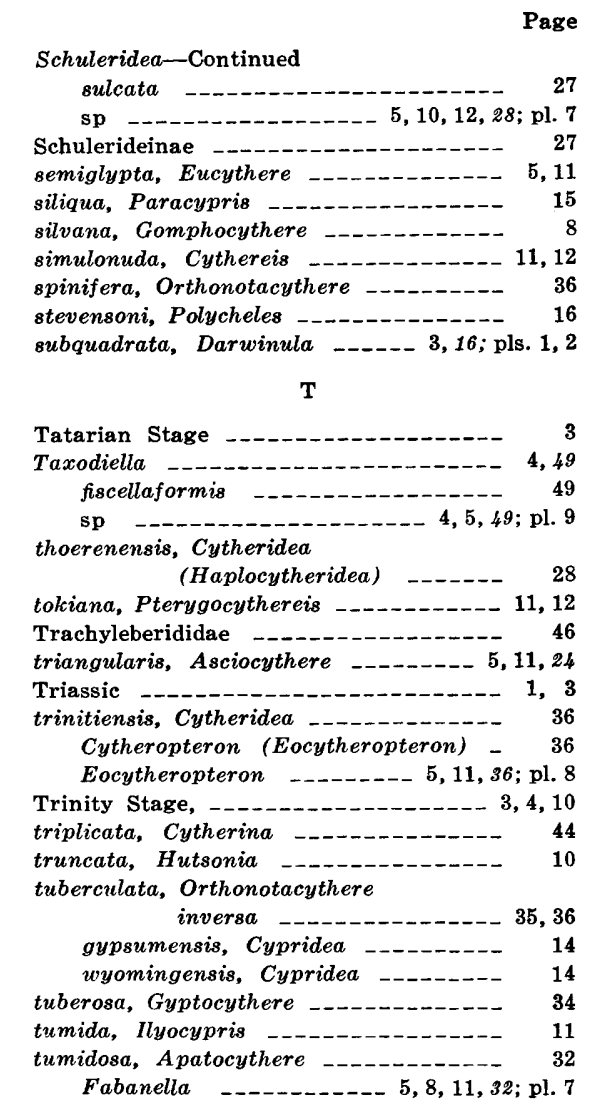

Cytheropteron _-_-_-_-_- 37 Cytheropteron (Eocytheropteron) -- 37 Eocytheropteron _._._._._._. 5, 37 tumoides, Cytheropteron

(Eocytheropteron) -.---- 37

Eocytheropteron _._._._._._. 5, 11, 37 twifordensis, Para-

schuleridea $\quad--4,5,10,29,30 ; \mathrm{pl} .7$

typica, Dolocytheridea _..._. 21

\section{$\mathbf{U}$}

Unit $\mathrm{C}$

Ufmian Stage

("Ulwellia"), Cypridea _._-_-_-_-_ 14

Unit D _. 4

Unit E - 4, 11

Unit $F$

Unit G

Unit $\mathrm{H}$

V

Veenia paratriplicata venoides, Eocytheropteron _-_._._ 5, 11, 37 ventrale, Monoceratina _-_._-_._-_ 19 ventrosa bispinosus, Cypridea vulgaris, Hutsonia

W

Washita Stage _..._. Whipplella -..- 3 wolburgi, Dolocytheridea _-_____- 21 wyomingensis, Cypridea _..._- 5, 14; pls. 1, 3 Cypridea tuberculata 



\section{PLATES 1-9}

Contact photographs of the plates in this report are available, at cost, from U.S. Geological Survey Library, Federal Center, Denver, Colorado 80225 


\section{PLATE 1}

Figures 1-5. Darwinula subquadrata Swain and Brown, n. sp. (p. 16).

1. Exterior view of holotype left valve, $\times 46$. Upper Triassic, Bethany Church locality, near Gulf, N.C. USNM 177721.

2. Exterior view of paratype left valve, $\times 46$. Same locality as fig. 1 . USNM 177722 .

3. Interior view of paratype left valve, $\times 46$, incomplete anterodorsally, showing adductor muscle scar. Same locality as fig. 1. USNM 177723.

4. Exterior of paratype left valve, $\times 40$. Same locality as fig. 1 . USNM 177724 .

5. Exterior of paratype right valve, $\times$ 44. Same locality as fig. 1 . USNM 177725 .

6, 7. Darwinula rogersii (Jones) (p. 16).

Exterior views of left valves, $\times 44$. Upper Triassic, Bethany Church locality, near Gulf, N.C. 6, USNM $177726 ; 7$, USNM 177727.

8. Darwinula? sp. 1 (p. 17).

Exterior of left valve, $\times$ 44. Upper Triassic, Bethany Church locality, near Gulf, N.C. USNM 177728.

9. Darwinula? sp. 2 (p. 18).

Exterior of a right valve, imperfect anteriorly, $\times$ 43. Upper Triassic, Bethany Church locality, near Gulf, N.C. USNM 177729.

10. Darwinula? sp. 3 (p. 18).

Right side of shell, $\times$ 48. Upper Triassic, Bethany Church locality, near Gulf, N.C. USNM 177730.

11. Darwinula? sp. 4 (p. 18).

Exterior of right valve, $\times$ 44. Upper Triassic, Bethany Church locality, near Gulf, N.C. USNM 177731.

12. Cytherella sp. 2 (p. 12).

a, Left side and, b, dorsal views of shell, $\times$ 62, NC-DA-OT-12, 6,096-6,106 feet, Unit G. USNM 177610.

13, 14. Paracypris sp. (p. 15).

13. Right side of shell, $\times 62$, NC-DA-OT-12, 7,146-7, 166 feet, Unit H. USNM 177619.

14. Right side of shell, $\times 62$, NC-DA-OT-12, 7,146-7,166 feet, Unit H. USNM 177620.

15. Potamocypris? sp. (p. 15).

Right side of shell, $\times 62$, NC-DA-OT-12, ‘7,836-7,846 feet, Unit H. USNM 177618.

16. Cytherella cf. C. ovata (Roemer) (p. 12).

a, Right side and, b, dorsal views, $\times$ 45, NJ-CM-OT-1, 3,418-3,428 feet, Unit F. USNM 177609.

17. Cytherella sp. 1 (p. 12 ).

Right side of shell, $\times$ 58, NC-CAR-OT-7, 3,080-3,090 feet, Unit E. USNM 177608.

18. Cypridea (C.) dequeenensis Swain and Brown (p. 13).

Left side of shell, $\times 62$, NC-DA-OT-12, 7,306-7,316 feet, Unit H. USNM 177613.

19, 20. Cypridea (C.) wyomingensis Jones (p. 14).

19. Right side of shell, $\times 58$, NC-DA-OT-11, 4,596-4,606 feet, Unit G. USNM 177611.

20. Right side of shell, $\times 58$, NC-DA-OT-11, 4,446-4,456 feet, Unit G. USNM 177612.

21. Cypridea (C.) menevoides Swain and Brown, n. sp. (p. 13).

Left side of holotype shell showing right valve overlap of left valve and smooth marginal zone, $\times 59$, NC-CUR-OT-12, 4,308-4,318 feet, Unit H. USNM 177617.

22-25. Cypridea (C.) sp. (p. 14).

22. Right side of a shell that may have been elongated by compaction, $\times 77$, NC-DA-OT-12, 7,146-7,156 feet, Unit H. USNM 177614.

23. Left side of shell, imperfect anteriorly, $\times$ 77, NC-DA-OT-12, 7,146-7,156 feet, Unit H. USNM 177615 .

24. Right side of a shell that is imperfect posteroventrally, $\times 77$, NC-DA-OT-12, 7,146-7,156 feet, Unit H. USNM 177616.

25. a., Left side of shell, $\times 110$; b, enlargement of part of anterior end of shell, $\times 550$, NC-DA-OT-12, 7,146-7,156 feet, Unit H. USNM 177616. 


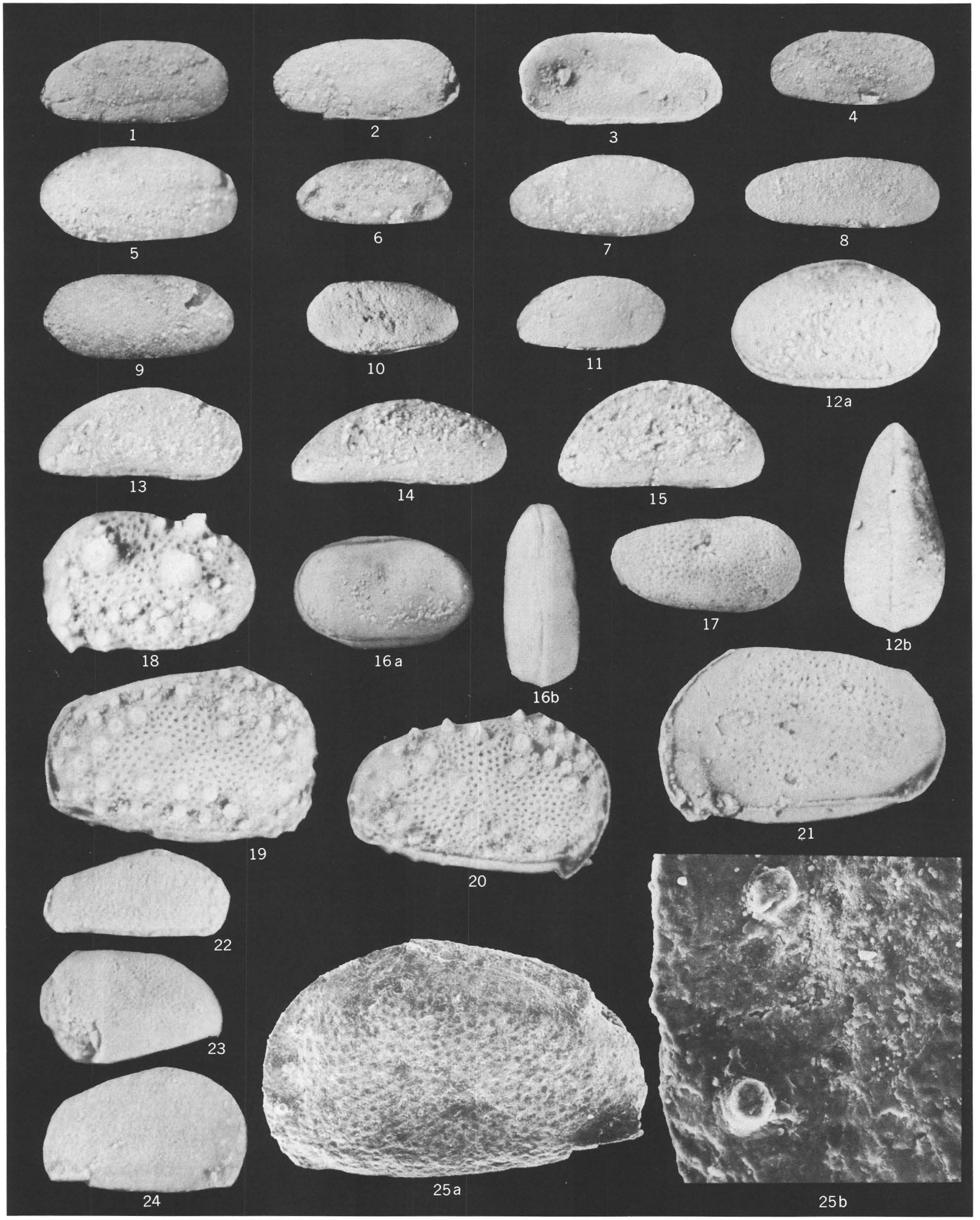

DARWINULA, DARWINULA?, CYTHERELLA, PARACYPRIS, POTAMOCYPRIS?, AND CYPRIDEA 


\section{PLATE 2}

Figures 1, 4. Darwinula? sp. 2 (p. 18).

1. a, Interior of left valve, $\times 110 ; b$, enlargement of surface showing recrystallized calcite surface which obscures labyrinthic nature of outer part of shell, $\times 500$. Undifferentiated sediments of Late Triassic age, near Carpenter, Wake County, N.C. USNM 177716.

4. a, Internal mold of left valve with dorsum tilted toward observer, $\times 105$; b, enlargement of mold surface, $\times 505$. Undifferentiated sediments of Late Triassic age, near Carpenter, Wake County, N.C. USNM 177719.

2, 3. Darwinula subquadrata Swain and Brown, n. sp. (p. 16).

2. a, Interior of left valve having dorsum tilted toward observer, $\times 225 ; \mathrm{b}$, enlargement of anterior end of valve showing recrystallized surface on which remnants of labyrinthic surface occur, $\times 560 ; c$, enlargement of a small part of shell surface showing calcite crystals, $X 11,200$. Undifferentiated sediments of Late Triassic age, near Carpenter, Wake County, N.C. USNM 177717.

3. Part of ventral surface of another shell showing labyrinthic structure that is poorly preserved due to recrystallization of shell material, $\times 505$. Undifferentiated sediments of Late Triassic age, near Carpenter, Wake County, N.C. USNM 177718.

5. Darwinula? sp. 1 (p. 17).

$a$, Internal mold of left valve showing slightly wrinkled interior surface, $\times 56$; b, enlargement of mold surface, $\times 1,112$. Undifferentiated sediments of Late Triassic age, near Carpenter, Wake County, N.C. USNM 177720. 

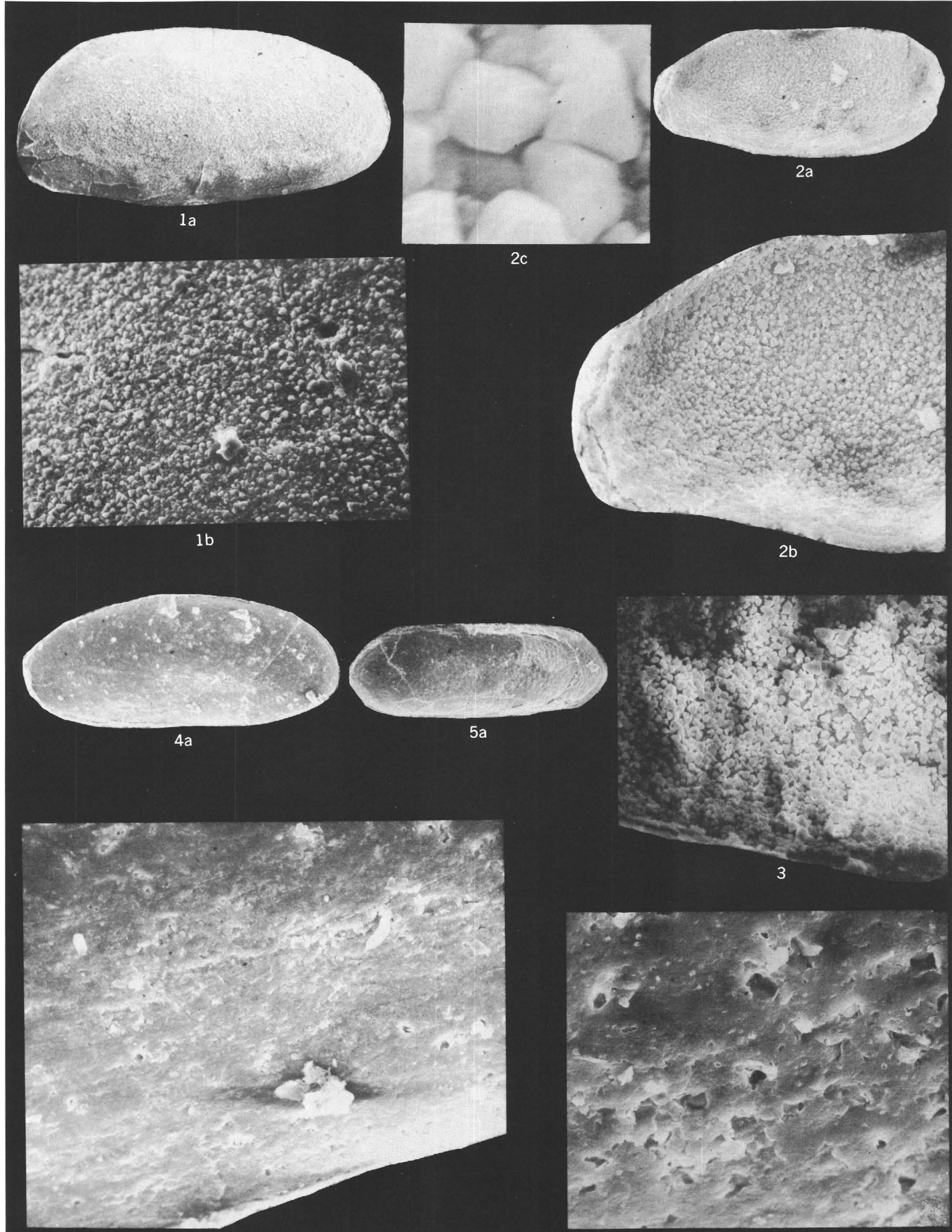


\section{PLATE 3}

Figure 1. Cypridea (C.) wyomingensis Jones (p. 14).

a, Right side of shell, $\times 110 ; b$, enlargement of part of surface showing normal canals, and surface pits, some of which have perforations in them but which are not true sieve nlates, $\times 1,100$; $c$, part of dorsal surface, showing pustules, $\times$ 550, NC-DA-OT-11, 4,596-4,606 feet, Unit G. USNM 177611.

2. Monoceratina? sp. (p. 19).

Right side of shell, $\times$ 70, NC-HY-OT-11, 5,016-5,026 feet, Unit G. USNM 177632.

3. Pseudobythocythere? sp. (p. 20).

Right side of shell, $\times$ 54, NC-DA-OT-12, 5,516-5,526 feet, Unit G. USNM 177633.

4, 5. Dolocytheridea oertlii Swain and Brown, n. sp. (p. 22).

4. Right side of paratype male shell, $\times 62$, NC-DA-OT-12, 5,536-5,546 feet, Unit G. USNM 177636.

5. Right side of holotype female shell, $\times$ 54, NC-HY-OT-11, 4,366-4,376 feet, Unit F. USNM 177637.

6, 7. Dolocytheridea? bosquetoidea Swain and Brown, n. sp. (p. 21).

6. Right side of paratype male? shell, $\times 55$, NC-HY-OT-11, 4,456-4,466 feet, Unit F. USNM 177634.

7. Right side of holotype female? shell, $\times$ 56, NC-HY-OT-11, 5,096-5,106 feet, Unit G. USNM 177635.

8-12. Asciocythere? rugosa Swain and Brown, n. sp. (p. 24).

8. Left side of paratype, $\times 56, \mathrm{NC}-\mathrm{HY}-\mathrm{OT}-11,5,016-5,026$ feet, Unit G. USNM 177642 .

9. Right side of holotype, $\times 56$, NC-HY-OT-11, 5,016-5,026 feet, Unit G. USNM 177643 .

10. Left side of paratype male shell, $\times 56, \mathrm{NC}-\mathrm{HY}-\mathrm{OT}-11,5,016-5,026$ feet, Unit G. USNM 177644.

11. Right side of paratype female shell, $\times$ 56, NC-HY-OT-11, 5,016-5,026 feet, Unit G. USNM 177645 .

12. a, Left side of a paratype shell, $\times 110$; b, enlargement of anterior surface showing several normal canals, $\times 550$; c, enlargement of area shown in " $b$ ", $\times 1,100, \mathrm{NC}-\mathrm{HY}-\mathrm{OT}-11,5,016-5,026$ feet, Unit G. USNM 177646. 

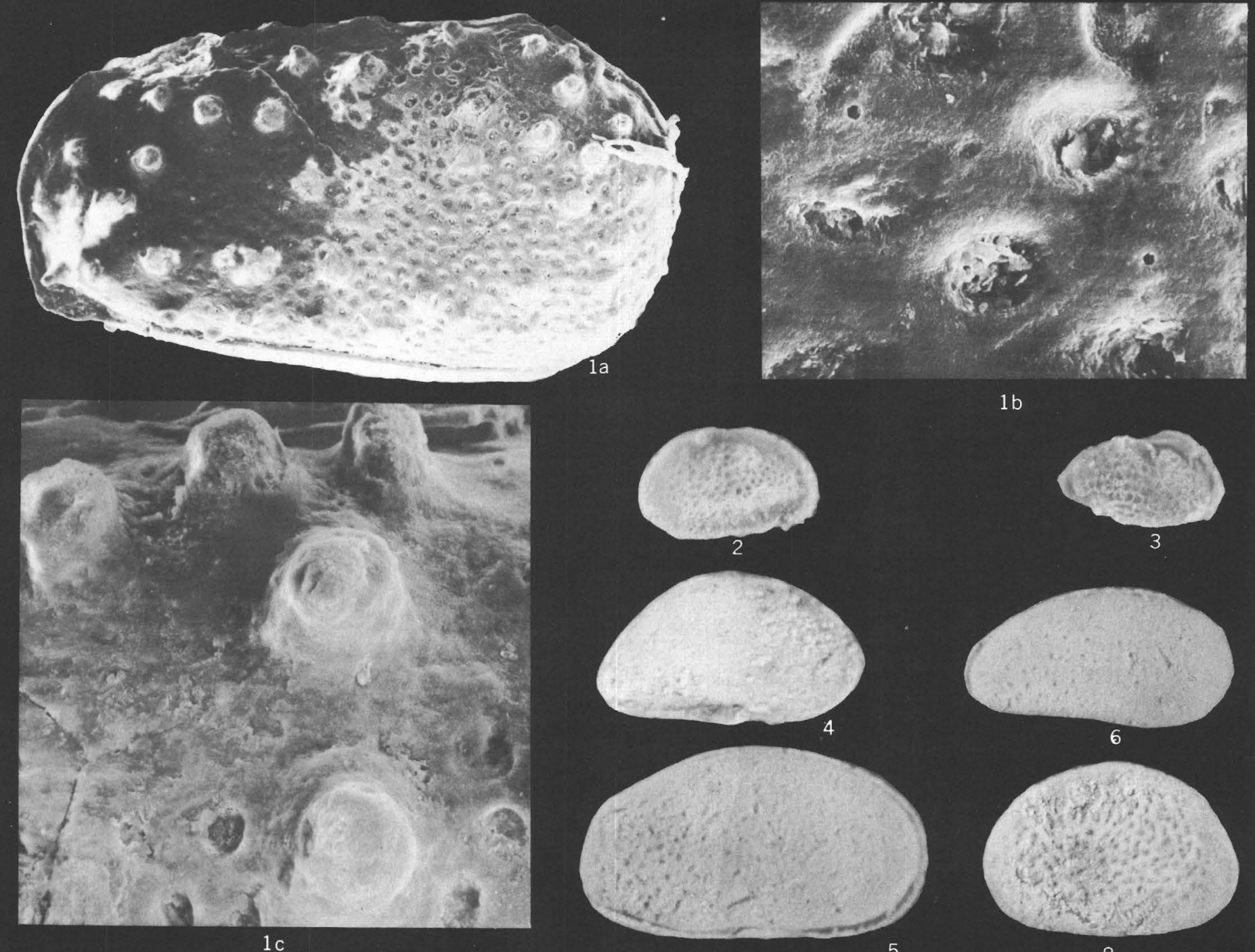

$1 b$
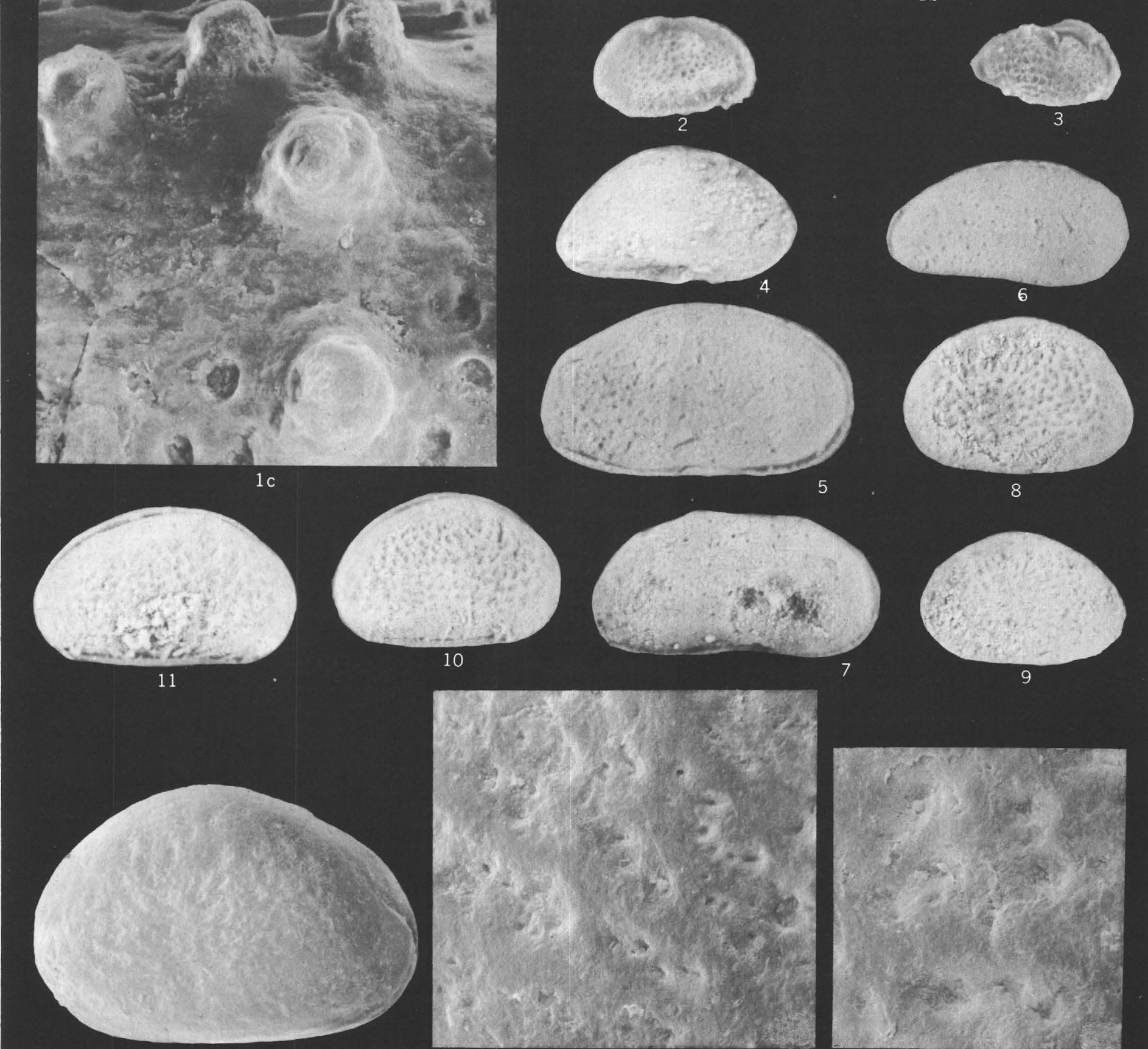


\section{PLATE 4}

Figures 1, 2. Asciocythere? migosa Swain and Brown, n. sp. (p. 24).

1. a, Left side paratype female shell, $\times 220 ; \mathrm{b}$, part of anterior surface, showing a few normal pores, $\times$ 1,100, NC-HY-OT-11, 5,016-5,026 feet, Unit G. USNM 177647.

2. a, Right side of paratype shell, $\times 110$; b, part of anterodorsal surface, $\times 1,100$, NC-HY-OT-11, 5,016-5,026 feet, Unit G. USNM 177648.

3-6. Asciocythere rotunda (Vanderpool) (p. 23).

3. Right side of shell, $\times 110$, NC-HY-OT-11, 5,416-5,426 feet, Unit G. USNM 177649.

4. Sieve plate structure, $\times 2,250$, NC-HY-OT-11, 4,426-4,436 feet, Unit F. USNM 177650.

5. Right side of male shell, $\times 52$, NC-HY-OT-11, 5,286-5,296 feet, Unit G. USNM 177651.

6. Left side of female? shell, $\times$ 52, NC-HY-OT-11, 5,286-5,296 feet, Unit G. USNM 177652.

7-10. Asciocythere macropunctata Swain (p. 23).

7. Right side of female shell, $\times$ 57, NC-HY-OT-11, 2,906-2,916 feet, Unit C. USNM 177653.

8. Dorsal view of male shell, $\times 56$, NC-HY-OT-1 1, 2,936-2,946 feet, Unit C. USNM 177654.

9. Right side of male shell, $\times 57$, NC-HY-OT-11, 2,906-2,916 feet, Unit C. USNM 177655.

10. a, Right side of shell, $\times 110$; b, sieve plate structure in dorsal part of shell, $\times 5,300$, NC-HY-OT-6, 2,780-2,790 feet, Unit E. USNM 177656. 


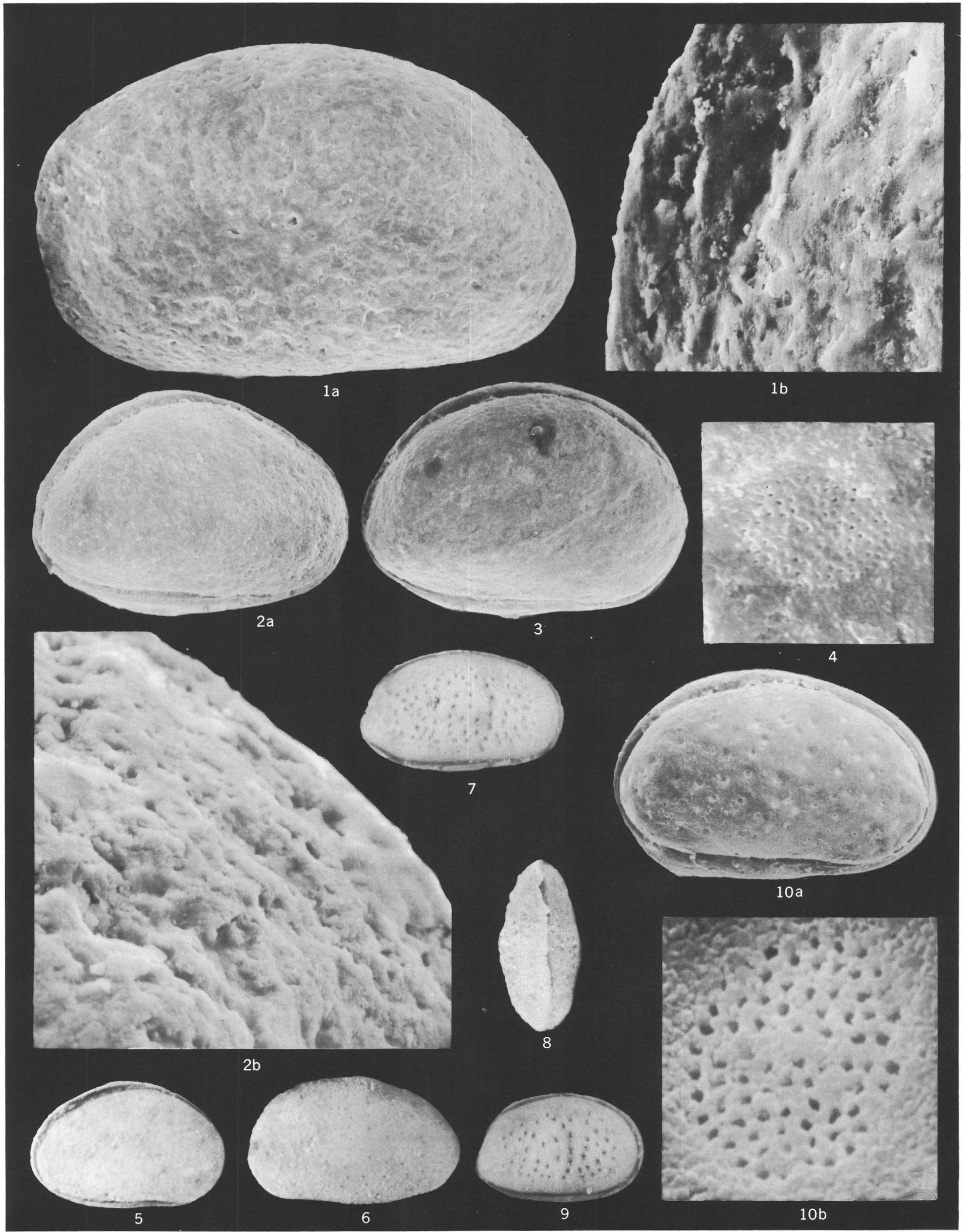




\section{PLATE 5}

Figures 1, 2. Asciocythere macropunctata Swain (p. 23).

1. Left side of shell, $\times 110$, NC-HY-OT-6, 2,780-2,790 feet, Unit E. USNM 177657.

2. a, Interior of left valve, $\times 110 ; b$, enlargement of anterior part of hinge margin (rotated clockwise as compared to its position in "a"), × 555, NC-HY-OT-6, 2,780-2,790 feet, Unit E. USNM 177658. 3, 5-7. Asciocythere elongata Swain and Brown, n. sp. (p. 22).

3. Right side of holotype female? shell, $\times$ 48, NC-HY-OT-11, 5,286-5,296 feet, Unit G. USNM 177638.

5. a, Left side of paratype male? shell, $\times 110 ; \mathrm{b}$, sieve plate structure of shell, $\times 5,500$, NC-HY-OT11, 5,386-5,396 feet, Unit G. USNM 177639.

6. a, Right side of paratype shell, $\times 102$; b, sieve plate structure in dorsal part of shell, $\times 5,000, \mathrm{NC}-$ HY-OT-11, 4,456-4,466 feet, Unit F. USNM 177640.

7. Ventral view of paratype shell, $\times 100$, NC-HY-OT-11, 4,456-4,466 feet, Unit F. USNM 177641.

4. Ovocytheridea? sp. (p. 25).

Right side of shell, $\times 56$, NC-HY-OT-11, 5,016-5,026 feet, Unit G. USNM 177659 . 


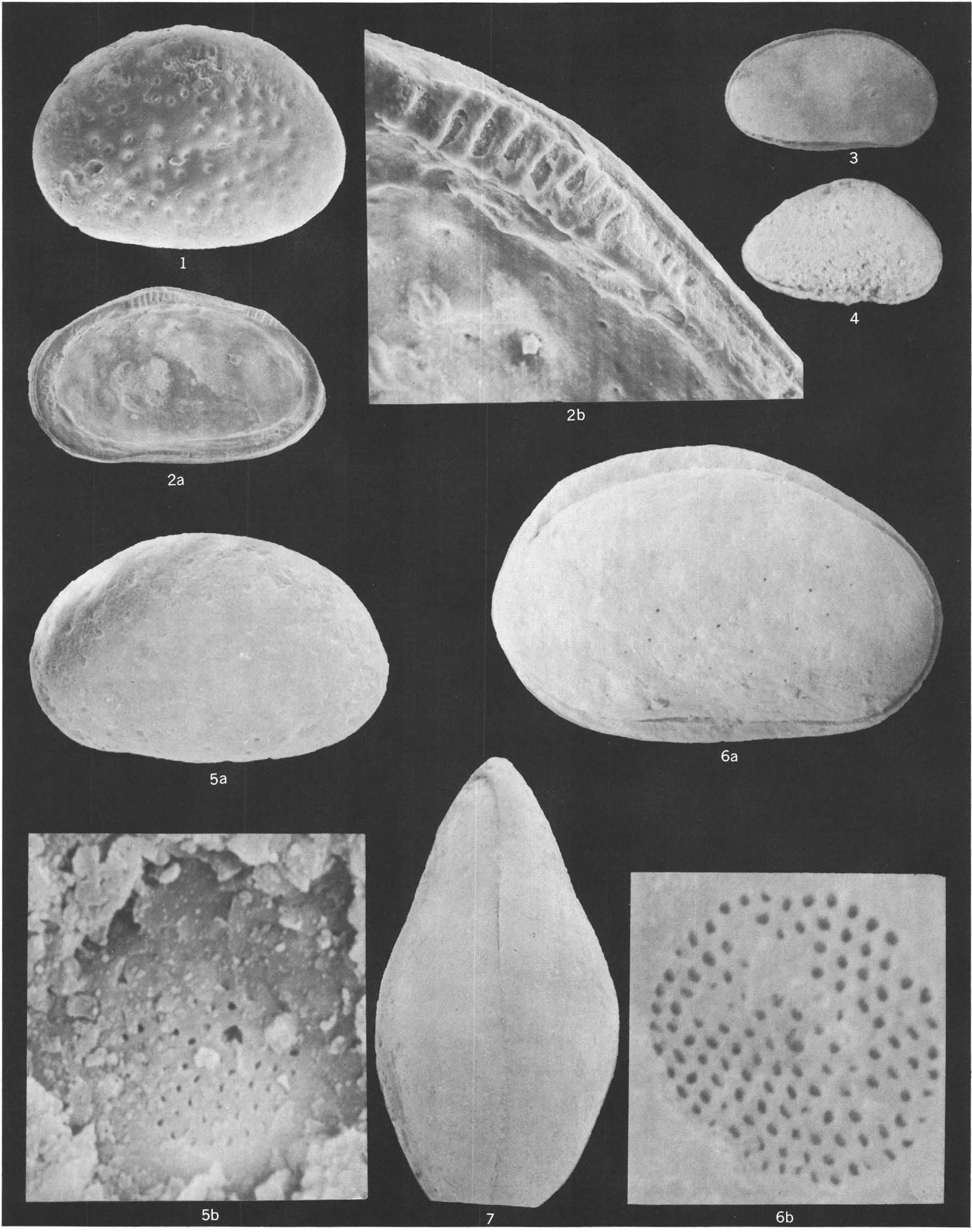




\section{PLATE 6}

Figures 1-3. Fossocytheridea lenoirensis Swain and Brown (p. 25).

1. a, Exterior of right valve, $\times 115$; b, external opening of normal pore and sieve plate, $\times 5,250$. NCCAR-OT-7, 3,230-3,240 feet, Unit F. USNM 177660.

2. a, Interior of right valve, $\times 104 ; \mathrm{b}$, anterior part of hinge, $\times 1,040$. NC-HAL-T-13, $125-130$ feet, Unit F. USNM 177661.

3. Right side of shell, $\times$ 90, NC-HAL-T-13, 125-130 feet, Unit F. USNM 177662.

4-7. Schuleridea anterofossulata Swain and Brown, n. sp. (p. 27).

4. Right side of paratype shell, $\times 60$, NC-DA-OT-12, 6,096-6,106 feet, Unit G. USNM 177663 .

5. Dorsal view of a paratype shell, $\times$ 62, NC-DA-OT-12, 6,096-6,106 feet, Unit G. USNM 177664.

6. Right side of holotype shell, $\times 57$, NC-DA-OT-11, 4,606-4,616 feet, Unit G. USNM 177665.

7. Right side of paratype shell, $\times 59$, NC-DA-OT -11, 4,606-4,616 feet, Unit G. USNM 177666.

8, 9. Schuleridea hatterasensis Swain (p. 28).

8. Right side of shell, $\times 60$, NC-DA-OT-12, 5,416-5,426 feet, Unit G. USNM 177669.

9. a, Right side of shell, $\times 110 ; \mathrm{b}$, part of median surface of shell, $\times 2,200$, showing labyrinthic nature of shell surface, several surface pits and a normal pore, in lower right hand area, NC-DA-OT-12, 5,416-4,526 feet, Unit G. USNM 177670.

10. Schuleridea? lacustris Swain (p. 28).

Left side of shell, $\times$ 62, NC-DA-OT-13, 5,687-5,697 feet, Unit H. USNM 177668 . 


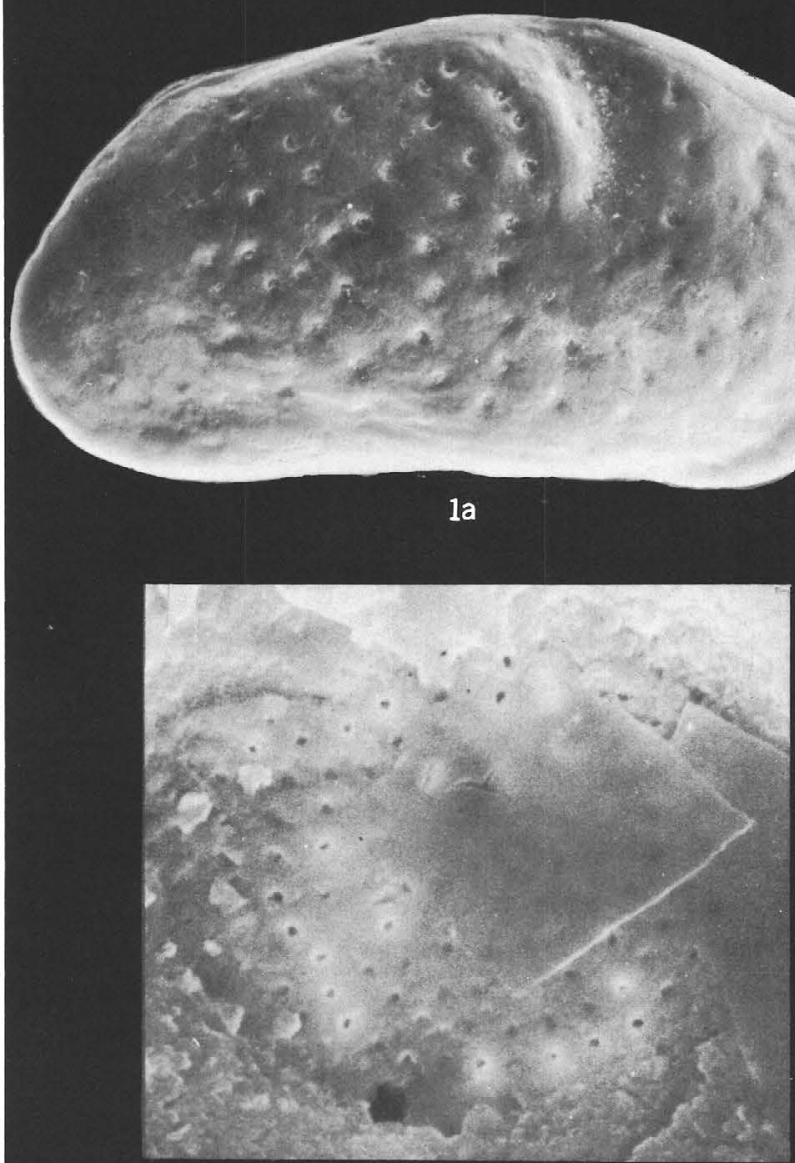

1b
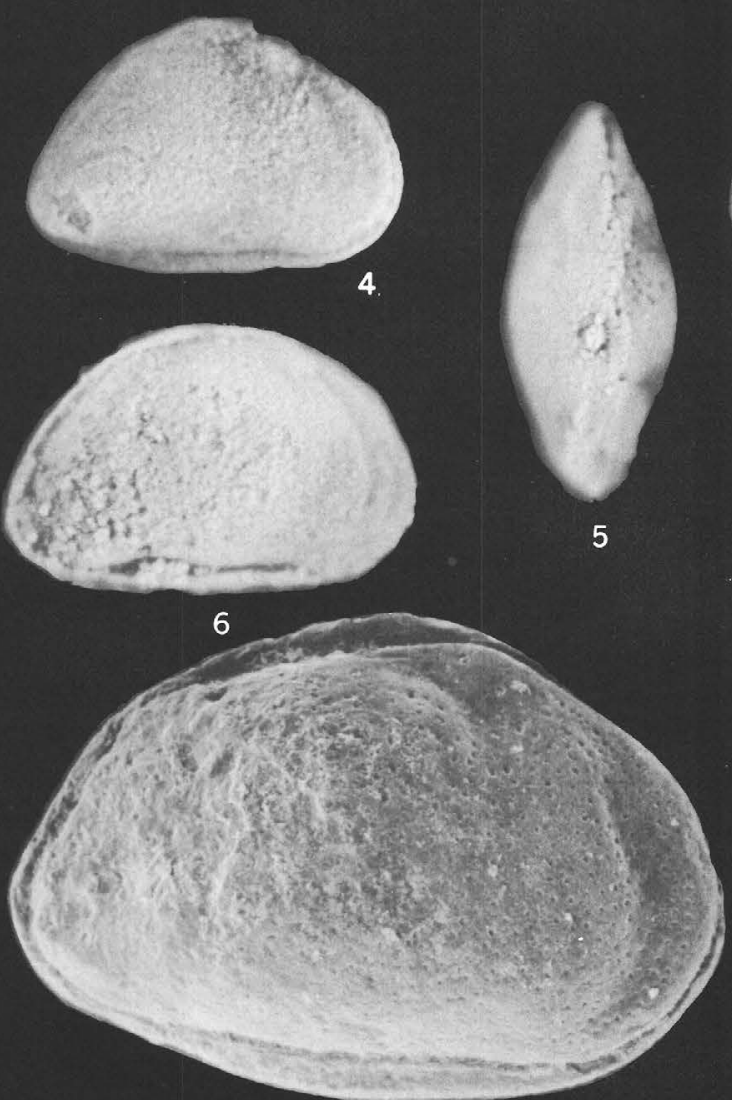

$9 a$
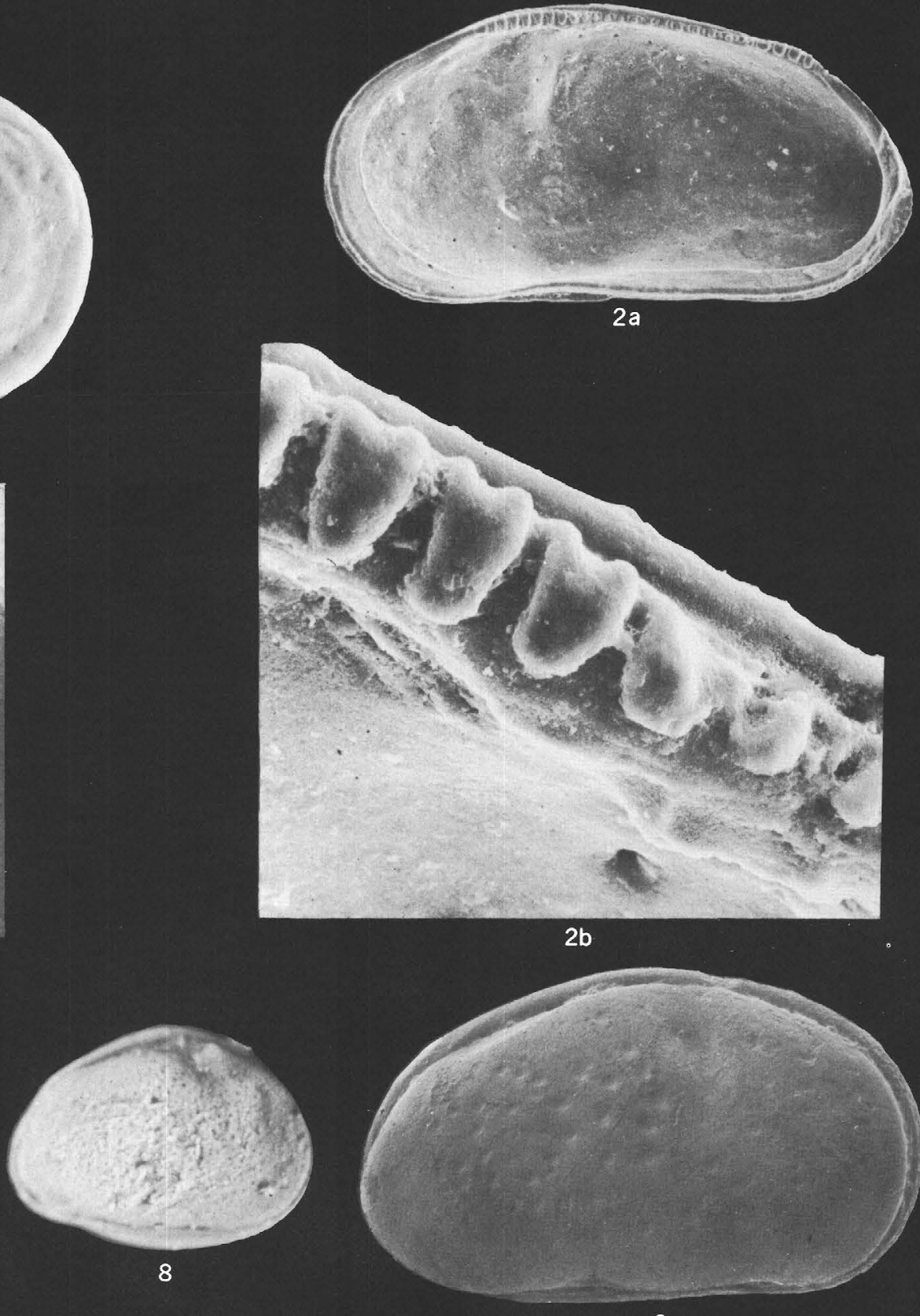

$2 b$
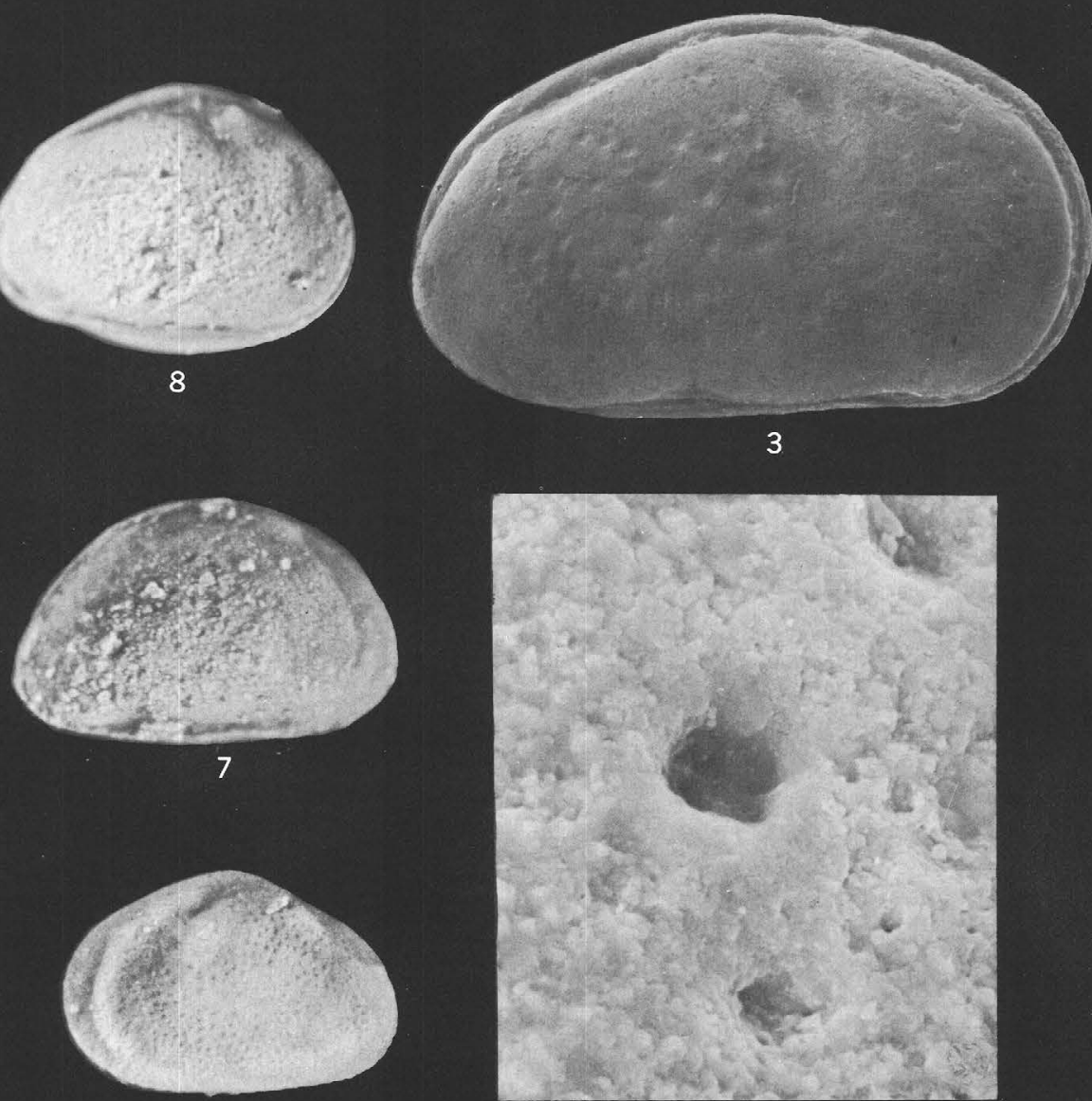

10

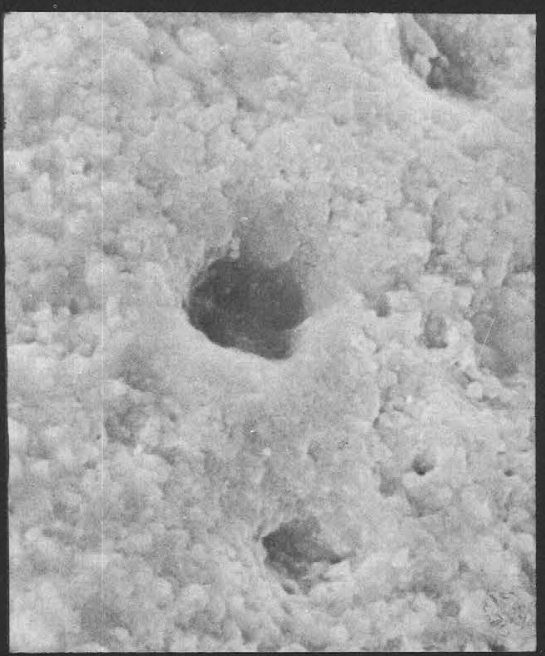

$9 b$ 


\section{PLATE 7}

Figure 1. Schuleridea? sp. (p. 28).

Right side of shell, $\times$ 55, NC-HY-OT-11, 3,756-3,766 feet, Unit E. USNM 177667.

2. Paraschuleridea twifordensis Swain and Brown, n. sp. (p. 30).

Right side of holotype shell, $\times$ 63, NC-DA-OT-14, 4,749-4,759 feet, Unit H. USNM 177671.

3. Paraschuleridea postumbonata Swain and Brown, n. sp. (p. 30).

Right side of holotype shell, $\times$ 60, NC-DA-OT-12, 6,626-6,636 feet, Unit G. USNM 177672.

4. Paraschuleridea curta Swain and Brown, n. sp. (p. 29).

Right side of holotype shell, $\times$ 57, NC-DA-OT-13, 5,697-5,707 feet, Unit H. USNM 177673.

5-7, 9. Fabanella tumidosa (Swain) (p. 32).

5. a, Right side and, b, dorsal views of a shell, $\times 65$, NC-CAR-OT-7, 4,680-4,690 feet, Unit H. USNM 177675 .

6. Left side of a shell, $\times 65, \mathrm{NC}-\mathrm{CAR}-\mathrm{OT}-7,4,680-4,690$ feet, Unit H. USNM 177676.

7. a, Left side and, b, dorsal views of a shell, $\times 65$, NC-CAR-OT-7, 4,680-4,690 feet, Unit H. USNM 177677.

9. a, Left side of shell, $\times 112 ; \mathrm{b}$, part of anteroventral surface, $\times 560$; $\mathrm{c}$, enlargement of part of median surface, $\times$ 2,210, NC-HY-OT-11, 5,396-5,406 feet, Unit G. USNM 177678.

8. Fabanella sp. (p. 32).

Right side of shell, $\times$ 60, NC-HY-OT-11, 5,316-5,326 feet, Unit G. USNM 177674.

10. Fabanella leguminoidea (Swain) (p. 31).

Right side of presumed female shell, $\times 100$, NC-DA-OT-11, 4,426-4,436 feet, Unit G. USNM 177680.

11. Fabanella lanceolata (Swain) (p. 31).

Right side of shell, $\times$ 100, NC-DA-OT-11, 4,426-4,436 feet, Unit G. USNM 177679. 

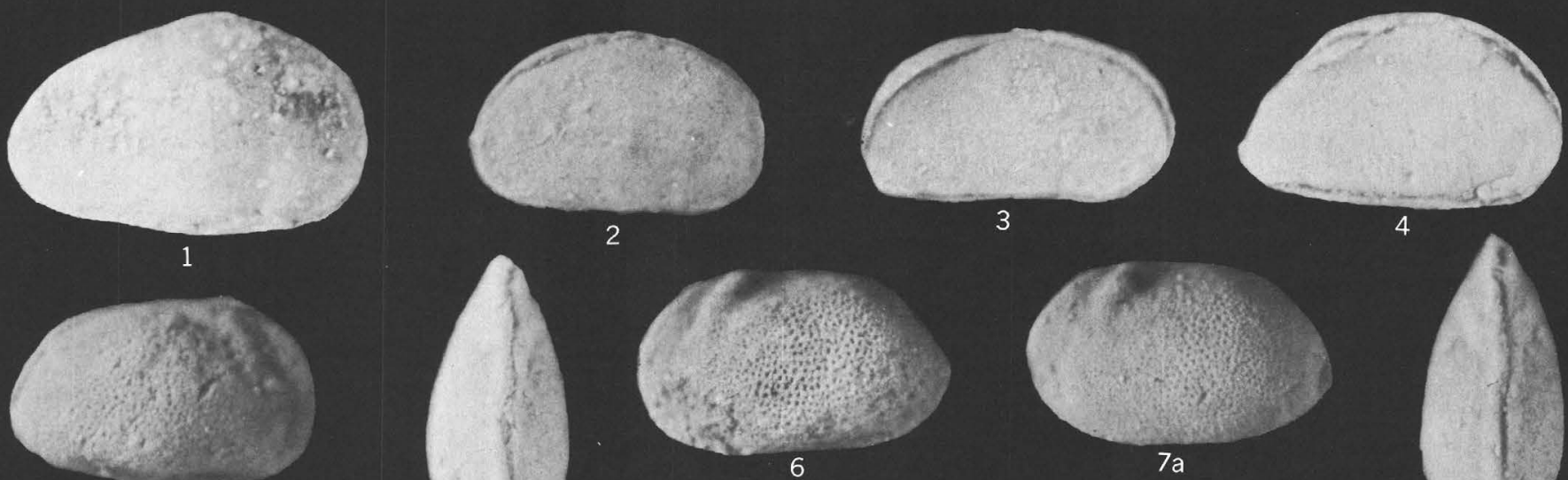

$5 a$
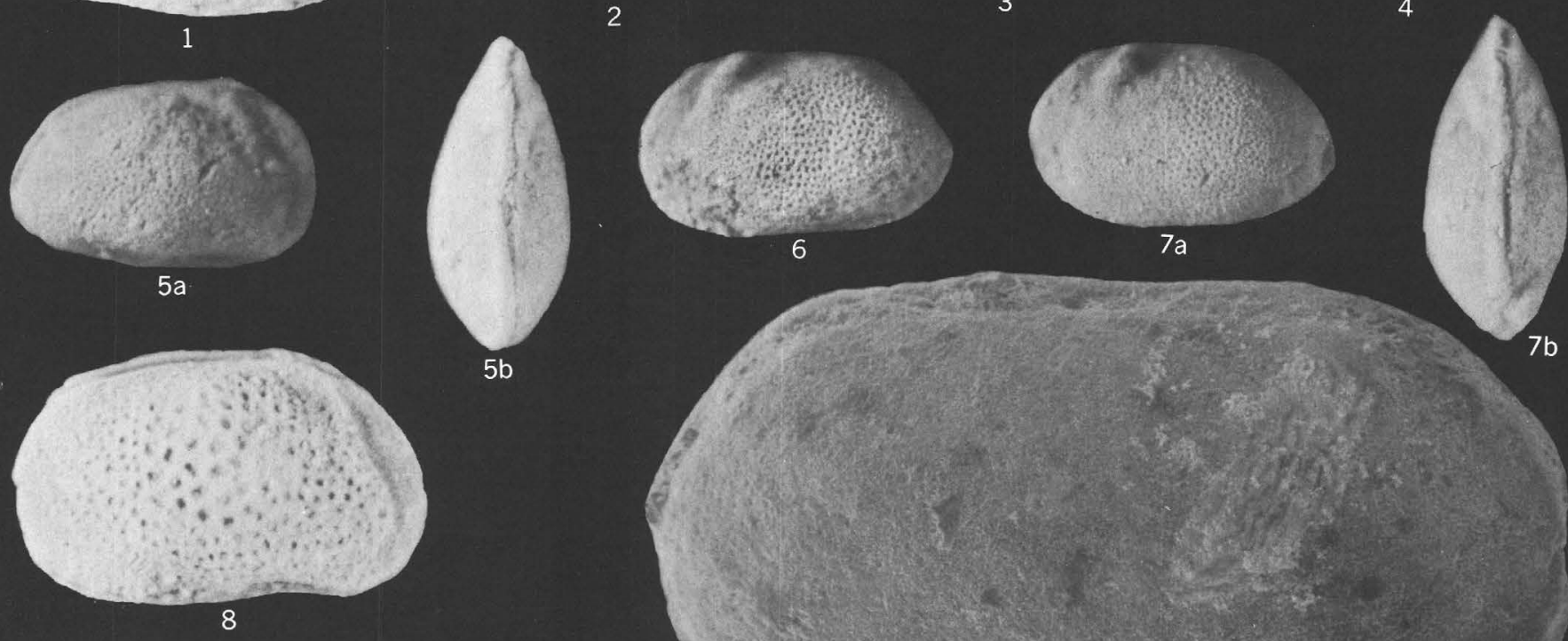

6

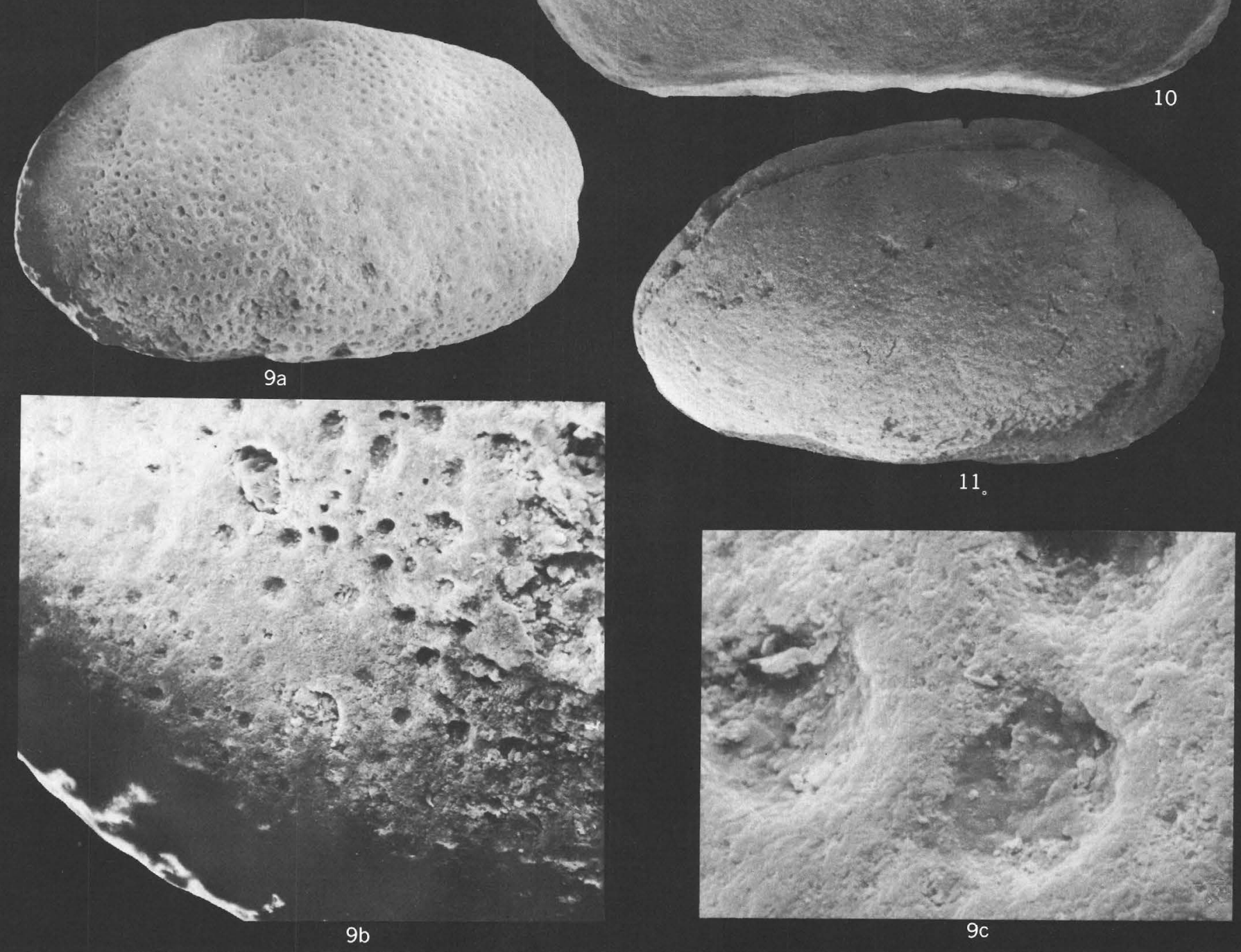

SCHULERIDEA?, PARASCHULERIDEA, AND FABANELLA 


\section{PLATE 8}

Figures 1, 2. Metacytheropteron? bicostatum Swain and Brown, n. sp. (p. 34).

1. Right side of paratype shell having particles of adhering matrix, $\times 56$, NC-DA-OT-12, 4,696-4,706 feet, Unit F. USNM 177681.

2. Left side of holotype shell, $\times 56$, NC-CUR-OT-12, 4,338-4,348 feet, Unit H. USNM 177682.

3. Otocythere sp. (p. 35).

a, Right side and, b, dorsal view of shell, $\times$ 58, NJ-CM-OT-1, 6,038-6,048 feet, Unit H. USNM 177683.

4, 5. Eocytheropteron trinitiensis (Vanderpool) (p. 36).

4. Left side of shell, $\times 200$, NC-DA-OT-12, 5,386-5,396 feet, Unit G. USN.M 177684.

5. Dorsal view of shell, $\times 60$, NC-DA-OT-12, 5,386-5,396 feet, Unit G. USNM 177685.

6. Eucytherura? sp. (p. 38).

Left side of shell, $\times$ 60, NC-HY-OT-11, 4,456-4,466 feet, Unit F. USNM 177686.

7. Juvenix sp. (p. 38).

a, Exterior and, b, interior views of left valve, $\times 59$, NC-CAR-OT-5, 5,252-5,262 feet, Unit H. USNM 177687.

8-14, 22, 23. Hutsonia collinsensis collinsensis Swain and Brown, n. sp., n. subsp. (p. 41).

8. Right side of immature paratype shell, $\times 59$, NC-CUR-OT-12, 4,338-4,348 feet, Unit H. USNM 177688.

9. Right side of male holotype shell, $\times 59$, NC-CUR-OT-12, 4,318 4,328 feet, Unit H. USNM 177689.

10. Right side of female paratype shell, $\times 59$, NC-DA-OT-11, 4,606-4,616 feet, Unit G. USNM 177690 .

11. Right side of female paratype shell, $\times 59$, NC-DA-OT-11, 4,596-4,606 feet, Unit G. USNM 177691.

12. Left side of immature paratype shell, $\times 59$, NC-DA-OT-13, 5,687-5,697 feet, Unit H. USNM 177692 .

13. Left side of immature paratype shell, $\times 59$, NC-CUR-OT-12, 4,328-4,338 feet, Unit H. USNM 177693.

14. Right side of female paratype shell, $\times 59$, NC-CUR-OT-12, 4,328-4,338 feet, Unit H. USNM 177694 .

22. Right side of shell, $\times 60$, having subdued surface ornamentation, NC-DA-OT-12, 6,626-6,636 feet, Unit G. USNM 177695.

23. a, Left side of shell, $\times 110$; b, enlargement of part of anteroventral surface, showing a normal pore, $\times 2,200$, NC-DA-OT-11, 4,596-4,606 feet, Unit G. USNM 177696.

15. Hutsonia collinsensis attenuata Swain and Brown, n. sp., n. subsp. (p. 42).

Right side of holotype shell, $\times$ 60, NC-DA-OT-13, 5,697-5,707 feet, Unit H. USNM 177697.

16, 17. Hutsonia collinsensis micropunctata Swain and Brown, n. sp., n. subsp. (p. 42).

16. Right side of paratype shell, $\times 70$, NC-DA-OT-12, 6,626-6,636 feet, Unit G. USNM 177698.

17. Left side of holotype shell, $\times$ 70, NC-DA-OT-12, 7,106-7,116 feet, Unit H. USNM 177699.

18. Hutsonia collinsensis subsp. (p. 43).

Left side of shell, $\times 60$, NC-CUR-OT-12, 4,318-4,328 feet, Unit H. USNM 177700.

19. Hutsonia? cf. H.? microrugosa Swain (p. 43).

Right side of shell, $\times 62$, that is more punctate and lacks the narrow mid-ventral ridge of the holotype,

NC-DA-OT-12, 5,756-5,766 feet, Unit G. USNM 177707.

20, 21. Hutsonia? sp., immature (p. 44).

20. Right and, 21 , left sides of two specimens, $\times 60$, not referable to described species, introduced here for comparison with other Hutsonias. Dorcheat Member of Schuler Formation, Upper Jurassic, Morgan No. 2 Smith well, Bossier Parish, La., core 5,045-5,063 feet. 20, USNM 177708. 21, USNM 177709.

24-26. Hutsonia blandoidea Swain and Brown, n. sp. (p. 39).

24. Right side of paratype shell, $\times$ 65, NC-DA-OT-13, 5,697-5,707 feet, Unit H. USNM 177701.

25. Dorsal view of paratype shell, $\times 65$, (same specimen as pl. 9, fig. 2), NC-CAR-OT-7, 4,680-4,690 feet, Unit H. USNM 177702.

26. Dorsal view of holotype shell, $\times 65$, (same specimen as pl. 9, fig. 3), NC-CAR-OT-7, 4,680-4,690 feet, Unit H. USNM 177703. 


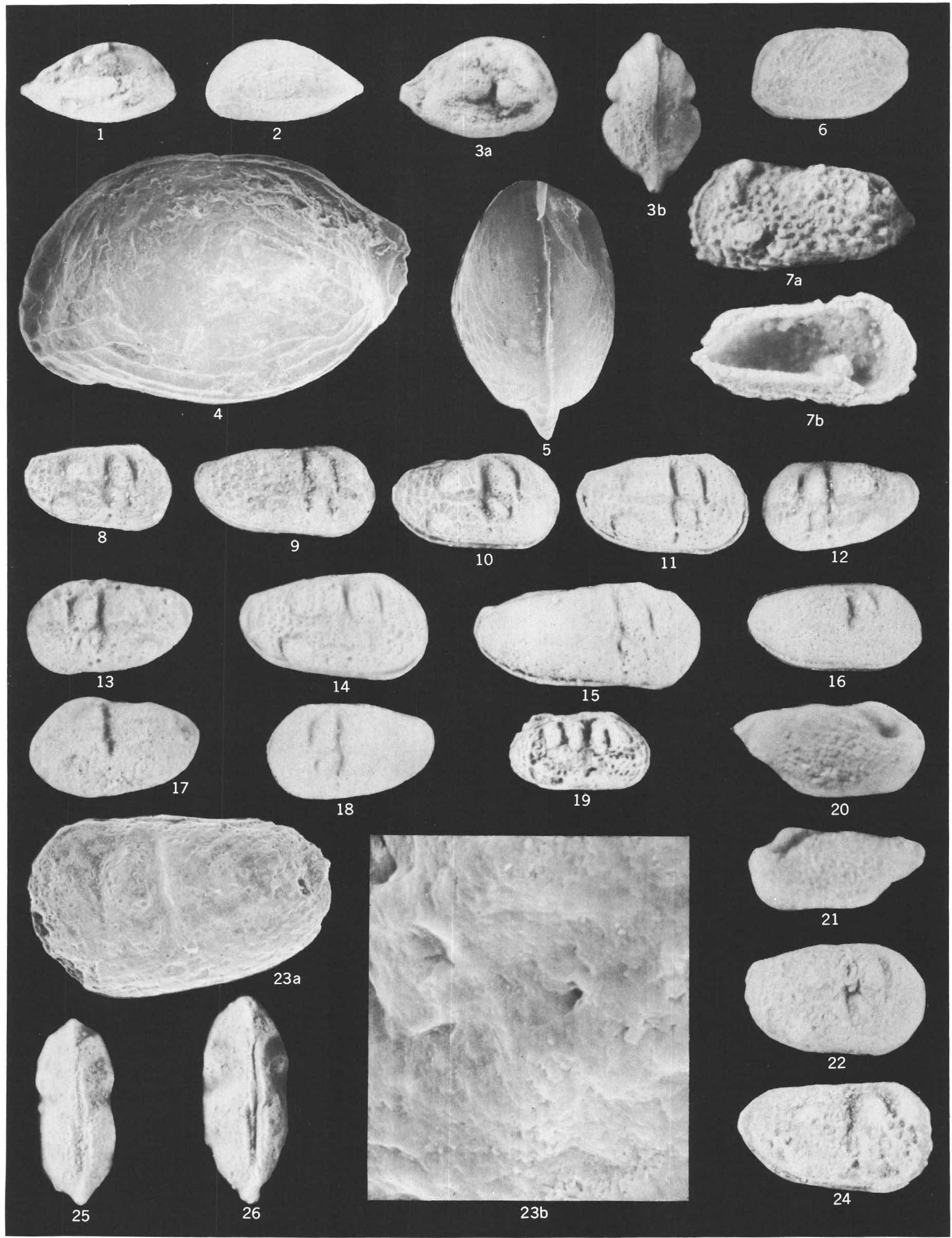

METACYTHEROPTERON?, OTOCYTHERE, EOCYTHEROPTERON, EUCYTHERURA?, JUVENIX, HUTSONIA, AND HUTSONIA? 


\section{PLATE 9}

Figure 1. Hutsonia sp. (p. 43).

Left side of shell, $\times$ 57, NC-CAR-OT-7, 4,680-4,690 feet, Unit H. USNM 177706.

2-5. Hutsonia blandoidea Swain and Brown, n. sp. (p. 39).

2. Left side of paratype shell, $\times 65$, NC-CAR-OT-7, 4,680-4,690 feet, Unit H. USNM 177702.

3. Right side of holotype shell, $\times 65$, NC-CAR-OT-7, 4,680-4,690 feet, Unit H. USNM 177703 .

4. Left side of poorly preserved shell, $\times$ 65, NC-D A-OT-13, 5,697-5,707 feet, Unit H. USNM 177704.

5 . a, Left side of paratype shell, $\times 110$; b, enlargement of part of anteromedian surface, $\times 1,100, \mathrm{NC}-$ DA-OT-11, 4,776-4,786 feet, Unit H. USNM 177705.

6. Protocythere sp. aff. P. inornata Kaye (p. 44).

Right side of shell, $\times 60, \mathrm{NC}-\mathrm{DA}-\mathrm{OT}-12,6,676-6,686$ feet, Unit G. USNM 177711.

7, 8. Protocythere aff. P. aptensis Oertli (p. 44).

7. Left side of shell, $\times 60$, NC-HY-OT-11, 4,396-4,406 feet, Unit F. USNM 177712.

8. Right side of shell, $\times 114$, NC-DA-OT-14, 5,009-5,019 feet, Unit H. USNM 177713.

9. Protocythere? sp. 1 (p. 45).

Left side of shell, $\times$ 54, NC-HY-OT-11, 4,426-4,436 feet, Unit F. USNM 177710 .

10. Cythereis sp. aff. C. lamplughi Kaye (p. 47).

Right side of shell, $\times$ 60, NC-DA-OT-12, 6,276-6,286 feet, Unit G. USNM 177621.

11. Klieana? sp. (p. 46).

a, Exterior $(\times 55)$ and, b, interior $(\times 60)$ views of left valve, NJ-CM-OT-1, 4,328-4,338 feet, Unit G. USNM 177714.

12, 13. Taxodiella sp. (p. 49).

12. Left side of shell, $\times 56$, NC-CUR-OT-12, 4,298-4,318 feet, Unit H. USNM 177622 .

13. Exterior view of right valve, $\times$ 54, NC-CUR-OT-12, 4,298-4,318 feet, Unit H. USNM 177623.

14. Mandelstamia? sp. (p. 49).

Right side of shell, $\times$ 60, NC-DA-OT-12, 6,536-6,546 feet, Unit G. USNM 177624.

15. Isocythereis? sp. (p. 48).

a, Right side and, b, dorsal views of shell, $\times$ 64, NJ-CM-OT-1, 3,748-3,758 feet, Unit G. USNM 177625 .

16. Cythereis sp. (p. 48).

Left side of shell, $\times$ 60, NC-DA-OT-12, 6,326-6,336 feet, Unit G. USNM 177626.

17-19. Cythereis cf. C. dentonensis Alexander (p. 47).

17. a, Left side and, b, dorsal views of shell, $\times 65$, NJ-CM-OT-1, 3,418-3,428 feet, Unit F. USNM 177627.

18. Ventral view of shell, $\times 65$, NJ-CM-OT-1, 3,418-3,428 feet, Unit F. USNM 177628 .

19. Right side of shell, $\times 65$, NJ-CM-OT-1, 3,418-3,428 feet, Unit F. USNM 177628. 


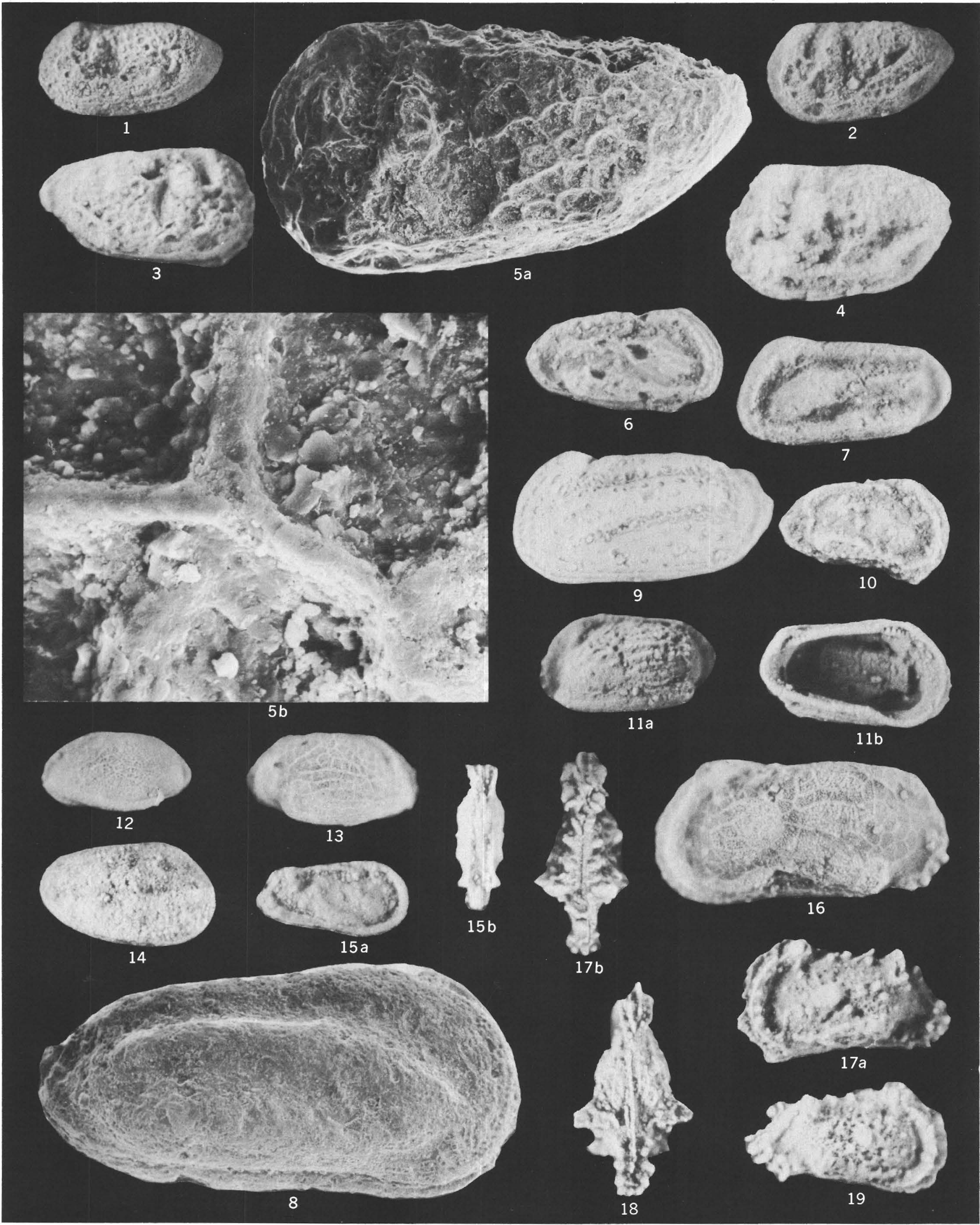


